\title{
SOCIEDADES INDÍGENAS Y CONOCIMIENTO ANTROPOLÓGICO. AYMARAS Y ATACAMEÑOS DE LOS SIGLOS XIX Y XX
}

\author{
INDIGENOUS SOCIETIES AND ANTHROPOLOGICAL ADVANCES. THE \\ AYMARA AND ATACAMEÑO PEOPLES OF THE XIXth AND XXth CENTURIES
}

\author{
Hans Gundermann Kröll ${ }^{1}$ y Héctor González Cortez ${ }^{2,3}$
}

\begin{abstract}
En este trabajo se analiza el desarrollo del conocimiento antropológico producido sobre los aymaras y atacameños del norte de Chile, desde mediados del S. XIX a la actualidad, relacionando estos aportes con el contexto histórico y la etapa de evolución de la disciplina correspondiente al momento en que se generan. Se termina con un balance del estado actual del conocimiento sobre estos pueblos, señalando avances, carencias y desafíos futuros.
\end{abstract}

Palabras claves: conocimiento antropológico, historia de la antropología, aymaras, atacameños, norte de Chile.

We present an historical account of advance in anthropological research on the Aymara and Atacameño peoples of Northern Chile from the middle of the XIXth century to the present. This account is contextualized historically in tandem with the evolution of the discipline at the moments in which knowledge was generated. This study ends with an analysis of current knowledge of these peoples, pointing out progress, studies still lacking, and challenges for future investigation.

Key words: Aymara, Atacameño, Northern Chile, anthropological historical review.

Este trabajo es una aproximación al desarrollo del conocimiento antropológico sobre aymaras y atacameños del norte de Chile, desde mediados del S. XIX a la actualidad. No se abordan las transformaciones económicas, sociales y culturales que han experimentado estos pueblos, sino los tipos de conocimientos generados sobre estos pueblos por distintos investigadores a lo largo de este período, relacionando estos aportes con el contexto histórico y la etapa de evolución de la disciplina correspondiente al momento en que se generan.

El conocimiento producido sobre aquellos sujetos sociales del norte de Chile que son genéricamente considerados bajo el rótulo de indígenas es relativo a varias condiciones. Desde luego, al contexto histórico en que se elabora, que condiciona vínculos específicos de ese conocimiento con propósitos y prácticas preferentes de pertinencia o cambio social que varían en el tiempo. También es relativo al desarrollo mismo de la disciplina o de otras afines que también se han ocupado de estos sujetos, en términos de las distintas orientaciones teóricas y metodológicas que subyacen a la construcción del conocimiento antropológico en determinados momentos.

No se trata, entonces, de una mera acumulación sucesiva de conocimientos donde cada nuevo logro viene, por así decirlo, a sumar un nuevo peldaño o componente de una trayectoria u obra que se completa progresivamente. Lo que sabemos hoy se informa, sin duda, de lo precedente y surge del esfuerzo por denotar una realidad, pero ese resultado está mediado siempre por el sello impuesto por los sujetos que formulan ese conocimiento, los límites impuestos por las culturas institucionales, los procedimientos, los objetos objetivos de conocimiento preferentes o establecidos, en suma, por sus escuelas y tradiciones (Alexander 1990). Éstas no siempre y necesariamente se suceden las unas a las otras, sino que, provistas a veces de una tenacidad centenaria, pueden coexistir por largo tiempo. Incluso, cuando no es ese el caso, sí lo es el hecho de que temas, supuestos, criterios y tecnología-además de los prejuicios o la rigidez e inercia mentales- pueden circular y permanecer más allá de sus formaciones de origen.

\footnotetext{
1 Instituto de Investigaciones Arqueológicas y Museo, Universidad Católica del Norte, San Pedro de Atacama, Chile. hgunder@ucn.cl

2 Departamento de Antropología, Universidad de Tarapacá, Arica, Chile, hgonzale@uta.cl

3 Centro de Investigaciones del Hombre en Desierto (CIHDE), Arica, Chile.
} 
Pero este saber es también performativo, pues contribuye a constituir aquello que designa (Bourdieu 1999, 2001). Sin ir más lejos, ocurre con los propios sujetos étnicos cuando existen condiciones sociales y políticas para que ello suceda, y la propia designación de los grupos sociales que acaparan nuestra atención, como "aymaras" y "atacameños", es un buen ejemplo de lo señalado. Por tanto, el conocimiento antropológico del que se ocupa este trabajo no sólo se especifica en su relación con realidades sociales que se modifican, con la pluralidad de sus orígenes o en la asincronía de su presencia, sino que también, de manera más compleja, por su propia eficiencia social.

Para el desarrollo de este trabajo se ha seguido una periodificación tentativa, que comienza con la etapa de los precursores (1860-1950) y continúa con la fase de profesionalización de la disciplina (1950 a la actualidad). Dadas las graves consecuencias que tuvo el golpe militar de 1973 para el desarrollo de la antropología en particular y las ciencias sociales en general, este último período se ha subdividido en tres etapas: antes del quiebre democrático, dictadura y retorno a la democratización del país. Este recuento termina con un balance del estado actual del conocimiento sobre aymaras y atacameños, relevando avances y vacíos, pero también desafíos. En las conclusiones, finalmente, se sintetizan los distintos sujetos que la antropología del norte ha "postulado" o "construido" como objetos de estudio, y se proponen algunos principios y criterios para potenciar una práctica antropológica regional de cara al siglo XXI.

\section{La Mirada de los Precursores (1860-1950)}

Entre alrededor de 1860 y finales de la década de 1940, los indígenas del norte del país son incluidos en variados estudios. Sus autores pueden ser considerados como los precursores del conocimiento antropológico de grupos hoy calificados como aymaras y atacameños. Generan información antropológica relevante desde formaciones profesionales e intereses de conocimiento heterogéneos. Todo ello en momentos en que la disciplina todavía no se ha institucionalizado académicamente, en términos de la existencia de centros de investigación y del funcionamiento de carreras universitarias dedicadas a la formación de antropólogos profesionales. El marco donde se genera conocimiento antropológico durante estas décadas es variado.

\section{El indígena en el marco de la evaluación de los recursos y la definición de las fronteras nacionales}

La delimitación de las fronteras nacionales o el reconocimiento de territorios en conflicto durante el S. XIX e inicios del S. XX generaron exploraciones, trabajos e investigaciones financiadas por el Estado chileno ( $\mathrm{y}$ antes por el peruano), destinadas a relevar la geografía de la zona y evaluar sus recursos naturales y económicos. Junto con ello, se levanta registro de la situación demográfica, social y política de la población. Geógrafos, agrimensores e ingenieros entregan informes a las autoridades, algunos de los cuales son publicados en imprentas regionales y otros en metropolitanas, que aportan diversas notas sobre las poblaciones andinas, incluyendo datos acerca de pueblos y asentamientos, población, actividades económicas, estado "social", prácticas y costumbres. Los autores más importantes son Rodulfo Phillipi, con su reconocimiento del despoblado de Atacama por encargo del gobierno de Chile (Phillipi 1860); Mariano Felipe Paz Soldán, peruano, que publica en vísperas de la guerra y quizá porque ésta se avecinaba (Paz Soldán 1865, 1877); Alejandro Bertrand, con sus informes geográficos y exploraciones de Tacna, Arica, Tarapacá y Atacama (Bertrand 1879a, 1879b, 1885a, 1885b); Francisco Risopatrón (1890), que publica el diccionario geográfico de Tacna y Tarapacá; Francisco San Román (1896) que explora el desierto y la cordillera atacameña; Luis Risopatrón con sus expediciones fronterizas en Tarapacá y Atacama (Risopatrón 1906, 1910, 1918; también su diccionario geográfico de 1924).

\section{El indígena en el marco de las misiones de exploración científica}

La zona también fue recorrida por extranjeros que, aunque pudieron estar ligados a intereses estatales o privados, estaban más interesados en la exploración de territorios desconocidos o problemáticas de relevancia científica general ${ }^{1}$. Un par de ellos desarrolla investigaciones históricas, geográficas y arqueológicas, incluyendo noticias, comentarios o descripciones de las poblaciones etnográficas del norte de Chile. Siguiendo las tendencias de la época, abundan reconstrucciones históricas fundadas en premisas difusionistas y evolucionistas. Se trata de Isaiah Bowman (1942 [1924]) $)^{2}$ ), con su descripción geográfica y de recursos de Atacama, 
Tarapacá meridional y la pampa salitrera, donde se encuentran datos sobre la población atacameña y aymara; y de Eric Boman (1908), arqueólogo sueco, miembro de varias misiones científicas, quien realiza descripciones de los indios de la puna de Atacama, además de arqueología, y concreta una de las primeras etnografías atacameñas modernas con su descripción de Susques (localidad de la Provincia de Atacama que por ese entonces ya pertenecía a Argentina) $)^{2}$.

\section{Los indígenas en la construcción de la historia nacional}

Coincidiendo con los avances en el conocimiento de la prehistoria mundial, las sociedades chilenas del pasado también empiezan a ser importantes para el país, no sólo desde un punto de vista científico, sino también para la construcción de una historia nacional. Aparece un grupo de profesionales interesados en el origen y distribución de los grupos indígenas, sus costumbres y rasgos culturales. La antropología ya no es una actividad tangencial o circunstancial, sino una preocupación científica con importancia política. Pero, a diferencia de Boman que desarrolla una etnografía profesional, su principal preocupación es histórica. Son personas estrechamente vinculadas a las sociedades científicas de la época, a través de las cuales difunden sus conocimientos. En el norte del país intentan reconstrucciones históricas del origen, poblamiento y distribución de aymaras, atacameños y changos, así como caracterizaciones de su tecnología, actividades productivas y organización social. Todo ello con apego a una terminología derivada de las tesis evolucionistas y difusionistas, corrientes por aquella época. Sus intereses son primariamente científicos; pero sus resultados adquieren también un sentido político. Su balance de la situación del indígena nortino de entonces señala su completa integración (changos) o la presencia de escasos supervivientes y en franco proceso de asimilación (aymaras y atacameños). Entre estos científicos destacan Max Uhle, contratado por el gobierno chileno a principios de siglo, quien realiza trabajos de arqueología y reconstrucciones históricas considerando los pueblos del presente, de los que entrega algunos antecedentes (Uhle 1918, 1919, 1922); Tomás Guevara (1925-29) que los considera en su historia chilena prehispánica; y Ricardo Latcham $(1910,1915,1928,1929,1938)$ que reúne y presenta información etnográfica y arqueológica. Se pueden asimilar a este grupo los aportes de estudiosos anteriores, como José Toribio Medina con su obra general sobre los pueblos aborígenes chilenos (Medina 1882) y una específica de recopilación bibliográfica sobre las lenguas quechua y aymara (Medina 1930); Emilio Vaïsse, Félix Hoyos y Aníbal Echeverría, con su recopilación de voces cunza o atacameñas (Vaïsse et al. 1896); y otro posterior, Carlos Keller, que edita el censo económico de la provincia de Arica de 1942, con abundante información socio-demográfica y económica sobre los poblados interiores de población aymara (Keller 1946) ${ }^{3}$.

\section{El indígena en la reconstrucción histórica regional}

El indígena también se hace presente en algunos historiadores regionales y eclesiásticos, cuyos intereses manifiestos se limitan al conocimiento histórico regional. Entre ellos se encuentran Vicente Dagnino, quien escribe acerca del Corregimiento de Arica (Dagnino 1909) y sobre la localidad de Tacna (Dagnino 1910); y los peruanos: Rómulo Cúneo Vidal ${ }^{4}$, acerca de las poblaciones indígenas coloniales regionales (Cúneo Vidal 1977a, 1977b, 1977c, 1977d) ${ }^{5}$, y Víctor Barriga (1939-1940, 19411952) con sus colecciones documentales. Aunque sus estudios no abordan la historia indígena moderna, aportan importantes datos para la comprensión de sus procesos históricos.

Durante todo este período la producción del conocimiento antropológico se articula sobre la idea de grupos sobrevivientes del pasado, reducidos espacialmente a los márgenes geográficos de la región, disminuidos numéricamente, prontos a ser asimilados y, por tanto, desaparecer como grupos distintivos. Es una visión pesimista acerca del futuro del indígena, por lo que los conocimientos que se generan tienen el sabor del rescate cultural. Para explicar la presencia y estado de estos pueblos se aplican nociones de origen difusionista (con hipótesis históricas de génesis, distribución, intercambio y préstamos culturales) o evolucionista (se trata de grupos que han quedado fuera de su curso central por la propia historia y la civilización). Estas interpretaciones consideran enormes lapsos de tiempo y cubren extensas regiones geográficas.

La adjetivación de pueblos relictuales, de origen botánico, parece ser la más adecuada para 
caracterizar la forma de apreciar, diagnosticar y valorar las poblaciones indígenas regionales que entregan los etnólogos y arqueólogos, desde mediados del S. XIX hasta mediados del siglo XX. Con importantes variaciones según los grupos $\mathrm{y}$ los sectores, éstos se ubicaban al interior de lo que hemos llamado el "paradigma semántico del indio" (grupos que por sus formas de vida y condición social se encuentran en el extremo más tradicional y atrasado de la sociedad $)^{6}$. Es bueno señalar que los grupos interpelados tenían de sí mismos una visión bastante diferente de la propuesta por los etnógrafos y otros estudiosos que escribieron sobre ellos durante este período. De esta manera, el objeto antropológico y el sujeto soporte de esas representaciones guardaban entre sí una distancia abismal. No obstante, como se puede apreciar desde la actualidad, es una antropología que produce distinciones y definiciones que varias décadas más tarde serán la materia prima de fenómenos de clasificación y tipificación étnicas, no sólo al interior de la propia disciplina, sino también entre los propios sujetos indígenas.

\section{El Inicio de la Profesionalización de la Antropología (1950-1973)}

En el marco de un proceso que se desarrolla por toda Latinoamérica desde la postguerra y bajo una influencia dominante de la antropología europea y estadounidense, encontramos por primera vez en la zona etnólogos profesionales en que los estudios etnográficos detallados caracterizan su desempeño. Se trata de investigadores nacionales y extranjeros, algunos de los cuales formaban parte de misiones científicas. Con ellos también se inicia la institucionalización de la antropología en el país, primero con la formación de un centro de investigaciones antropológicas en la Universidad de Chile y luego con la creación de carreras de pregrado en la disciplina. Junto a la antropología realizada por profesionales, el conocimiento de las poblaciones indígenas del norte también recibe el aporte de historiadores vinculados a universidades regionales y sedes locales de universidades nacionales. Hacia finales de este período y coincidiendo con los procesos sociales y políticos que se vivían en el país, las prácticas antropológicas se vinculan también a las problemáticas del cambio social desarrollista y revolucionario.

\section{Los indígenas como sujetos etnográficos}

En este período encontramos por primera vez descripciones etnográficas más elaboradas, no obstante su notoria carencia de teoría explícita. Son etnografías parciales o locales, sin alcances regionales y con énfasis en la cultura material y las "costumbres". Se detecta una fuerte influencia de la etnografía del norte y centro de Europa. A diferencia de la etnología mapuche, se carece para la zona de estudios sustentados en las antropologías más desarrolladas de ese entonces, la inglesa, francesa o norteamericana. Asimismo, son etnografías sin contexto histórico, desvinculadas de estructuras de poder o de sistemas más amplios que envuelven a los sujetos de las descripciones. Se pueden definir como etnografías "museográficas", centradas en "inventariar" la cultura y, por lo tanto, con una visión básicamente estática de la misma. Para ellos, los indígenas radican en los márgenes de la sociedad nacional, como una suerte de "relictos" aislados, cuyo destino más probable será desaparecer ante los embates del progreso. Grete Mostny inaugura en 1949 este estilo de estudios monográficos con su trabajo en la localidad atacameña de Peine (Mostny 1954) 7 . Thomas Barthel, etnólogo alemán, invitado por la Universidad de Chile, realiza su estudio sobre el "culto" del agua en Socaire (Barthel 1959, 1986). En esta misma localidad y en otras del norte destaca también el aporte de Carlos Munizaga, acompañado de Hugo Gunckel (Munizaga y Gunckel 1958) o de manera individual (Munizaga 1963), con sus trabajos referidos a la etnobotánica y medicina andinas. A finales de los años sesenta, como miembro de una misión del Museo Naprostek de Praga ${ }^{8}$, Vaclav Solc realiza investigaciones en Ollagüe, en la precordillera de Arica y en el altiplano de Iquique, de donde proviene su descripción de la construcción

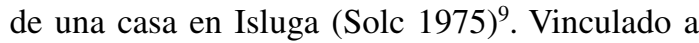
la misión checa, también llega el etnólogo Peter Neumann, miembro del Museo de Dresden de Alemania oriental, que igualmente trabaja en la zona precordillerana ariqueña y publica un informe de su misión en colaboración con Solc (Neumann y Solc 1968). Dentro de este grupo también se podría incluir a Bernardo Valenzuela (1969-70) con su trabajo sobre los pueblos del río Salado; la etnóloga danesa Bente Bittmann, que llega al norte de Chile en 1970, con sus aportes a la etnohistoria de la costa, especialmente su importante trabajo sobre Cobija (Bittmann 1979, 1983, 1984) ${ }^{10}$; y las 
contribuciones etnobotánicas de George Serracino et al. (1974) y sobre las prácticas pastoriles de los dos primeros (Serracino y Stehberg 1975), resultados del desarrollo del proyecto arqueológico Guatín que pertenece a este período.

\section{Los historiadores regionales y los indígenas}

Se trata de historiadores con intereses regionales, algunos de ellos ya con formación universitaria, que se interesan por el estudio de la historia y la sociedad del norte de Chile. Su actividad se ampara en las sedes universitarias regionales que por ese entonces -hacia finales de la década de 1960- se están creando. Los autores más importantes son Oscar Bermúdez con un extenso trabajo historiográfico centrado en la génesis de la industria del salitre y, de mayor interés aquí, sus estudios sobre la localidad de Pica y Tarapacá en general (Bermúdez 1973, 1975, 1980, 1987); Alfredo Wormald con sus contribuciones sobre la historia de Arica y las zonas interiores de la provincia (Wormald 1966, 1968, 1972); José María Casassas con su aporte a la historia, especialmente eclesiástica, de la región de Atacama (Casassas 1967, 1974a-f). Cabe mencionar todavía trayectorias como las de Jorge Checura $(1965,1967,1968,1976)$ en Iquique y de Luis Álvarez ${ }^{11}$ en Arica. En la mayoría de los casos no se trata de una mirada historiográfica centrada en el indio, sino que más bien en las regiones o áreas de ellas donde es importante la presencia indígena atacameña o aymara. Por lo tanto no se trata de una historia indígena, sino de las ciudades o de los asuntos regionales desde la perspectiva de los grupos dominantes o los centros de poder, donde lo indígena resulta más o menos periférico. Estos historiadores mantuvieron una estrecha conexión con las capas dirigentes e intelectuales de sus ciudades, además de alcanzar un reconocimiento amplio por su activa participación en la prensa local. Esta posición permitió la publicación de síntesis de historia regional y local de divulgación amplia.

\section{Intelectuales, indígenas y desarrollo}

Durante la década de los años sesenta, pero sobre todo a inicios de los setenta, la investigación social (antropológica, histórica, sociológica y de geografía humana) acompaña la intervención desarrollista. Es el período donde se imponen fórmulas asociativas cooperativas, se modifica la infraestructura de regadío y acumulación, se intervienen los antiguos calendarios y los sistemas de organización y distribución de las aguas; se inducen cambios tecnológicos, como la innovación de cultivos, la introducción de maquinaria, etc. El símbolo de esta orientación lo constituirá la estación de campo experimental: en Caquena, Colchane y San Pedro de Atacama. En este contexto, especialistas de las ciencias sociales son convocados a diagnosticar o informar los alcances, las consecuencias e impacto de estas intervenciones o de proyectos con mayor alcance como los de la reforma agraria; más tarde, un grupo de cientistas sociales se planteará objetivos más radicales como el del tránsito de la comunidad andina al socialismo.

Desde el punto de vista de la calidad de la investigación, los trabajos mejor logrados vienen de geógrafos que estudian San Pedro de Atacama por encargo de la Corporación de Fomento, en función de generar cambios en la agricultura y la sociedad locales (Aranda 1964; Aranda et al. 1968). Existe también un trabajo geográfico sobre Chiu-Chiu (Baulieu 1967) y varios informes agronómicos y socioeconómicos para los sectores intervenidos por la Corporación de la Reforma Agraria (CORA) en Lluta, Azapa, Camarones y Pintados, en los cuales existe una notoria presencia andina, y otros informes elaborados por profesionales del INCONOR, dependiente CORFO, como el de Sady Guzmán (1969) sobre las comunidades de Isluga. En general, se trata de diagnósticos dirigidos a orientar la acción para el desarrollo rural, una línea de estudios de un carácter eminentemente técnico, donde lo indígena aparece sólo como una referencia marginal.

El proyecto de tránsito democrático hacia el socialismo hace de la planificación del cambio una cuestión importante que, para el caso andino, moviliza a diversos profesionales, incluidos algunos arqueólogos, como Lautaro Núñez y Patricio Núñez, además de los geógrafos Freddy Taberna que realiza un trabajo pionero sobre Isluga y el interior de Iquique (Taberna 1968a, 1968b, 1971 y 1996[1968]) $)^{12}$ y Luis Alvarado sobre las comunidades de la precordillera de Putre (Alvarado 1970). Es una investigación que a partir de 1970 se pondrá al servicio del tránsito hacia el socialismo en la sociedad andina (Taberna 1973). También, en el marco de las actividades del plan gubernamental de reforma agraria, Raúl Atria (1970) elaboró un informe sociológico sobre valores en la zona precordillerana de Arica. Es interesante destacar 
que la envergadura de los cambios propuestos se sustenta en muy poca información, al menos publicada, siendo el estudio más detallado el de Alvarado. Por lo tanto, se basan en un conocimiento que proviene principalmente de lecturas y de sus experiencias personales, las que son elaboradas conceptualmente con la terminología marxista de la época. Concluyen que existen elementos en la sociedad andina que pueden ser aprovechados en el tránsito hacia el socialismo; pero también otros que lo hacen retardatario. Estos últimos pueden ser tanto de carácter externo (atracción migratoria, imposición de nuevos patrones culturales, acción de la burguesía regional, etc.) e internos a la tradición andina (pasividad, pragmatismo, oficialismo, etc.). Esta mirada, organizada según premisas marxistas, incluía dos componentes. Por una parte, la sociedad indígena era uno de los grupos regionales que más requería de cambios dada su marginación histórica. Por otra, se asume en ella la existencia de un potencial revolucionario basado en la permanencia de instituciones sociales colectivistas ${ }^{13}$.

Los principales exponentes de esta línea son Ximena Aranda que estuvo a cargo de la macro zona norte de la Oficina Regional de Planificación (ORPLAN) entre 1970 y 1973, que mantuvo un activo contacto con Freddy Taberna, jefe de ODEPLAN en Iquique, a los que se añaden Lautaro Núñez, Patricio Núñez y, al final, Gabriel Martínez. ¿Cómo entender la emergencia de un grupo que postuló el tránsito andino hacia el socialismo? En el tapete de la discusión se puede poner la influencia de la revolución cubana y el papel que puede jugar el campesinado, sector social que es revaluado en Latinoamérica respecto de su potencial de incidencia en cambios estructurales. Algunos de estos jóvenes profesionales, a su vez, tenían una formación marxista previa y se nutren ideológicamente del contacto con intelectuales nacionales como el arqueólogo Julio Montané o la figura de Alejandro Lipschutz, además de nexos con otros intelectuales de izquierda en Perú, Bolivia y Argentina. Sus conocimientos sobre el mundo andino regional provenían de sus viajes por las zonas interiores, de su participación en algún proyecto específico (como el Plan Andino impulsado por la Municipalidad de Iquique a fines de los años 1960), y del conocimiento de iniciativas desarrollados en la zona por la Corporación de Fomento (CORFO), la Corporación de la Reforma Agraria (CORA) o la Junta de Adelanto de Arica. El grupo se disuelve con el golpe militar.
A diferencia del período anterior donde el indígena está desapareciendo (lo que justifica y funda una etnografía interesada en constatar las supervivencias), ahora éste aparece como un problema para el desarrollo o el cambio social, precisamente por sus atributos atávicos. El tipo de información que se persigue busca retratar al indígena principalmente desde una perspectiva socio-económica, ya no el indio sobreviviente sino el pequeño productor agropecuario de origen indígena, sujeto posible de políticas de cambio y desarrollo. Si los pueblos andinos antes estaban en el margen geográfico y social, ahora ese estado puede y debe ser modificado al integrarlos a un proyecto político de cambio. Pese al exceso ideológico y su voluntarismo, se debe destacar el sentido de inclusión social que implicaba esta propuesta.

\section{La Antropología Andina Bajo la Dictadura (1973-1990)}

Aunque existen antecedentes de actividad antropológica válida en el área andina antes del período autoritario, una antropología profesional desarrollada por cientistas sociales formados o titulados en la disciplina en centros universitarios nacionales, se realiza básicamente durante los años de dictadura. En un primer momento, la generación de conocimientos sobre los indígenas del norte de Chile se retrotrae casi exclusivamente al alero de las universidades. Luego reaparece nuevamente la preocupación por el desarrollo, pero esta vez regida por la visión geopolítica y el modelo neoliberal del gobierno militar. "Jibarizados" los organismos públicos de apoyo, la implementación de estudios y programas estatales se realizará a través de algunas entidades ligadas a universidades regionales o consultoras privadas.

La actividad universitaria y estatal continuará durante todo el período, pero a comienzos de la década de 1980 aparecerá un nuevo enfoque hacia lo indígena y también una nueva manera de abordar su desarrollo con la formación de los organismos no gubernamentales (ONGs). Éstos plantean su actividad desde una crítica a las políticas estatales y al autoritarismo, incluyéndolas dentro de procesos históricos de subordinación de más larga duración. A estos efectos, desarrollaron estudios sobre las transformaciones sufridas por las sociedades andinas, pero ya no sólo desde una perspectiva económica, sino también desde otros aspectos como la educación, 
la organización social, la “chilenización”, el cambio religioso, la salud y otros, lo que originó una abundante actividad editorial.

\subsection{El período previo a la aparición de los organismos no gubernamentales (ONGs)}

\section{El conocimiento de lo indígena y su retracción a la investigación universitaria}

En los primeros años de dictadura la práctica profesional antropológica y de disciplinas afines en el norte del país se disocia, evidentemente, de cualquier toma de posición pública ligada al marxismo o al cambio social orientado por esta doctrina. Investigadores con posturas radicales o progresistas fueron asesinados (como Freddy Taberna), debieron partir al exilio (Luis Alvarado) o, sencillamente, tratar de pasar desapercibidos para no sufrir las consecuencias de la represión (Lautaro Núñez, Juan van Kessel, Gabriel Martínez, Verónica Cereceda, Patricia Provoste). La acción de estos autores es principalmente académica (con la excepción de Gabriel Martínez y Verónica Cereceda que investigaban activamente al tiempo que mantenían un proyecto de artesanías en Isluga), bajo el alero de instituciones universitarias regionales o nacionales.

Se crea la revista Norte Grande que, entre 1974 y 1979, además de órgano de difusión del Taller del mismo nombre del Instituto de Geografía de la Universidad Católica de Chile de Santiago, publicó a algunos autores emergentes en ese momento, como Horacio Larraín (1974a, 1974b, 1974c, 1975, 1978-1979; también Larraín y Couyoumdjian 1975), Juan van Kessel (1974a, 1974b, 1975a, 1978-1979), Gabriel Martínez (1975b), Pedro Guerra (1975), Alden Gaete (1975) o Fernando Dougnac (1975) ${ }^{14}$. Algunos autores, como Larraín (1987), participan de proyectos de investigación y editoriales concordantes con iniciativas de las autoridades de la época (por ejemplo, los aspectos etnográficos de la Geografía de Chile del Instituto Geográfico Militar). Por primera vez, también, aparece una descripción fonológica del aymara regional, realizada por Christos Clairis (1976).

La orientación de los estudios y la generación de conocimientos adquirieron un derrotero marcadamente etnográfico. Si poco antes la preocupación era la socioeconomía (los indígenas deberían desarrollarse, cambiar, modernizarse tecnológicamente, etc.) y la política (más o menos progresistas o reaccionarios), ahora el problema es el de las prácticas sociales y culturales en un nivel estrictamente local (la comunidad), y ya no en perspectiva con la sociedad regional y nacional. Aunque la temática del desarrollo sigue estando presente, con diversos matices, priman perspectivas tradicionalizantes. El cambio es, en general, visto como una amenaza externa que si no se puede neutralizar se debe al menos encauzar, controlar, administrar, etc. La visión antropológica encapsula al indígena en la tradición, muchas veces rechazando la validez de las opciones de cambio adoptadas por las comunidades y sus dirigentes.

Hasta la década de los sesenta la actividad antropológica en el norte era poca y más bien de rescate, lo que la acercaba bastante al museo, los arqueólogos y sus problemáticas. Inmediatamente antes del quiebre democrático las disciplinas antropológicas se están diferenciado más: arqueólogos al sitio y antropólogos a la comunidad. La convergencia entre ambos se da en el proyecto político de cambio. Ahora en este período llega una nueva etapa en que ambas disciplinas no se confunden, pero igualmente se reúnen en torno al objeto o la problemática de estudio, lo que se consigue a través del marco de la propuesta integradora de John Murra. Para salvar el hiato entre la etnografía y la arqueología de campo aparecen los etnohistoriadores o las práctica del trabajo etnohistórico. Esto genera variadas "invasiones": arqueólogos interesados por la etnohistoria y más tarde por la etnografía; antropólogos que le otorgan profundidad histórica a su objeto de estudio y se familiarizan en el manejo de documentación de archivos; etnohistoriadores que dialogan con antropólogos y arqueólogos, etc. Se trata de un diálogo enmarcado por la consolidación de lo andino como un problema y objeto complejo de investigación. La planificación del cambio no forma parte relevante de la discusión. Se inventa colectivamente "lo andino", cuya continuidad es posible rastrear desde el período precolombino hasta la actualidad. Se trata de un concepto que permite unir profesiones, profesionales y prácticas de investigación muy diversas. Quizás el momento que simboliza mejor esta tendencia sea la reunión de diversos investigadores en Isluga de 1982, en tanto que la figura ejemplar que representa este diálogo es el actual premio nacional de historia Jorge Hidalgo ${ }^{15}$. 
Bajo este amplio y laxo paraguas de producción de conocimientos acerca de lo andino, convivieron de manera más o menos armónica distintas tradiciones teóricas y metodológicas que van desde el estructuralismo francés, en los importantes trabajos de Gabriel Martínez (1974, 1975a, 1975b, 1976, 1987, 1989) y Verónica Cereceda (1977, 1978, 1986, 1988, 1990), hasta las tesis de la modernización desestructuradora (derivada de la teoría de la dependencia) en Juan van Kessel $(1980 a)^{16}$, pasando por la propuesta del control vertical de un máximo de pisos ecológicos de John Murra $^{17}$. Se manejan dos visiones sobre el futuro de las sociedades andinas. Una optimista postula la posibilidad de continuidad de la tradición aún en contextos de modernización; otra pesimista postula una discontinuidad absoluta, el holocausto de la tradición por la modernidad. La primera es ejemplificada por Gabriel Martínez y, sobre todo, Tristán Platt ${ }^{18}$ y su trabajo sobre la instalación de inmigrantes andinos en la parte alta del valle de Azapa (Platt 1975a), donde plantea la posibilidad de reconstitución de la tradición en contextos de intervención directa, como los de reforma agraria. Para la segunda, la referencia obligada es la tesis sostenida por Juan van Kessel en su trabajo doctoral citado, que postula el "holocausto" de los aymaras de la provincia de Iquique frente al "progreso".

Durante este período también se desarrollan varias tesis de grado sobre comunidades indígenas de la zona. Marcos Rissetti, egresado de antropología de la Universidad de Concepción, trabaja sobre la estructura de la propiedad de la tierra en Belén (Rissetti 1977). Patricia Vargas (1979) realiza su trabajo en Isluga, Carlos Gómez (1980) en Toconce y Priscila Délano (1982) en Caspana, todos egresados de antropología de la Universidad de Chile. También desarrollan sus tesis en el área alumnos de la carrera de sociología de la Universidad del Norte. Patricia Provoste (1980) la realiza sobre el tema de la comunidad andina. Otro grupo de alumnos ${ }^{19}$, guiados por Juan van Kessel, profesor de esa misma unidad académica, trabajan alrededor del problema de la desintegración cultural aymara, cubriendo un amplio abanico temático: Bernardo Guerrero (1978) trabaja la influencia del pentecostalismo; Eduardo Pérez (1978) analiza las consecuencias de los modelos de desarrollo; Yerny González y Lucy Ramírez (1980) escriben sobre los cambios en la estructura familiar; y Juan Podestá (1981a) acerca del impacto de la educación pública ${ }^{20}$.

\section{La planificación del desarrollo rural: antropólogos, indígenas y geopolítica}

La zona andina regional, por su carácter fronterizo, es enfocada geopolíticamente ${ }^{21}$ por el gobierno militar y se aplican una serie de medidas destinadas fundamentalmente a retener población, todas en el marco del modelo neoliberal de desarrollo que adquiere mayor claridad a partir de 1978. La necesidad de información diagnóstica para la planificación es encargada a instituciones universitarias, como el Centro Isluga de Investigaciones Andinas ${ }^{22}$ de la Universidad del Norte, sede Iquique; o, de manera eventual, a consultoras privadas, como CONSECOL (1988), que realiza un diagnóstico de la situación rural en la provincia del Loa. En estos estudios participan antropólogos, como Victoria Castro (1987), junto a sociólogos y otros profesionales vinculados al desarrollo agropecuario. En esta línea aparecen una serie de trabajos de algunos miembros del Centro Isluga, que trabajan principalmente en la comunidad homónima, ubicada en el altiplano de Iquique, comuna de Colchane. Destacan los aportes de Patricia Provoste, que trabaja aspectos económicos, organizacionales y migratorios (Provoste 1977, 1978a, 1978b, 1978c, 1979a, 1979b, 1981), Italo Lanino (1977a, 1977b) que describe las explotaciones agrícolas y ganaderas y el de Ignacio Albornoz (1977) que analiza las condiciones de suelos y aguas. Dentro de este mismo contexto se puede ubicar la tesis de grado de Patricia Schmidt (1980), que realiza como funcionaria de ODEPLAN. Se trata, en general, de informes diagnósticos de carácter estrictamente técnico y de orientación economicista, vinculados a un tipo de planificación del desarrollo que se presenta desnudada de un ropaje político, enmarcada en una supuesta asepsia ideológica, que pretendía invisibilizar la carga neoliberal y geopolítica que impregnaba las acciones del gobierno militar. El indígena es percibido como un sujeto pasivo, atrasado y pobre, que debe recibir el apoyo estatal para sobrevivir, modernizarse y progresar económicamente. Para lograr este objetivo el Estado debe acercar el progreso y el cambio al sector rural, de manera que esta población no abandone las zonas interiores. Llegan así, de una manera planificada, los subsidios monetarios, la educación con una acrecentada carga nacionalista, las estaciones médicas rurales, la donación de insumos agrícolas, los grupos electrógenos, el agua potable, las techumbres de zinc, el concreto y, por último, los alcaldes designados. 


\subsection{El período de los organismos no gubernamentales (ONGs)}

\section{Indígenas y organismos no gubernamentales (ONGs)}

A comienzos de la década de 1980 surgen las ONGs en el norte del país, creadas por profesionales provenientes de las ciencias sociales, entre ellos varios antropólogos y sociólogos interesados en el tema andino, que contaron con los auspicios de la cooperación internacional. La investigación también adquiere un carácter diagnóstico, pero dentro de propuestas que critican las políticas del gobierno militar y plantean alternativas para el desarrollo andino que se pueden sintetizar en el concepto de etnodesarrollo, esto es, con adecuación a los antecedentes sociales, históricos y culturales de las poblaciones andinas ${ }^{23}$. Vista en el largo plazo, todavía parece una posición éticamente correcta, aunque bastante insustancial en muchas de sus consecuencias. Las ONGs se involucraron también en un proyecto más amplio de rearticulación del tejido social y realizaron diversas experiencias piloto de apoyo al desarrollo de algunas comunidades. De esta manera, si antes los antropólogos comprometidos informaban o denunciaban, ahora también podían ser activistas o agentes de intervención directa, donde resalta la figura del antropólogo "capacitador" en la comunidad de indígenas.

Los grupos indígenas andinos interesaron vivamente a las ONGs y, de hecho, muchos de sus integrantes eran antropólogos o sociólogos que habían trabajado en el sector rural con el mundo aymara. Sin embargo, la mayoría de estas instituciones no trabajó exclusivamente con la población indígena regional, sino también con los sectores pobres y marginados de la sociedad regional. La temática indígena se incorpora así dentro de una visión global acerca del mundo popular, siguiendo líneas transversales que involucran también la pobreza, las mujeres, la educación, las tecnologías apropiadas, la economía solidaria, etc. A pesar de que al aymara se le sitúa en el ámbito de lo rural, en sus antiguas comunidades, en el contacto con los espacios sociales populares, actuales (las poblaciones marginales urbanas) o del pasado reciente (la pampa salitrera), se les aparece, insospechadamente, el "indio". Por primera vez los antropólogos se dan cuenta cabal que el problema indígena del norte del país no es sólo una cuestión rural, sino también industrial y urbana. Las consecuencias prácticas y de investigación de esta constatación fueron variadas, en ningún caso uniformes. En el Centro de Estudios de la Realidad del Norte (CREAR, ex-CIREN), dada la influencia de van Kessel sobre sus ex alumnos, este fenómeno se aborda desde la tesis de la desestructuración. En el Taller de Estudios Regionales (TER) se postula la existencia de un grupo subordinado, pero con capacidad de constituirse en actor social y político. En el Taller de Estudios Andinos (TEA), siguiendo la vena anterior, se adopta una postura que permita recuperar la complejidad de los procesos y la dinámica social andina: por ejemplo, entender cómo era posible que en las ciudades y entre los aymaras jóvenes, donde se planteaba la mayor desintegración, precisamente allí surgiera un novedoso movimiento con carácter étnico y con una ideología neotradicionalista.

A pesar de la escasez de recursos, estas ONGs desarrollaron una importante línea editorial, destacando en ello el CREAR, seguido por el TER y el TEA. Aparte de cartillas de rescate y difusión de tecnologías tradicionales o manuales de educación alternativa, que supusieron también la generación de conocimiento etnográfico, estos organismos editaron varios textos, de mayor o menor extensión y alcance; además de publicaciones que parte de sus investigadores divulgaron en otros medios. Sus trabajos tratan sobre la situación general de los aymaras (B. Guerrero et al. 1984; Gundermann 1985d, 1987), notas sobre su historia (Olmos 1987), su participación en el ciclo salitrero (S. González 1987, 1989), recopilaciones de mitos y leyendas (Podestá et al. 1989), el impacto de las políticas de desarrollo (S. González 1981; Pérez 1984) y la situación de los derechos indígenas (Olmos 1988a; Olmos y Pérez 1988a), o sobre temas más específicos como la influencia de la educación (Podestá 1980, 1981b, 1987; S. González 1988), el avance del pentecostalismo (Guerrero 1980, 1981, 1984, 1987; van Kessel y Guerrero 1987), la desestructuración de la familia (Y. González 1980), la economía campesina (Pérez 1988c; H. González y Gundermann 1989), el manejo ganadero (Gundermann 1984b, 1988b; Pérez 1988a), ganadería, mercado y diferenciación interna (Gundermann 1986), actividades productivas (Olmos y Pérez 1988b), la propiedad de la tierra en parques nacionales (Salinas 1986, 1987), los recursos hídricos (Olmos 1988b) y los sistemas de regadío, estrategias de subsistencia y manejo de recursos (Y. González 1985), la tecnología 
(Pérez 1981), la manufactura artesanal (Gavilán 1985a; H. González 1988; Gundermann 1988a; Gundermann y H. González 1989), la posición de la mujer (Gavilán 1985b, 1988; Pizarro 1988), los sistemas de organización social y política (Pérez 1988b; Salinas 1989), la identidad cultural (H. González y Gavilán 1989), la migración a la ciudad (J. González 1987, 1988), además de la publicación de encuentros y seminarios específicos $(\mathrm{H}$. González y Guerrero 1990) y sistematizaciones de experiencias de promoción (por ejemplo, Guerrero 1986). En el área atacameña, también se realizan algunos trabajos destinados a informar iniciativas de desarrollo del artesanado local financiadas por el Obispado de Calama (Larraín 1989; Larraín y Ross 1988$)^{24}$.

El recuento bibliográfico señala que fue un período de gran producción intelectual sobre los indígenas regionales y se generó mucho conocimiento, especialmente sobre los aymaras (Arriaza 1991). En estos trabajos la historia es poco tratada y, salvo excepciones, la caracterización y la denuncia no van acompañadas de elaboraciones conceptuales y buenos empalmes con la teoría social, al menos de manera explícita y con cierto nivel de despliegue o desarrollo. Asimismo, pese a la constatación de su importancia y amplitud, tampoco se aborda el fenómeno urbano aymara ${ }^{25}$ y continúa la obsesión por la comunidad rural. Los factores que parecen concurrir en esta situación son la falta de preparación académica en las escuelas de antropología de ese entonces para abordar esos temas; la propia complejidad del fenómeno; un fuerte fijación exotista del objeto de estudio derivado de la antropología clásica o, si se quiere, un hábito de sensibilidad intelectual por la diferencia (que, ciertamente, no se visualizaba en lo urbano); y, por último, el hecho de que el sujeto social indígena milenario, resistente, atacado por las fuerzas del Estado y el capital, era mucho más atractivo para la cooperación internacional. Se plantea así una convergencia de estereotipos: el de los antropólogos y el de las agencias que financiaban a las instituciones de las cuales eran miembros.

\section{Los indígenas y la antropología universitaria}

En la década de los años de 1980 la antropología social desaparece definitivamente de las universidades regionales, producto del control político y la censura ejercida por los rectores delegados del gobierno autoritario ${ }^{26}$. De esta manera, los únicos antropólogos dependientes de entidades universitarias que trabajaron durante este período en la zona fueron los de la Universidad de Chile de Santiago. Junto a ellos también llegan varios tesistas e investigadores de universidades del extranjero.

María E. Grebe, siguiendo los lineamientos teóricos de la antropología cognitiva, trabajó aspectos de la música (Grebe 1980), la cosmovisión andina en Isluga (Grebe 1981, 1983), el simbolismo (Grebe e Hidalgo 1988), el pastoreo (Grebe 1984a), la etnozoología (Grebe 1984b) y, además, la migración altoandina a los valles agrícolas occidentales y a las ciudades de Pozo Almonte e Iquique (Grebe 1986a). La factura de sus estudios sobre la cosmovisión, tanto en sus procedimientos metodológicos como en sus inferencias, ha merecido dudas y reparos, ya que sus conclusiones son sospechosamente cercanas a las que había llegado respecto del mismo tema en el caso mapuche. Su trabajo sobre las migraciones se puede considerar como su aporte de mayor interés, básicamente por ser el primer trabajo publicado sobre el tema; y porque, asimismo, es capaz de percibir que la dinámica de la etnicidad y la identidad étnica pueden seguir lógicas diferenciadas, lo que podría expresarse según la ecuación siguiente: a menor etnicidad en medios urbanos, mayor conciencia de identidad étnica. Milka Castro, junto a las biólogas Carolina Villagrán y Mary Kalin, realiza un estudio etnobotánico (Castro et al. 1981) y trabaja sobre las estrategias de subsistencia en la precordillera de Arica (Castro 1982). Más tarde, junto con otros colaboradores, efectúa estudios sobre tenencia de la tierra y uso del agua de riego en la misma zona, cuyos resultados serán publicados en este período o un par de años más tarde (Castro y Bahamondes 1987, 1988; Castro et al. 1991; 1992). Sus estudios tienen un carácter más marcadamente etnográfico descriptivo, sin mayor incorporación teórica, hipótesis históricas o marcos de interpretación social más amplios. Al final de este período M. Dannemann y A. Valencia (1989) publican un trabajo de síntesis sobre la situación y distribución de los grupos aborígenes chilenos, que sitúa erróneamente un enclave quechua en la comuna de G. Lagos.

Durante este período se inician también extensivas investigaciones etnográficas en el Alto Loa, por parte de un grupo de arqueólogos y antropólogos de la Universidad de Chile y del Museo Chileno de Arte Precolombino, dirigidos por Victoria Castro y Carlos Aldunate. Su interés etnográfico se originó 
en la adopción de una perspectiva etnoarqueológica, presente ya en su tesis de licenciatura sobre las chullpa de Toconce (Aldunate y Castro 1981) ${ }^{27}$. A pesar de que esta experiencia dará sus mejores frutos durante la década siguiente, a este período corresponden la realización de un trabajo sobre sacralidad (Castro et al. 1980), un estudio etnobotánico con la colaboración de biólogos (Aldunate et al. 1981), otro sobre etnozoología (Castro 1986) y la publicación de la entrevista a un yatiri (Castro 1988), todos en la misma comunidad de Toconce; además de un trabajo denuncia sobre la desecación de las vegas de Turi (Aldunate 1985) ${ }^{28}$. También en la misma línea algunos trabajos arqueológicos, especialmente sobre arte rupestre, utilizan información etnohistórica y etnográfica (Berenguer y Martínez 1986, 1989).

El área recibe también la visita de tesistas de postgrado provenientes de universidades extranjeras (incluidos algunos chilenos). El geógrafo norteamericano Wayne Bernhardson, en el marco de su tesis de maestría, trabajó sobre pastoralismo y recursos hídricos en la zona de Parinacota (Bernhardson 1982, 1985a, 1985b). El hispano-canadiense Juan Carlos Folla (1989) realizó una tesis acerca de la economía campesina de la comunidad atacameña de Socaire. Patricio Tudela $(1992,1993)$ investigó por esos años los fenómenos religiosos y la transformación de la comunidad andina en los altos de Arica. Penny Dransart $(1988,1991)$ estudió la textilería prehispánica y etnográfica en Isluga. Bernardo Muñoz (1993a, 1993b) escribió una controvertida tesis doctoral sobre los fenómenos de desarrollo y etnicidad en San Pedro de Atacama. María Arratia, proveniente de Canadá, realiza una evaluación de las propuestas y la acción de las ONGs del norte de Chile (Arratia 1991). Además, algunos estudiantes holandeses realizan trabajos en la región bajo la supervisión de Juan van Kessel, en ese entonces profesor de la Universidad Libre de Ámsterdam. Entre ellos se cuentan Jaap Lemereis, cuyo trabajo sobre el tema del desarrollo indígena y el conflicto de aguas en la quebrada de Tarapacá fue re-editado en Chile por CREAR (Lemereis 1987); y Laurens van der Zee, que realiza su tesis sobre educación e identidad entre los aymaras (van der Zee 1989). El mismo van Kessel continúa publicando trabajos que resumen o forman parte de su tesis doctoral en el marco de la propuesta de la desestructuración y otros que anuncian la ideologizada posición que asumirá posteriormente sobre la cosmovisión, la religiosidad, la identidad, la medicina, el trabajo y la tecnología aymara como fuentes de especificidad y emancipación andina frente al saber y el mundo occidental (van Kessel 1980b, 1983, 1985a, 1985b, 1985c, 1985d, 1987a, 1988a, 1988b, 1989a, 1989b, 1989c). De manera paralela, a partir de su estudio original de 1970, publica también trabajos sobre los bailes religiosos y la peregrinación a los santuarios del norte de Chile, acercando su explicación al fenómeno religioso andino (van Kessel 1981, 1984, 1987b).

Durante este período se desarrollan varios estudios lingüísticos sobre el aymara regional. Los trabajos más importantes son los de Brian Harmelink (1985) que compara la fonética y la fonología de esta lengua en las áreas del altiplano de Iquique y Arica, en relación con las variaciones dialectales entre las zonas norte/sur de la altiplanicie boliviana; y el de Enrique Díaz (1990) sobre la estructura fonológica del aymara de la provincia de Iquique. En otra línea, en un proyecto dirigido por Jorge Hidalgo acerca de la educación en la zona andina en la Universidad de Tarapacá ${ }^{29}$, se desarrolló una extensa investigación sociolingüística encabezada por Hans Gundermann, cuyos resultados serán publicados más tarde por este investigador (Gundermann 1990, 1994, 1995-1996), aunque circularon previamente como borrador. Paralelamente, en la provincia de Iquique, una investigación con características parecidas es desarrollada por Sergio González en el Taller de Estudios Regionales, quien también a propósito de la influencia de la educación nacional observó la situación de la lengua materna (S. González 1990a). Para esta misma área, también existe un trabajo de María E. Grebe sobre la relación entre cambio cultural y bilingüismo (Grebe 1986b).

\section{Los indígenas y la investigación histórica}

Se pueden reconocer con claridad dos líneas. Una es la que continúa con el tipo de investigación de los años de 1960, donde los indígenas aparecen en el contexto más amplio de la constitución de una historia regional (Galdames et al. 1981). Aunque recogen hasta cierto punto la influencia de la etnohistoria y la antropología andinas, por diferentes razones sus trabajos no se apoyan en nuevas u originales fuentes documentales. Este es el caso de algunos investigadores del Departamento de Historia de la Universidad de Tarapacá, unidad 
que edita la revista Diálogo Andino ${ }^{30}$. La otra línea representa la profesionalización de la etnohistoria, que desarrolla los aportes más novedosos basados en la pesquisa en archivos nacionales y extranjeros, donde los investigadores más connotados son Jorge Hidalgo y José Luis Martínez. La orientación general de sus estudios, bajo la influencia de John Murra, se podría definir como "internalista", en la medida que el énfasis en la lectura de los fenómenos históricos andinos coloniales se coloca en las lógicas de los actores andinos y en los procesos internos. Aunque no desconocen ni dejan de considerar las fuerzas y factores externos que intervienen sobre la realidad andina, ellos ocupan un segundo plano. Uno de sus principales méritos es que, lejos de plantearse como una historiografía excluyente, en sus prácticas de investigación estos etnohistoriadores han mantenido un fecundo diálogo e influencia recíproca con la arqueología de los períodos tardíos y la antropología socio-cultural.

Sus focos de atención han estado centrados principalmente en la coexistencia multiétnica antes y al inicio de la conquista española, los cacicazgos y las estructuras políticas andinas coloniales, las rebeliones indígenas, los recursos y la movilidad en Atacama y las identidades étnicas. A diferencia de la primera orientación histórica, que se mantiene en gran medida apegada a las crónicas y fuentes secundarias, Jorge Hidalgo y José Luis Martínez realizan un considerable aporte de rescate, transcripción, análisis y publicación de documentación inédita que encuentran en diversos archivos (Hidalgo 1978a, 1978b, 1981a, 1981b, 1982a, 1982b, 1983a, 1983b, 1984a, 1984b, 1985a, 1985b, 1985c, 1986, 1987a, 1987b; Martínez 1985a, 1985b, 1985c, 1986, $1988)^{31}$. Alrededor suyo se empiezan a formar discípulos en las escuelas de historia de la Universidad de Tarapacá, la Universidad Católica de Chile, la Universidad de Valparaíso y la Universidad de Chile, como P. Arévalo, V. Díaz, A.M. Farías, L. Guzmán, M. Lecaros o M. Marsilli, los que aparecen en algunos trabajos (Hidalgo y Díaz 1985; Hidalgo y Arévalo 1987; Hidalgo et al. 1988; 19881989; Lecaros 1986), pero su mayor producción florecerá durante la década siguiente. Aparte de ellos, la etnohistoria atacameña también recibe en este período los aportes Eduardo Téllez (1984) y de este mismo con Osvaldo Silva (Téllez y Silva 1989), sobre la resistencia y la conquista indígena en el S. XVI ${ }^{32}$.

\section{Democratización del País: Reconstitución y Apertura de la Antropología (1990-2000)}

Durante este período, con diferentes resultados, se produce una institucionalización del aporte de la antropología socio-cultural dentro del aparato público y de las universidades regionales. Varios antropólogos, junto con otros profesionales de las ciencias sociales, son contratados por organismos estatales, desde donde realizan su aporte a la planificación del desarrollo de las sociedades indígenas regionales. Otros se incorporan a centros universitarios, donde se embarcan en la creación de nuevas carreras, y continúan sus investigaciones bajo este nuevo alero, pero ya sin la premura del diagnóstico o la urgencia de la denuncia. La actividad de las ONGs, después de un período inicial de crecimiento por su nueva relación con el Estado, empieza luego a decaer, y se transforman en organismos técnicos que ejecutan proyectos y programas licitados por los organismos públicos, pierden gran parte de su capacidad crítica y de producción de conocimiento sobre la realidad indígena.

\section{El indígena como "beneficiario". Las ONGs como ejecutoras de programas estatales}

Durante los primeros años de retorno a la democracia la actividad de las ONGs regionales se vio notoriamente amplificada, ya que su apoyo y servicios fueron solicitados por diversos organismos estatales, como el Ministerio de Bienes Nacionales, la ex Comisión Especial de Pueblos Indígenas (CEPI), la Corporación Nacional Forestal (CONAF), el Instituto de Desarrollo Agropecuario (INDAP), el Fondo de Solidaridad e Inversión Social (FOSIS) y otros. Paulatinamente, abandonan su rol de organismos intermedios interesados en la reconstitución del tejido social y reconvierten su gestión al modo de empresas que prestan servicios especializados al Estado. De esta manera, acentúan más sus capacidades técnicas y menos las políticas, pierden mucho de su sentido crítico y sus marcos de acción empiezan a ser definidos por sus mandantes, las instituciones públicas. Esta tendencia se agudiza con la progresiva disminución del financiamiento internacional. Paralelamente, enfrentan el surgimiento de varias consultoras formadas por profesionales indígenas, a través de las cuales la Corporación Nacional de Desarrollo Indígena (CONADI $)^{33} \mathrm{ca}-$ naliza sus acciones. De esta forma, algunas ONGs 
se vieron obligadas a cerrar, como el Taller de Estudios Regionales (TER); reducir sus actividades, como el Centro de Investigación de la Realidad del Norte (CREAR); o sufrir fracturas internas por conflictos entre sus miembros, en el caso del Taller de Estudios Andinos (TEA), donde la vertiente más tecnocrática y partidariamente incondicional al gobierno se reagrupa en la Corporación Norte Grande. Ubicadas en este nuevo contexto, para las ONGs los indígenas dejaron de ser un actor social al que hay que comprender y acompañar en sus demandas, y se transformaron en "beneficiarios" de proyectos y programas definidos por terceros. Los aportes de estas instituciones a la generación de conocimiento antropológico disminuirán paulatinamente, lo mismo que la notable línea editorial que mantuvieron durante la década anterior.

De todas maneras, en los primeros años de la década de los noventa, antes del éxodo de sus principales investigadores, sus miembros realizan publicaciones sobre la economía campesina (González y Contreras 1994; González y Gundermann 1991 y 1995) y su desarrollo (González et al. 1990, 1993); la ganadería altiplánica y la exportación de camélidos (Gundermann et al. 1990); la complementariedad económica campo-ciudad (H. González 1990); la propiedad de la tierra (H. González 1994); la percepción naturaleza-cultura (Contreras 1994); experiencias de colonización de nuevos espacios rurales (Gundermann y González 1990) y suburbanos (Arriaza 1995); la textilería (Gavilán y Ulloa 1993; Pizarro 1990); la evaluación de la promoción de la producción artesanal (Carrasco, Gavilán y González 1993) y su impacto en las economías domésticas (Carrasco, Gavilán, González y Gundermann 1993); los tintes naturales (Carrasco 1994b); la comunidad andina (Gundermann y González 1992); el desarrollo organizativo (Pérez 1990a) y la participación política (H. González 1991); organizaciones, identidad e integración subregional (González y Gundermann 1994, 1996); la identidad cultural (González y Gavilán 1993); la influencia de la educación nacional (S. González 1990a, 1990b); del pentecostalismo (Guerrero 1990); categorías de pensamiento (Pérez 1990b); la situación sociolingüística (Gundermann 1990, 1994, 1995-1996); diagnósticos comunales (Gundermann y González 1993); además de la bibliografía sobre los aymaras de Arriaza (1991).

Una excepción dentro de este panorama de decaimiento de la productividad de estos organismos la constituye la investigación sobre el tema de género entre los aymaras, que seguirá haciéndose desde las ONGs, principalmente en el Taller de Estudios Andinos y en Norte Mujer, impulsada por Vivian Gavilán y Ana María Carrasco, las que han abordado las diferencias de género entre hombres y mujeres (Carrasco 2003a; Gavilán 1993, 1995, 1996, 1999); género y ciclo vital (Carrasco 1998b); el embarazo y nacimiento (Carrasco 2003b); la construcción cultural de la sexualidad (Carrasco 2005a, 2005b, 2005c; Carrasco y Cofré 2001; Carrasco y Gavilán 2004, 2006, 2007); la violencia conyugal (Carrasco 2001); religiosidad, ritos y género (Gavilán 1998, 2001); la división sexual del trabajo (Gavilán 2002) y la influencia del sistema educacional sobre la misma (Carrasco y Gavilán 2000); la inserción urbana y el trabajo femenino remunerado (Carrasco 1994a, 1998a, 1999; González y Carrasco 1995); la participación social y política de la mujer aymara (Carrasco 1993a, 1997; Gavilán 1997); y, también, diagnósticos generales sobre la situación de la mujer en los sectores rurales de la I Región (Carrasco 1993b). Esta misma institución ha seguido publicando también sobre otros temas relacionados con los aymaras, como el educacional (Echeverría 1999), el ambiental (H. González 1999) y textos sobre divulgación de la historia y la cultura prehispana y aymara (Carrasco y Cofré 2003), incluida su situación posthispánica (Hidalgo y González 2003) y actual (H. González 2003); además de un recuento de las festividades andinas (Gavilán 2003).

También desde una posición marginal a la academia, ligado al CREAR o a través del IECTA, su propia organización, Juan van Kessel continúa sus publicaciones sobre la sociedad (van Kessel 1991b, 2000a), la cosmovisión (van Kessel 1993b, 1993c, 1993d, 1994,1997b), la religión (van Kessel 1990f, 1992c, 1992d, 1992g, 1999, 2001), la organización espacial (van Kessel 1991d), la economía (van Kessel 1992b, 2003), el trabajo (van Kessel 1992e) y la tecnología simbólica andina (van Kessel 1990d, 1990e, 1991a, 1992f, 1993a, 1997a, 2000b; van Kessel y D. Condori 1992). A partir de su tesis sobre holocausto aymara frente al progreso y la modernización, termina elaborando una propuesta casi teológica de valorización del saber andino tradicional como la única vía de emancipación posible para este pueblo, incluido su particular y pesimista diagnóstico de la vitalidad de la cultura aymara y de los procesos étnicos que se inauguran 
a fines de los años ochenta y se potencian con la redemocratización del país (van Kessel 1990a, 1990b, 1990c, 1991c; y el último capítulo agregado a la reedición de su tesis doctoral, 1992a). Alrededor suyo y de su propuesta se agrupan algunos intelectuales indígenas de Chile, Perú, Bolivia y Ecuador, e investigadores y sacerdotes no indígenas, que han participado en eventos que han dado origen a un libro sobre los rituales mortuorios y otro sobre la tecnología andina ${ }^{34}$. Van Kessel colabora también con los capítulos sobre el pueblo aymara (van Kessel 1996a y 1996b) en la obra sobre la etnografía chilena (Hidalgo et al. 1996).

\section{Los indígenas desde el Estado: la inserción de antropólogos en servicios públicos regionales}

La llegada de la "alegría" 35 originó una diáspora de antropólogos y otros profesionales desde las ONGs hacia los servicios públicos y las universidades regionales. Ahora la antropología tiene una inserción legitimada en el aparato gubernamental, aunque dentro de una demanda más amplia de profesionales con experiencia de trabajo con el mundo popular, que incluye lo indígena. En parte ello se explica por el reconocimiento genérico del aporte de las ciencias sociales a la democratización del país, pero, también, por la contribución específica que la antropología puede realizar sobre temáticas como las de las minorías étnicas en particular y a la amplia cuestión de la cultura en general. Estos tópicos, sobre los cuales las burocracias y tecnocracias de gobierno tienen ahora mayor sensibilidad, facilitan la apertura hacia una disciplina social antes relegada a una curiosidad académica o a los museos. Estos antropólogos, en la medida de lo posible, han participado en la elaboración de políticas públicas y en la preparación de diagnósticos, planes y programas de desarrollo. No obstante, su aporte forma parte de propuestas más amplias o se restringe a la ejecución y evaluación de paquetes de apoyo diseñados a nivel central. Sus quejas son recurrentes respecto del agotamiento de sus capacidades en tareas burocráticas, la escasa posibilidad de generar y elaborar conocimientos innovadores en sus radios de acción y competencia, aparte de su dependencia de los vaivenes políticos de la administración estatal ${ }^{36}$. De todas maneras, ellos se incorporan a los organismos de gobierno con las mismas visiones que desde las ONGs se habían generado respecto del mundo indígena. Así, aymaras y atacameños siguen siendo una problemática casi exclusivamente rural, se presta escasa atención al componente urbano y se mantiene una percepción extremadamente rígida de las relaciones campo-ciudad y tradición-modernidad, lo que limita fuertemente la comprensión del sujeto indígena desde su actual complejidad.

\section{Los indígenas vistos desde la academia: la inserción de antropólogos en medios universitarios regionales}

Después de muchos años, se produce la inserción en el medio universitario regional de antropólogos y sociólogos ocupados en la temática andina. Participan de la creación de carreras, como la de Sociología en la Universidad Arturo Prat de Iquique; también se produce su ingreso a unidades eminentemente dedicadas a la arqueología (casos de San Miguel de Azapa y de San Pedro de Atacama) o la historia y geografía (caso del ex Departamento de Antropología, Historia y Geografía de la Universidad de Tarapacá). Quienes se incorporan a estas unidades y centros se han empeñado en realizar estudios de perfeccionamiento académico en Chile y el extranjero, mayoritariamente en búsqueda de formación complementaria y del grado de Doctor, de acuerdo con las nuevas políticas de contratación universitaria. Esta situación está generando, aparte de la formación de las personas, la producción de nuevos trabajos de investigación.

Con participación de antropólogos se está replanteando la función de docencia en unidades que previamente se han dedicado de manera exclusiva a la investigación. En esta perspectiva se puede mencionar la creación de la carrera de Antropología en la Universidad de Tarapacá el año 2006, y previamente de un programa de Magíster, que luego derivará en un Doctorado, a través de una alianza entre la Universidad de Tarapacá y la Universidad Católica del Norte. Se abre aquí la posibilidad de un espacio compartido de trabajo en docencia e investigación entre arqueólogos, antropólogos y etnohistoriadores. Asimismo, una mayor posibilidad de integración disciplinaria entre las ciencias antropológicas. A través de la docencia, el traspaso de conocimientos generados por los investigadores de estos centros y, por cierto, también la formación de generaciones de reemplazo en la misma región, se retoma de alguna manera el proyecto interrumpido que tuvo lugar en la Universidad Católica del Norte 
con su Escuela de Arqueología. Se hace posible también la formación de grupos y equipos de trabajo, cuestión hasta ahora inédita en la organización de la producción del conocimiento antropológico universitario regional.

Por tratarse de un fenómeno reciente no es posible plantear una evaluación del desarrollo del conocimiento antropológico que ha tenido lugar en estos medios. Se pueden atisbar algunas señales de dulce y de agraz. Lo primero es que el conocimiento que se está generando abandona la contingencia, característica de la producción intelectual al alero de las ONGs. En términos de la modalidad de producto ya no se generan diagnósticos, sino que reportes científicos (monografías, artículos en las revistas de la especialidad). Esto tiene una consecuencia respecto del ámbito de difusión de este conocimiento. Ya no es apropiada por los sujetos de referencia (organismos públicos, intelectualidad andina), sino que por una comunidad académica regional y nacional. Pese a ello, desde el Estado y ciertas instituciones se requiere a veces del expertizaje de estos profesionales en servicios de consultorías especializadas (propiedad de la tierra, conflicto andino, educación, etc.). Se trata de incursiones ocasionales o esporádicas y ya no de un quehacer continuo o sistemático. Es de destacar la legitimación de los conocimientos y pericia investigativa de estos profesionales. El aporte académico de antropólogos ha favorecido también que en los órganos de difusión científica de estas unidades académicas aumente el número de páginas destinadas a la antropología. Es el caso de las revistas Chungara y Diálogo Andino en la UTA, la Revista de Ciencias Sociales de la UNAP y Estudios Atacameños de la UCN.

En cuanto al conocimiento que se está desarrollando en las universidades del norte, se consideran temáticas que se arrastran desde el período anterior, cuando algunos de estos investigadores todavía pertenecían a las ONGs, así como algunas apertu$\mathrm{ras}^{37}$. Entre las primeras se deben considerar reseñas generales sobre la cultura aymara $(\mathrm{H}$. González 2001b, 2003), ritos ceremoniales (Larraín 1991); el pentecostalismo (Guerrero 1990, 1992, 1993, 1994a, 1994b, 1995, 1997a, 1997b, 1998); las economías de comunidades (González y Gundermann 1991) y sus transformaciones (H. González 2001a); los cambios en la ganadería (Gundermann 1998a); la complejización de la economía campesina actual (H. González 2004, 2005); caracterizaciones de sectores de comunidades (H. González 2002a); comunidad e identidades colectivas (Gundermann 1998b); comunidad, sociedad y procesos históricos (Gundermann 2001, 2003c); los usos económicos del espacio (H. González 1997b); de los recursos (Rivera 1994b, 1995); la constitución histórica (Gundermann y González 1997) y los sistemas actuales de propiedad de la tierra (H. González 1998a, 2004); los conflictos internos por la tierra (Gundermann 2005a); la presencia indígena en el enclave salitrero (S. González 1991, 1995, 1996a, 2002b, 2002c, 2006) $)^{38}$; la influencia de la educación nacional (S. González 1993, 1996b, 1997, 2000, 2001, 2001-2002, 2002a); la etnoeducación (Podestá 1991, 1993); la educación intercultural (S. González 1998, 1999); la sociolingüística andina (Gundermann 2005b; las influencias del aymara en el castellano hablado en los sectores rurales (Contardo y Espinosa 1991; Espinosa 1996, 1999; Gundermann et al. 2006); la historia del pueblo atacameño desde la prehistoria (Núñez 1992) y la historia andina de los siglos XIX y XX (H. González 2002b; González e Hidalgo 2001; S. González 2002d; Gundermann 2002b, 2002c). Aparte de la tendencia a dar profundidad histórica a antiguos problemas manifiesta en algunos investigadores, como temas emergentes se presentan las migraciones andinas hacia las ciudades costeras y la inserción social y económica urbana (H. González 1996a, 1996b, 1997a; H. González et al. 1996); los derechos territoriales (Barros 1998, 2000); los procesos de etnicidad y de constitución de identidades étnicas (Barros 2004; H. González 1998b, 2000a y 2000b; Gundermann 1998c, 1999, 2000, 2002a, 2004a; Gundermann et al. 2005a; 2005b; Rivera 1994a, 1997, 1999a, 1999b, 2004) ${ }^{39}$; identidad étnica y ciudadanía (Gundermann 1995, 1997, 2003b); etnicidad, poder local y política (Gundermann 2003a, 2004b, 2006); aymaras y poder político regional (V. Guerrero 1996); la población indígena y los estupefacientes (Gundermann y González 1999).

En la revisión de los antiguos temas y en la propuesta de estas nuevas áreas de estudio, se manifiesta con más fuerza la condición histórica y social compleja del sujeto indígena. De esta manera, hoy resulta difícil eludir que aymaras y atacameños son sujetos complejos y dinámicos: circulan entre el campo y la ciudad, cambian de sistema religioso, las bases agropecuarias ya no son el referente principal de sus economías, la comunidad andina ya no tiene sólo un asiento rural sino una definición translocalizada, la sociedad andina se regionaliza, 
la cultura se pluraliza, la propia sociedad se hace más heterogénea, su chilenización no ha conducido al abandono de otras identidades étnicas supuestamente más tradicionales, sino que, posiblemente, las ha reforzado e incidido en la creación de otras, los "jóvenes de la desintegración cultural" son los adalides de la reformulación étnica y de la adhesión emocional a la tradición, etc. De todas maneras y pese a esta constatación, las reacciones de los investigadores han sido distintas. Algunos han seguido trabajando sobre la tesis simple de la desestructuración y continúan manejando conceptos teñidos por la polaridad tradición-modernidad (como J. van Kessel y B. Guerrero). Otros han optado por buscar nuevas orientaciones teóricas que permitan una mejor comprensión de esta complejidad, desechando inscribir la discusión en esta polaridad y orientando la búsqueda de explicaciones en los propios procesos de modernidad regional (como S. González, H. González y H. Gundermann). Así, en la literatura empiezan a aparecer conceptos y temáticas como las de la relación entre etnicidad y ciudadanía, migración y continuidad cultural, un cuestionamiento de las premisas de la noción de campesinado aplicada a las poblaciones andinas, el conflicto étnico y de nacionalidades y otros. Finalmente, pero ubicadas institucionalmente en ONGs, se ha incorporado el tema de las relaciones de género (principalmente a través de las investigaciones de A. M. Carrasco y V. Gavilán, las que continuarán con sus indagaciones sobre este tema después de su incorporación a las universidades regionales $)^{40}$.

\section{Realidad indígena y consultorías: antropología, planificación regional y acción del Estado}

Aunque sumergida en problemáticas sectoriales, la antropología participa actualmente en la planificación pública regional. Lo hace de manera directa a través del aporte de algunos profesionales que se incorporaron al sistema público; $y$, de manera indirecta, mediante el trabajo eventual de otros que laboran en medios universitarios o en consultoras que realizan estudios por encargo de organismos estatales. Algunos antropólogos participan incluso en la ejecución de programas públicos, incluidos en equipos más amplios de profesionales de los propios servicios gubernamentales, de ONGs o empresas subcontratadas. A través de actividades de este tipo, se ha ido generando conocimiento sobre algunos aspectos de la realidad andina, bajo la forma de catastros y evaluación del uso de los recursos agua y tierra, informes de impacto de proyectos de inversión y otros similares. Con ello se ha logrado crear una base de información básica importante, pero que permanece ampliamente desaprovechada, no relacionada o integrada, ya que muchas veces se desconoce su existencia o es de difícil acceso, por tratarse de informes de trabajo de uso restringido y resguardados por los organismos públicos que los encargan.

\section{Los indígenas desde la metrópolis: la investigación antropológica universitaria desde el centro del país}

En este punto se debe señalar la notable continuidad de los estudios emprendidos en el Alto Loa por arqueólogos que ligan a sus intereses el trabajo etnográfico y etnohistórico, en especial el "Grupo Toconce" constituido originalmente por Victoria Castro, Carlos Aldunate y José Berenguer, a los que se une posteriormente José Luis Martínez ${ }^{41}$. Estos investigadores han seguido explotando la riqueza de la combinación de la investigación arqueológica con la documentación etnohistórica y la información etnográfica (p. ej., Aldunate et al. 2003; Berenguer 2004; Castro y Gallardo 1995-1996; Castro y Varela $2000)^{42}$. Al trabajo de ellos se unen investigaciones de jóvenes antropólogos, tesistas y alumnos vinculados a este grupo y otros profesores de la Universidad de Chile. Es el caso de varios trabajos etnográficos, testimoniales o de rescate, sobre el carnaval de Ayquina (Mercado et al. 1996), la muerte en el Alto Loa (Mercado et al. 1997), la alfarería en Toconce (Varela 1992, 2002), los relatos de un líder ritual en Caspana (Miranda 1997), la organización social, tradición y cambio cultural en Socaire (B. Hidalgo 1992), la tecnología ganadera en Talabre (Morales 1997), la percepción y representación del ambiente entre pastores de Ollagüe (Romo 1998a), el cambio ambiental, pérdida y vitalización cultural en Conchi (Villaseca 2000). Una reunión académica sobre el tema de ciencia andina permitió en enero de 1999 la presentación de diversos trabajos de antropólogos jóvenes, en su mayoría de la Universidad de Chile, de manera independiente o como colaboradores, sobre temáticas como la del pastoralismo atacameño (Romo 1998b), el conocimiento y manejo de recursos naturales en la zona (Núñez 1998), los fenómenos de transformación de las bases locales 
de sustentación (Villaseca 1998), la etnobotánica atacameña (Villagrán, Castro, Sánchez, Romo, Latorre e Hinojosa 1998; Cárdenas 1998 ${ }^{43}$. María E. Grebe continúa publicando sobre simbolismo (Grebe 1990a, 1990b, 1994, 1995-1996) y la religiosidad aymara (Grebe 1993), siempre en el marco de la antropología cognitiva. P. Tudela (1993, 1994, 2002) aborda las transformaciones religiosas y la chilenización. Milka Castro, otra investigadora de la Universidad de Chile, ha realizado estudios de valoración de recursos agropecuarios en el área atacameña y aymara, lo que representa una continuidad de trabajos que había iniciado la década anterior, ahora bajo la modalidad de consultorías ${ }^{44}$, centrando sus publicaciones sobre el tema de los derechos de aguas de las comunidades indígenas (M. Castro 1996, 1997, 2001a, 2001b) y el pastoralismo (M. Castro 2000; Castro y Bahamondes 1997). Por último, Claudia Zapata (2004), magíster en estudios latinoamericanos, ha analizado la forma en que atacameños y aymaras se plantean frente al tema de la historia y el desafío de presentar su propia versión, a propósito de su participación en la Comisión de Verdad Histórica y Nuevo Trato, así como la relación entre memoria e identidad colectiva entre los aymaras (Zapata 2007).

Cabe mencionar, finalmente, los trabajos de otros tesistas de pre y postgrado en antropología, que realizan sus estudios en el área. M. Ortega (1999a) termina su tesis doctoral sobre identidad indígena y nacionalismo en Isluga. De la Universidad de Chile, J. Salinas (1991) trabaja sobre la tenencia de la tierra en la comunidad de Isluga; K. Tabilo (1997, 1999) sobre relatos orales aymaras; M. Núñez (2002) analiza el impacto minero en la comunidad atacameña de Toconao; D. Rusowsky (2002) trabaja sobre atacameños y medios de comunicación; D. Jofré (2003a), interesada en el manejo del patrimonio arqueológico, indaga también sobre la comunidad actual de Belén en la precordillera de Arica; G. Aránguiz (2004) trabaja en la comunidad de Cariquima; E. Contreras (2005), a su vez, aborda las relaciones fronterizas de los indígenas de la Puna de Atacama. Del Magíster de Género de esta misma universidad, M. S. Pérez $(2003,2005)$ realiza su tesis sobre los significados de la salud en Talabre. De la Universidad Austral de Valdivia, P. Arriaza (1990) trabaja sobre las estrategias de supervivencia campesina en la comunidad altiplánica de Villablanca; O. Aguirre (1995) lo hace en la comunidad precordillerana de Chiapa; mientras que F. Egaña (2005) analiza los casos de un yatiri y un qulliri en la ciudad de Arica. De la Universidad Academia de Humanismo Cristiano, M. Núñez (2000) trabaja en la comunidad atacameña de Peine; Pamela Beltrán R. (2002) sobre la acción y discursos de las organizaciones atacameñas; Patricia Beltrán (2000) sobre rituales en Cariquima ${ }^{45}$. También llegan algunos alumnos de antropología a realizar sus prácticas profesionales, cuyos informes han tenido cierta difusión o han sido publicados. Es el caso de J. Luque (1998) que trabaja el tema de la construcción de la masculinidad entre los aymaras. Algunos alumnos de disciplinas afines a la antropología también desarrollan sus actividades de titulación con los grupos indígenas de la zona. Es el caso de estudiantes de sociología de la Universidad Arturo Prat, como C. Echeverría (1998a) con su tesis sobre el matrimonio y las relaciones de género en Isluga y Cariquima ${ }^{46}$; de R. Aguilera (2002) acerca de las representaciones sociales del Estado entre los aymaras; de derecho de la Universidad de Chile, como F. Báez (2002) sobre el problema del agua entre los atacameños ${ }^{47}$.

Por otro lado, el área sigue recibiendo la visita o los aportes de antropólogos de otros países que llegan a realizar sus tesis o continúan sus investigaciones y reflexiones anteriores. J. L. Anta (1997a, 1997b, 1998), proveniente de la Universidad de Jaén, trabaja en la zona de San Pedro de Atacama, principalmente sobre el tema del choque entre tradición y modernidad. P. Dransart (1995, 1996, 1997, 2002a, 2002b) sigue publicando sobre aspectos simbólicos y rituales relacionados con la textilería y la ganadería en Isluga. M. Arratia (1993, 1994, 1995, 1997a 1997b, 1998), asociada por un corto período a la Universidad de Tarapacá, trabaja sobre el tema intercultural en educación y medicina, realizando también una crítica al modelo de matriz cultural implícito en los aportes de van Kessel (Arratia 1992-1993). B. García (1997), para su tesis doctoral en la Universidad Complutense, trabaja sobre el discurso político de las organizaciones aymaras. Clara Zapata (1999, 2001), estudiante de la Escuela Nacional de Antropología e Historia, realiza su tesis de licenciatura en etnología sobre la reformulación de las identidades entre los aymaras. J. C. Mamani (2003), estudiante en ese momento de la Universidad Mayor de San Simón de Cochabamba, realiza su tesis sobre el tema socio-lingüístico en la provincia de Parinacota. 


\section{La intelectualidad indígena: la construcción de una visión de sí mismos}

En los últimos años ha empezado a emerger una intelectualidad indígena regional. Sus representantes provienen de la historia, las leyes e incluso de disciplinas como la ingeniería y la biología. Además, hoy están formándose y egresando los primeros antropólogos y arqueólogos aymaras y atacameños. El tipo de conocimiento que han generado sobre sus propios pueblos contiene paradojas. Se trata de un tipo de discurso alternativo, que es utilizado para validar tesis ideológicas indianistas y levantar demandas con alcances étnicos sobre la base de una discusión de sus derechos. No obstante, al depender la mayoría de las veces del financiamiento del Estado, específicamente de la CONADI, en lo concreto sus trabajos se reducen en su mayor parte a diagnósticos, que pueden incluir o no algunas declaraciones referidas a estos principios indianistas e indigenistas. Sus contenidos aportan escasa información nueva u original, ya que esta es a veces copiada o reciclada y con niveles de elaboración definitivamente deficientes. Aunque critican fuertemente el cientificismo "occidental" del conocimiento generado por las ciencias sociales y la antropología, se sirven de este mismo tipo de conocimiento para validar sus ideas, argumentos, propuestas o demandas. Normalmente se mueven entre la crítica poco informada y el uso descontextualizado de resultados de investigación antropológica. Las temáticas abordadas en sus estudios se refieren principalmente a la infraestructura de riego, la evaluación de recursos y de oportunidades de inversión, y la educación intercultural bilingüe. Han dado a la luz, además, algunos ensayos que argumentan su posición acerca de la utopía y la identidad andina o la agresión occidental ${ }^{48}$. En concordancia con la dependencia financiera del Estado, para el desarrollo de sus estudios (técnicos, socioeconómicos, evaluación de proyectos), muchos de estos profesionales se han organizado en empresas consultoras privadas. Destaca entre estos intelectuales el uso extensivo de las posibilidades abiertas por Internet, con la finalidad de difundir sus planteamientos, informarse de temas de su interés o comunicarse a través de redes más amplias que exceden el mundo estrictamente andino.

\section{Una mirada al pasado: historia y etnohistoria andinas}

En este campo se presenta una continuidad con los problemas de investigación que venían trabajándose sobre lo andino colonial. En la historia y etnohistoria regionales siguen trabajando activamente los profesores Jorge Hidalgo (1996a, 1996b, 1997, 1999-2000, 2003) ${ }^{49}$ y José Luis Martínez (1990a, 1990b, 1992a, 1992b, 1994, 1995a, 1995b, 1995c, 1996, 1998, 2000a, 2000b, 2000c, 2000d, 2002, 2003, 2004a, 2004b, 2004c, 2006). Aunque la influencia del primero en la formación de historiadores en la Universidad de Tarapacá declina considerablemente ${ }^{50}$, ambos contribuyen a formar e influencian a algunos nuevos investigadores egresados de pregrado y postgrado de las universidades de Chile, Valparaíso y Academia de Humanismo Cristiano. De esta manera, ha aumentado el número de profesionales trabajando sobre historia y etnohistoria andinas y se verifica una mayor diversificación de los temas tratados aprovechando el rescate de una más amplia información documental ${ }^{51}$. Destaca el empleo de la noción de identidad étnica para señalar la existencia de varios grupos étnicos en situación de coexistencia o para delimitar espacios de interacción y territorios. Asimismo, en el plano teórico y metodológico algunos de estos investigadores se distancian de supuestos positivistas y dan una creciente valoración a la historia interpretativa.

Como se ha mencionado, algunos antropólogos también han buscado dar profundidad temporal a sus investigaciones, incursionando en estudios antropológico-históricos. Es el caso de Héctor González en el tema de la constitución y desarrollo del sistema de propiedad de la tierra y de Hans Gundermann en la formación y transformación de la comunidad y los cambios históricos de la relación entre identidad étnica y ciudadanía en el norte de Chile ${ }^{52}$. A ellos se agrega el sociólogo Sergio González quien ha rescatado la presencia indígena en sus trabajos sobre el ciclo salitrero y la introducción de la escuela nacional chilena en el sector rural de Tarapacá. Con esta búsqueda se hace más evidente la necesidad de avanzar en la comprensión del siglo XIX y de la primera mitad del siglo XX, un período que historiadores $\mathrm{y}$ etnohistoriadores habían abordado insuficientemente, bajo el supuesto de que la comprensión de los procesos étnicos requiere situarlos en el contexto del desarrollo de la modernidad latinoamericana visible en el cambio 
del Estado colonial al Estado nación, en el surgimiento de las economías capitalistas de enclave, en el desarrollo del Estado republicano, etc.

\section{Vacíos y Desafíos en la Producción de Conocimiento Antropológico sobre Aymaras y Atacameños}

La producción de conocimiento sobre las sociedades andinas del norte de Chile manifiesta carencias y problemas. En este acápite se resumen algunos de estos vacíos y se proponen algunas orientaciones posibles de investigación que, a nuestro entender, son fundamentales para la continuidad y proyección de una antropología regional que mire hacia el siglo XXI. No se trata de una discusión exhaustiva; tampoco está exenta de nuestros énfasis y preferencias. De todas maneras, se apoyan en el examen de la trayectoria de la disciplina realizada más arriba, en nuestra propia experiencia de investigación y en una percepción razonable acerca de las condiciones para una antropología con más consecuencias de conocimiento.

Uno de los temas característicos de la investigación regional son las economías campesinas andinas. En la investigación sobre economía de la zona andina existe una gran cantidad de informes e investigaciones que tratan diversos aspectos. Algunos trabajos han abordado cuestiones centrales como la estructura de composición de los ingresos rurales y urbanos entre los aymaras y entre el campesinado atacameño de San Pedro de Atacama. Los mayores problemas se presentan con la ausencia de síntesis y la utilización de herramientas teóricas y metodológicas que no han permitido superar la dicotomía rural/urbano desde la cual se ha construido este tipo de conocimiento. Algo se ha avanzado en trabajos recientes con el empleo de la noción de translocalización económica. Este concepto, sin embargo, no termina de resolver las cosas, ya que si bien ayuda a considerar de mejor manera las relaciones y los espacios económicos regionales con presencia andina, no permite responder la desafiante pregunta sobre los sujetos económicos con los que actualmente debe tratar la antropología regional; por ejemplo, ¿qué son hoy, económicamente hablando, los atacameños de San Pedro de Atacama y sus ayllos o los numerosos residentes aymaras en la nueva comuna de Alto Hospicio, provenientes del altiplano y de una frontera relativamente "recalentada"?
La pregunta por la sociedad andina, por el vínculo social, tiene pendientes mejores respuestas. Sobre la organización social existe una abundante literatura compuesta de monografías de comunidades, aunque en general misceláneas y con análisis superficiales de las relaciones sociales, ya que temas clásicos en estos estudios, como la familia y el parentesco, tienen todavía una realización incipiente. En general, la temática de la comunidad andina está bastante más trabajada. La regionalización de la sociedad andina, la translocalización de las comunidades y la complejización del "lazo social" se han venido desarrollando en el último tiempo, pero faltan todavía publicaciones de mayor peso sobre la materia. Asimismo, se sabe casi nada acerca de las relaciones sociales andinas en los espacios urbanos, lo que es válido tanto al interior de los mismos contingentes indígenas como respecto de las relaciones interétnicas, temas fundamentales si se considera que hoy la mayor parte de los miembros de estos pueblos andinos sigue una vida urbana o fuertemente relacionada con ella. Por otro lado, si bien ya no es posible sostener una dicotomía rural/ urbano como la proveniente de la antropología de la comunidad y la sociología rural clásica, igual falta abordar las nuevas relaciones, redes y grupos emergentes de estas relaciones, responder la pregunta sobre qué habitantes rurales andinos son los que se están hoy formando.

Y si de sociedad y relaciones sociales se trata, una mirada más atenta muestra otros grandes vacíos en la antropología nortina, especialmente sobre tres temas a los cuales las ciencias sociales dan hoy gran importancia. Si bien se han iniciado estudios sobre las relaciones de género y existen las primeras publicaciones, todavía se trata de un campo de investigación incipiente y centrado casi exclusivamente en el caso aymara. Falta conocer más y mejor las relaciones entre hombres y mujeres, las prácticas de la sexualidad, la masculinidad y la identidad de la mujer andina, y la relación de lo anterior con las instituciones familiares y del parentesco ${ }^{53}$. Y para no correr el riesgo de anacronismo y caer en las ideologías de la andinidad sobre esta materia (como la teoría del chacha-warmi, por ejemplo), es indispensable situar las relaciones estudiadas en perspectiva de cambio y continuidad, especialmente si se consideran las profundas transformaciones sociales y los drásticos cambios ocurridos en los espacios sociales andinos.

Las relaciones generacionales y las categorías sociales derivadas han sido también tratadas de 
forma incipiente y dispersa. No se han desarrollado cabalmente los instrumentos conceptuales indispensables. Niñez, juventud, adultez o ancianidad son nociones cuya pertinencia de aplicación se debe todavía validar. Pero también se debe prestar adecuada atención a qué relaciones intergeneracionales, en qué grupos, en qué contextos sociales, a los de ayer o a los de hoy, qué es lo que tiene continuidad cultural y qué no, qué es lo nuevo. Al tenor de la drástica regionalización de las sociedades andinas en el último medio siglo y de las correlativas transformaciones sociales y culturales, es necesario indagar por sus efectos sobre estas relaciones sociales. Es necesario abordar las relaciones de autoridad entre generaciones y la capacidad actual de los adultos para incidir sobre las trayectorias de vida de los más jóvenes, como ocurría en el pasado. Relacionado a ello, se presenta la cuestión de la autonomía, de precisar en qué sentido se puede hoy hablar o no de un individuo "andino", luego de su paso por la escuela nacional, las sociabilidades urbanas y las valoraciones modernizantes. Tampoco se ha abordado la constitución de nuevas categorías sociales en los grupos andinos; por ejemplo, la de los adolescentes y su participación en culturas juveniles y en fenómenos como los de las pandillas. ¿Se trata de innovación neta en sociedades campesinas cuya organización social de las trayectorias de vida era muy diferente? Desde cierto punto de vista sociológico todo parece nuevo; pero, desde una mirada más cultural, son visibles las continuidades reelaboradas.

Falta mucha investigación sobre la experiencia urbana andina con los medios populares; sobre la integración regional y la subregional a través de los mercados y su incidencia en la redefinición social de las fronteras andinas; acerca de la reorientación económica aymara hacia el sector terciario de la economía, el trasporte y el comercio regional; sobre la posición del norte de Chile respecto de los grandes centros peruanos y bolivianos de producción de cocaína y derivados y participación andina en el tráfico de drogas (o en el de vehículos robados, como ha ocurrido en los últimos años). Todos estos fenómenos pluralizan las experiencias y los patrones sociales, gestan nuevas oportunidades, ponen en tensión principios éticos, relativizan los límites de lo moralmente reprochable, vulneran las fronteras de lo permitido, gatillan acciones $\mathrm{y}$, en definitiva, involucran a individuos, familias y redes andinas en prácticas que algunas veces bordean o definitivamente traspasan los márgenes legales. Existe apenas un estudio que atiende aspectos puntuales de este ámbito de fenómenos de evidente importancia social y política, sobre el tráfico de estupefacientes entre los aymaras.

En el campo del poder, la política, la representación colectiva, la organización, la demanda al Estado y otros temas similares, tampoco se ha avanzado suficientemente. Se han inventariado y tipologizado organizaciones y se ha trabajado la relación entre etnicidad y ciudadanía, y el conflicto en torno a la tierra. La participación política ha sido apenas comentada a propósito del término del gobierno autoritario y, recientemente, se ha abordado la relación entre municipio, gobiernos locales y etnicidad, pero se conoce poco sobre las estructuras de poder interno en las comunidades, de los sistemas de autoridad y liderazgo, de la conflictividad y los mecanismos de mediación social, de la cultura política, de los "pactos de dominación" vigentes y otros temas parecidos. Por ejemplo, de qué naturaleza es la demanda andina en el siglo XX al Estado chileno, cuáles son sus transformaciones, qué relación guarda ello con los sujetos sociales andinos, qué vínculo hay hoy entre la demanda local y la étnica. Y cuando se habla de cultura política, de qué se trata: ¿de ciudadanía, de regímenes de clientelismo o qué?

Los fenómenos religiosos han sido poco y mal tratados. Se ha estudiado el cambio religioso en sectores puntuales, sólo en Colchane y en Putre; las divinidades naturales y el esquema cosmológico; incluso, se ha levantado toda una ideología sobre la cosmovisión aymara. Últimamente se ha abordado, además, el rol de la religión en las relaciones de género. Sin embargo, todavía falta considerable trabajo, tanto en amplitud geográfica (ya que sobre muchas zonas andinas se sabe casi nada en esta materia) como en profundidad histórica. Por ejemplo, la historia del protestantismo entre los aymaras se inicia a principios de siglo XX, sin que este hecho se haya abordado o incorporado al análisis y la discusión. En general, la investigación no se ha abierto a nuevas dimensiones, tales como la religiosidad andina urbana, la relación entre religión y sociedad (superando la manida tesis de la "anomia"), el nexo entre ethos andino y religión rediscutiendo el tema desde posiciones más objetivas; la emergencia de un neotradicionalismo religioso y otras cuestiones de similar importancia. 
Quizás el tema de la cultura sea el más pobre, deficitaria y sesgadamente tratado. Aparte de la religión, por lo demás imperfecta e insuficientemente abordada (véase supra), se puede decir que la cultura ha sido estudiada sólo muy fragmentariamente. Faltan esfuerzos dirigidos a la elaboración o aplicación de conceptos más específicos, ya que se trata de un campo muy amplio de fenómenos que, además, no tiene la condición unitaria que pudo poseer antaño. Es imperativo, entonces, atender algunas distinciones mínimas. Si la cultura actual es heterogénea, esa heterogeneidad se debe cualificar. Si la cultura es ante todo sentido, significado, "dimensión simbólica de lo social" según la afortunada frase de Giménez (1987), sus portadores son sujetos sociales. Se ha aludido a la diversidad actual de los sujetos andinos $\mathrm{y}$, como consecuencia, la correspondiente pluralidad de repertorios de sentido que se ponen en juego en la vida social. Desde esta perspectiva analítica, resulta más adecuado hablar de repertorios culturales andinos, de los sujetos, antes que de culturas al estilo de la visión antropológica convencional.

Es de gran interés explorar las fuentes desde las que históricamente los sujetos andinos se han nutrido de significados que, una vez reelaborados socialmente, se transforman en contenidos, referencias o núcleos de sentido en que se apoyan continuidades e innovaciones, en una cadena sin fin. Estas fuentes de significados son diversas, pero es posible mencionar algunas, y con ello denotar la considerable ignorancia que existe sobre las mismas. Por cierto, las culturas locales o comunitarias, donde se encuentra todavía la base, el soporte social de la unidad cultural andina y donde se encuentra la mayoría de las instituciones culturales que le entregan una fisonomía particular a estas sociedades ${ }^{54}$. Otra es la cultura nacional, inculcada sobre todo desde los medios escolares, una institución cultural cuyo impacto se ha señalado, pero sobre la cual todavía persisten diferencias de interpretación acerca de su importancia. También las fuentes provenientes de las culturas populares obreras y urbanas, con las que las sociedades andinas han mantenido una intensa y centenaria relación. Asimismo, lo que se podría denominar como cultura andina subregional, especialmente aquella que, entre otras posibilidades de circulación, se difunde y desarrolla en formato de industria cultural (por ejemplo, alrededor de la primera mitad del siglo XX los waynos andinos a través de los discos de vinilo y los gramófonos o, en el presente, la llamada "cumbia andina"), demostrando que la reproducción cultural andina no necesariamente está reñida con las formas modernas de producción y circulación de cultura. Otro gran ámbito es aquel constituido por el amplio espectro de la cultura de masas, que se puede ejemplificar con la influencia actual de la televisión en una población indígena mayoritariamente urbana y con un contingente juvenil muy importante. Otras fuentes, más especializadas y marcadas por su dinamismo, son los repertorios culturales juveniles, entre los que se encuentran las identificaciones relacionadas con el consumo, las modas, la música, etc.; las que introducen la necesidad actual de diferenciar entre adopciones culturales perdurables y efímeras, una cuestión que no se presentaba de igual modo en las sociedades andinas del pasado.

Pero cultura no es sólo significado interiorizado y objetivado en prácticas, definibles luego como económicas, sociales o políticas. Externamente se aprecian ciertas manifestaciones sociales como propiamente culturales (por ejemplo, ceremonias, fiestas, medicina). Internamente, en tanto, esas y otras prácticas se entienden mediante nociones a veces cercanas a la idea antropológica de cultura. Cuando las propias sociedades andinas antes se referían a las "costumbres" o cuando ahora utilizan los conceptos de "cultura" aymara, quechua o atacameña, se identifica un conjunto de prácticas como un plano, dimensión o esfera que sin dificultad calificamos de cultura. Por lo demás, algunas de las distinciones vigentes en este campo han incorporado ideas provenientes de los discursos de la diferencia: así surgen y hacen sentido términos como los de "patrimonio cultural", "identidad cultural", "herencia cultural". Otra manera de consignar estos cambios es señalar el carácter crecientemente consciente, público y político de instituciones y prácticas que antaño se vivían de manera menos reflexiva.

¿Qué se tiene y qué se sabe entonces sobre el tema de la cultura en las sociedades andinas regionales? Se podría decir que sólo retazos unidos por un hilo bastante débil: la tesis de una unidad e integración cultural andina. Se conoce bien algunos de esos fragmentos, y las obras que los describen, analizan e interpretan se encuentran entre las piezas mejor logradas de la antropología nortina. Pero del resto, buena parte de lo que se ha escrito es incipiente, superficial o descontextualizado; presenta vicios o falacias (como las del internalismo, el "estructurismo" o "desestructurismo", por ejemplo); son metodológicamente insuficientes o 
sustentan tesis de base insolubles ${ }^{55}$. Las tareas por emprender en este ámbito son desafiantes. A título ilustrativo, se pueden proponer cuatro materias que debieran integrar un programa de investigaciones culturales andinas. Las tres primeras caen dentro de lo que se puede definir como prácticas culturales institucionalizadas; la cuarta, en tanto, remite a parámetros de significado a partir de los cuales los sujetos andinos se definen y orientan aspectos de su acción.

Primero, la medicina andina o el conjunto de conocimientos, prácticas, actores y sistemas médicos de los que participan los sujetos andinos, proporcionan uno de los ejemplos más notables de continuidad cultural. Sin duda, se ha ampliado, enriquecido y, con ello, complejizado el repertorio de ideas, prácticas y sujetos médicos, pero se ha mantenido una considerable fidelidad cultural. De esta manera, actualmente los yatiri son posiblemente más abundantes en los medios urbanos que en las comunidades campesinas. $\mathrm{Al}$ amparo de iniciativas tendientes a articular una medicina intercultural, se dispone de los primeros estudios ${ }^{56}$, pero ello sólo se puede considerar como una apertura de campo.

Segundo, en la música andina actual se asiste a una intensa creación y masificación musical, unido a la incorporación de tecnología electrónica. Estos cambios tienen también un impacto visible sobre algunos aspectos de las festividades tradicionales. La música "chicha" o "cumbia andina", surgida en los medios urbanos del espacio cultural andino trasnacional articulado por las ciudades de La Paz, Cochabamba, Tacna, Arequipa, Lima y Arica, tiene hoy una gran convocatoria popular. Ella sintetiza elementos de varias tradiciones musicales, entre las cuales se encuentra la de los sentimentales wainos. La continuidad cultural se da aquí no con la pura permanencia de prácticas culturales, sino que a través de una activa creatividad cultural que integra en nuevas manifestaciones elementos tradicionales y foráneos ${ }^{57}$.

Tercero, como se dio a entender arriba, resulta notable la importancia social y política actual de la cultura andina (o de su apelación, para ser más precisos), como fundamento en la formulación y reproducción de la diferencia étnica. Los fenómenos de etnogénesis y etnificación de la última década y media tienen como pieza central, precisamente, la noción antropológica de cultura y el relativismo asociado, por el cual todas las culturas son irreductibles unas a otras y están investidas de igual dignidad y valor. Sin embargo, hasta ahora no existe un estudio que tome como asunto principal el campo semántico andino para este concepto incorporado, las prácticas que los sujetos orientan con su concurso, sus usos retóricos, su valor político $\mathrm{y}$ otros temas similares.

Cuarto, los sujetos andinos de la antropología de hoy no son los mismos que antaño. Ello es así no sólo porque hayan cambiado los intereses o enfoques de la disciplina, sino también porque han ocurrido cambios en la definición y la posición de los sujetos andinos ${ }^{58}$. La definición de sujeto que prevalece actualmente es étnico cultural: "aymara", "atacameño", "quechua", "coya". De todas maneras, ello no impide la vigencia o, al menos, latencia de otras inscripciones sociales de sujeto: "pobre", "campesino", "guardián de la frontera" y otras. Se debe consignar también que esas posiciones de sujeto se ajustan a parámetros de espacio y tiempo social diversos: espacialidades míticas y políticas (como territorio), o temporalidades religiosas, del sentido del cambio como progreso, etapas de vida, utopías, etc. En general, de todo esto se sabe muy poco.

\section{Conclusiones}

Las conclusiones se han organizado según dos ejes: uno de síntesis que intenta explicitar los distintos sujetos que la antropología del norte ha "postulado" o "construido" como objetos de estudio; y otro más normativo, en que se proponen algunos principios y criterios para potenciar una práctica antropológica regional de cara al siglo XXI.

\section{Los sujetos de la antropología del norte}

En la extensa presentación anterior se ha hablando de objetos antropológicos y de antropólogos en posición de sujetos que formulan conocimientos $^{59}$. En el norte de Chile, el objeto principal de la práctica antropológica son los pueblos indígenas, "el indio" o el "hombre andino"; no hay una antropología regional de otros sujetos que no sean aquellos genéricamente conocidos como "andinos". Se insistió también en que estos objetos son relativos a las tomas de posición de los investigadores y, más allá, a las escuelas de pensamiento por las que son influidos. En extremo, se podría plantear que habrá tantos objetos como antropologías que los hayan constituido a través de su acción intelectual, aunque no siempre es cierta una correlación 
término a término. Entendiendo que estas visiones y posicionamientos no se desarrollan o aplican en un vacío social, a las entidades sociológicas propuestas por ese quehacer constructivo corresponden sujetos sociales más o menos definibles o difusos, según los casos. En esta medida, la relación entre sujeto y objeto antropológico es compleja y se debe explicitar en cada caso. Por otra parte, estos sujetos no son específicos a esta región, sino más bien relativos a tradiciones intelectuales y escuelas antropológicas. En la labor constructiva se han tomado en préstamo conceptos, categorías y representaciones aplicadas o provenientes de otras partes, que se han adecuado para reconocer a los sujetos regionales.

Según se puede colegir del repaso de los distintos estudios que se han realizado sobre los grupos andinos del área, los sujetos antropológicos más importantes que se han construido son los siguientes:

\section{Los pueblos relictuales}

Esta adjetivación, de origen botánico, parece ser la más adecuada para caracterizar la forma de apreciar, diagnosticar y valorar las poblaciones indígenas regionales que entregan los etnólogos, arqueólogos y otros profesionales interesados en estos pueblos, desde la mitad del siglo XIX hasta mediados del siglo XX. La idea predominante es la de grupos sobrevivientes del pasado, reducidos espacialmente a los márgenes geográficos de la región, disminuidos numéricamente, prontos a ser asimilados y, por tanto, condenados a desaparecer. Es una visión pesimista acerca del futuro indígena, por lo que los conocimientos que se generan tienen el sabor del rescate cultural. Para explicar su presencia y estado, se aplican nociones de origen difusionista (hipótesis históricas de génesis, distribución, intercambio y préstamos culturales) y evolucionista (grupos que han quedado fuera de su curso central por la propia historia y la civilización). Estas interpretaciones consideran enormes lapsos de tiempo y cubren extensas regiones geográficas.

Es bueno señalar que los grupos interpelados tenían de sí mismos una visión bastante diferente de la propuesta por etnógrafos y otros estudiosos que escribieron sobre ellos. Con importantes variaciones según los grupos y los sectores, éstos se ubicaban al interior de lo que hemos llamado el "paradigma semántico del indio": grupos que por sus formas de vida y condición social se encuentran en el extremo más tradicional y atrasado de la sociedad.
De esta manera, el objeto antropológico y el sujeto soporte de esas representaciones guardaban entre sí una distancia abismal. No obstante, como se puede apreciar desde la actualidad, es una antropología que produce distinciones y definiciones que décadas más tarde serán la materia prima de fenómenos de clasificación y tipificación étnicas.

\section{La comunidad indígena}

Un segundo enfoque antropológico que corre con éxito desde la década de 1950 en adelante y mantiene vigencia parcial hasta hoy, es el de la comunidad campesina indígena. Tiene su origen en la reorientación del objeto de la antropología que se lleva a efecto en muchos lugares del mundo, luego que las sociedades de Outre mer fueran crecientemente integradas a los sistemas estatales nacionales y globales (Kearney 1996). El campesinado, sus localidades y comunidades serán en lo sucesivo un objeto preferente de la disciplina, por lo menos en las áreas nucleares de Latinoamérica (Mesoamérica y los Andes). De esta manera, el conocimiento buscado por la antropología se resolverá en las instituciones locales comunitarias y en la vida pueblerina.

Se ha discutido mucho el carácter funcionalista, internalista y por tanto descontextualizado del conocimiento logrado por la investigación orientada de esta manera. Los grupos sociales objeto de esta antropología aparecen, con más frecuencia de la deseada, asépticos o indemnes por relación al capital industrial y comercial, a los mercados de fuerza de trabajo, a las formas de dominación tradicionales, a la acción desarrollista del Estado. De esta manera, la explicación de su realidad y de su dinámica queda en buena medida librada a las instituciones y las fuerzas sociales internas. El momento histórico que se vive en América Latina y en Chile corresponde al del desarrollo capitalista endógeno, con una creciente integración de territorios y poblaciones nacionales. Es un momento también de luchas sociales (campesinas) y reformas (como la agraria), de las cuales los indígenas no estuvieron exentos. Nuevamente aquí, el objeto antropológico sostiene una relación contradictoria con el sujeto de conocimiento: mientras estos se conforman en las relaciones externas (movimientos sociales, desarrollismo, reforma agraria), esta antropología los constituye como un objeto del que se privilegian sus dimensiones internas. 


\section{El hombre andino}

Constituye una de las representaciones de sujeto más influyentes en la década de 1970 y de 1980 en los estudios antropológicos del norte de Chile. Incide posiblemente más en los arqueólogos y etnohistoriadores nacionales que en los antropólogos. El alcance de la propuesta es bastante amplio, subregional. Surge y se desarrolla desde los estudios etnohistóricos, etnológicos y, en menor medida, arqueológicos efectuados en los países andinos por parte de algunas misiones científicas norteamericanas. A ellas se pliegan con prontitud investigadores europeos y antropólogos locales, a medida que la disciplina se institucionaliza en los países andinos. Uno de sus grandes atractivos radica en el esfuerzo por identificar continuidades de las lógicas sociales, instituciones, patrones culturales, prácticas y relaciones económicas de los pueblos indígenas andinos actuales con los del pasado, sea en términos de persistencia o de reelaboración.

Se trata de una perspectiva antropológica igual de internalista que la que se ocupa del estudio de la comunidad de campesinos indígena. Pero, en este caso, el sujeto andino no se define por una recontextualización histórica (integración colonial, campesinización de las economías étnicas, etc.), sino por su pertenencia a un espacio civilizatorio: el andino. Contiene en esta medida el presupuesto, al menos en ciertas áreas y circunstancias, de un sujeto con capacidad para perdurar históricamente en el largo plazo. No desconoce los contextos socio-históricos, pero no los privilegia. Uno de los mayores problemas de esta construcción del objeto antropológico lo representa la dificultad de incorporar plenamente las discontinuidades sociales e históricas y la transformación, a veces de gran alcance, de los sujetos que surgen y se transforman en los avatares históricos regionales. La polisemia de su cultura, la hibridez de sus prácticas, la novedad de algunas de sus relaciones sociales, la modernidad de algunas formas de organización, la heterogeneidad de su sociedad, las contradicciones que recorren su vida social, la complejidad de las ecuaciones entre tradición e innovación, todo tiende a diluirse o quedar en un plano lejano.

Representaciones de este tipo han conducido a argumentaciones y planteamientos realmente forzados. Este es el caso de la tesis de la "desestructuración" andina regional, cuyo postulado supone un estado previo de "estructuración" y ese estado inicial se tiende a plantear en la larga duración, incluso prehispánica. La contextualidad sociohistórica y de los sujetos andinos se debilita a tal punto que la historia se hace inocua, aunque sólo hasta el momento en que irrumpe la modernidad y empieza la "desestructuración" o el "holocausto al progreso". Se trata, entonces, de un enfoque crítico de la modernidad en los Andes, pero complaciente y conservador en cuanto a la prolongada y agitada historia anterior. Aunque indirectamente, la antropología del hombre andino también influyó en que no se desarrollara una antropología de las relaciones con el Estado, como ocurre en el sur del país respecto del pueblo mapuche. Ésta sólo aparecerá a fines de la década de 1980, pero sin que se resuelva en la construcción de un nuevo sujeto; quizá por la debilidad de los movimientos sociales andinos y por el avance logrado por la representación de un nuevo objeto-sujeto antropológico: el de los pueblos originarios.

\section{La de los pueblos originarios}

La etnia, el pueblo y, a veces, la nación son los conceptos de constitución del sujeto de conocimiento más recientes dentro de las preocupaciones de la antropología nortina. Este sujeto y la antropología que lo observa -y a veces lo acompaña- guardan entre sí una antigua complicidad: la que proviene de la adopción y naturalización, por unos (los intelectuales, líderes y dirigencias aymaras, atacameñas, quechuas y coyas), de la representación que se había forjado respecto de su objeto la primera antropología ("culturas" en estado de supervivencia). Con ello no se quiere plantear una relación de paternidad de la antropología en la formulación de estos nuevos sujetos étnicos, sino simplemente consignar un nexo anterior al momento reciente en que la antropología aborda estos nuevos sujetos indígenas. Como se sabe, esta nueva realidad de sujeto se conforma sólo en las últimas décadas, con la concurrencia de un conjunto de factores: emergencia de nuevos tipos de movimientos sociales en un escenario de intensificación de la globalización, expansión de una sensibilidad cultural por la diferencia, generación de nociones jurídicas y políticas que promueven el reconocimiento de minorías lingüísticas y culturales y de grupos nacionales subordinados. En Chile específicamente, concurren la acción de organismos no gubernamentales opositores al gobierno autoritario, la sensibilización de estos temas en una parte de la 
clase política en el escenario de post-dictadura y la redefinición de los movimientos indígenas nacionales, en particular el mapuche, entre los factores más importantes.

Es indispensable destacar que por primera vez se estaría dando un encuentro entre un sujeto social (los pueblos o etnias andinas) y un objeto antropológico. Y esto de dos maneras: por el modo en que cierto número de antropólogos define el sentido del conocimiento: en la estela de "una antropología de apoyo"; y por la orientación de la investigación: preferentemente en temas de índole socio-política. De ello deriva una práctica antropológica marcada por la urgencia, donde el sello característico es la presencia con y la utilidad del conocimiento generado para los sujetos. Ciertamente, existen matices según los autores, pero esta parece ser la nota predominante en esta inédita convergencia entre sujetos sociales y objeto antropológico en esta nueva forma de antropología de cara al siglo XXI.

\section{Algunas condiciones para una práctica antropológica revisada}

El recuento de la producción de conocimiento antropológico sobre aymaras y atacameños en el norte de Chile no sólo enseña acerca de la constitución de sujetos, sino también vacíos, carencias y desafíos. La materia que se trató de sistematizar es una realidad construida en una relación dinámica entre varios términos. Por un lado, la formación de la ciencia antropológica en el país (a la zaga de los procesos de conformación disciplinaria mundial). Por otro, la construcción de objetos intelectuales, en una vinculación real, pero no siempre directa ni clara, con los fenómenos de la modernidad y los procesos de modernización. Por último, el mismo flujo de lo social andino y de sus sujetos, envueltos en esos procesos modernizadores y abordados en esa relación por una práctica antropológica sometida a parámetros disciplinarios.

Esta antropología no sólo es del norte, sino también "andina". Lo ha sido y será por acción, ya que, aunque varíen los principios sobre los cuales se asienta la construcción de objetos (cf. la tipología de sujetos antropológicos propuesta más arriba), todos remiten o tienen por referencia la macrorregión andina y su historia socio-cultural. Y ha sido andina también por omisión, puesto que sólo recientemente se han empezado a abrir otros campos de construcción de objetos de conocimiento (antropología médica, antropología de la educación, etc.), donde los pueblos indígenas son sólo uno entre otros de los posibles sujetos colectivos a conside$\operatorname{rar}^{60}$. Pero cómo se debe abordar lo andino: ¿como continuidad cultural objetiva o como una realidad de grupos portadores de proyectos de cambio orientados a reforzar diferencias culturales?

La primera opción enfrenta problemas importantes de definición y delimitación respecto de una realidad social regional bullente y en rápida transformación: ¿qué es efectivamente esa continuidad si se acepta la necesidad ineludible de considerar los ambientes sociales en que los sujetos despliegan su acción y su contextualización socio-histórica?; ¿qué capacidad de perdurar puede tener lo andino, si no es a través de las sucesivas transformaciones que los reconfiguran como sujetos y realidad sociales? La segunda opción, aunque participa de una ética científica de compromiso con la diferencia que actualmente goza de una aceptación y legitimidad posiblemente inédita, presenta problemas de unilateralidad, reduccionismo y subjetivismo. Se privilegia, a veces de manera no justificada, una visión y perspectiva de análisis acerca de la diferencia, en circunstancia que es más prudente considerarla sólo como una posibilidad interpretativa entre otras. Por otro lado, la sobredeterminación conceptual de la diferencia acarrea el riesgo de empobrecer la materia cultural, sociológica e histórica que se debe interpretar. Finalmente, al privilegiar la discursividad social (fraseada muchas veces como la "voz del otro" negada históricamente), deja sin despegue el segundo momento de conocimiento, esta vez objetivante, en que se integran esas voces en una síntesis interpretativa capaz de resolver la relación entre esa discursividad, los sujetos que las portan y producen en ambientes sociales y políticos dados, y en contextos sociohistóricos determinables.

El concepto de lo andino es un recurso metodológico importante, si se le entiende como un concepto límite que ayuda a pensar e investigar. Se puede considerar como el postulado de una unidad mínima, a la vez histórica y antropológica, de poblaciones y grupos cuyo origen es prehispánico. Correspondería, por así decirlo, a la cara continuista del enfoque que se propone. Pero no necesariamente para encontrar su persistencia, sino hasta incluso para negarla o consignar su ausencia, su transformación o su fusión. Es un concepto referencial, una herramienta conceptual útil para la definición de un objeto posible. Su base objetiva no es otra cosa 
que la eventualidad de la continuidad socio-cultural, que requerirá siempre de confirmación.

No se puede desconocer la existencia de objetos, tecnologías y prácticas que, muchas veces en anonimato, han perdurado por siglos. Pero es también irrecusable la pregunta por su vigencia e importancia social presente. De aquí entonces la necesidad de una etnografía de los sistemas sociales y los sujetos del presente. Esto no significa avalar una etnografía carente de contexto o de historia, sino insistir en que no puede ser una etnografía de la supervivencia o la reminiscencia, incapaz de abarcar la riqueza social y cultural de los fenómenos del presente. No hay dudas que puede ser de interés a la hora de pretender trazar lazos de permanencia en el tiempo, pero se debe reparar que con ello se atiende una entre muchas preguntas dignas de atención, y no siempre ni necesariamente la más importante.

Asimismo, los desafíos futuros de conocimiento no se resuelven con una antropología funcionalista de los sistemas institucionales; no por ausencia de fenómenos que puedan ser descritos de ese modo, sino porque esta perspectiva es incompleta e insuficiente. La necesidad de conceder primer plano el actor es mucho más que una concesión al enfoque hoy en boga de la agencia. Es una condición indispensable de conocimiento: los actores sociales reproducen y crean, por lo común sin saberlo, sistemas sociales y estos se constituyen como parámetros relativos para la acción de los agentes sociales. Sólo así es dable apreciar sujetos activos y creativos que intervienen sobre sus circunstancias, buscando moldearlas en dirección de metas individuales o sociales.

Los sujetos no son entes inermes ante las fuerzas de las instituciones y los sistemas sociales que los envuelven y en parte importante los modelan. No cabe ni un determinismo reductor, ni la irresponsabilidad de asumir la sociedad y la cultura como mera contingencia. La antropología regional requiere prestar más atención a esta dimensión si aspira sacudirse de tesis en que los sujetos andinos perecen irremediablemente aplastados por el peso de los grandes sistemas institucionales de la modernidad, el Estado y el mercado, o al revés, empecinados en una continuidad cultural centenaria. Por el contrario, siempre será más provechoso atender lo que lo social andino pueda tener de determinado, pero también de contingente; conceder tanta importancia a la subjetividad y lo que ella moviliza en los actores, como al contexto social de los mismos y a su incidencia; al carácter racional y consciente, tanto como a los valores y creencias que intervienen en la vida social; a la importancia de los ambientes y eventos en que se movilizan los actores, como al peso de la historia.

Consideramos, entonces, que una antropología social de los grupos regionales andinos debe abordar los sujetos sociales de hoy y de ayer en una triple relación que considere: primero, sus contextos inmediatos de acción e interacción (comunidades, barrios, grupos parentales, círculos sociales, instituciones y grupos, redes económicas, etc.); segundo, los procesos regionales y las fuerzas estructurales que pesan sobre ellos (los mercados de fuerza de trabajo, las políticas estatales, los procesos de transformación social, la irrupción de la cultura de masas, los cambios en los patrones de consumo, la movilidad social, los procesos de constitución y transformación de sujetos sociales, etc.); y, tercero, esas mismas fuerzas y procesos vistos en perspectiva histórica o diacrónica. El primer plano correspondería a la dimensión interna del análisis, en tanto que los dos últimos, en conjunto, conforman el análisis externo o de contextualización socio-histórica de los agentes sociales (Thompson 1990).

¿Cuáles pueden ser los objetos antropológicos del siglo XXI? No es dable saberlo porque, como se ha insistido, resultan siempre de una relación entre escuelas antropológicas y sujetos sociales en un momento histórico dado. Sí se puede aseverar algo más general: que dadas la pluralidad de las orientaciones disciplinarias y la diversidad de actores sociales andinos actuales y en gestación, difícilmente podrá surgir una referencia antropológica unitaria. Se puede pronosticar que tendremos más bien objetos de conocimiento plurales y en situación de coexistencia. Cualquiera sea el caso, si la antropología regional quiere avanzar, debe aceptar la transformación radical de su objeto (de los sujetos sociales andinos). Pero también debe ir un paso más allá para destacar que las propias condiciones de formación de los sujetos sociales han cambiado por relación al pasado.

Para abordar los desafíos que plantean estas nuevas bases de formación de lo social y la complejidad y pluralidad de los sujetos sociales andinos, la antropología debe crear o tomar prestadas las herramientas teóricas y metodológicas más apropiadas. Sin embargo, es muy probable que esta antropología crítica que cuestiona las figuras preestablecidas o ideologizadas de lo andino y aborda sujetos colectivos cambiantes, dinámicos, 
complejos y heterogéneos, no sea bienvenida por el Estado y por las propias elites indígenas, aunque por razones diferentes en cada caso. Para el primero, significaría un rediseño de las políticas públicas y un reordenamiento de su labor, una cuestión muy difícil de asumir, no sólo por sus implicancias económicas y políticas, sino también por razones culturales. Entre los segundos, porque ante la necesidad de constituirse imaginariamente como actores étnicos, han elegido visiones "primordialistas" y "tradicionalizantes", alejadas de una modernidad a la que discursivamente se ha puesto al otro lado de la trinchera. Esta antropología regional tiene el desafío de romper con los estereotipos acerca de lo andino. Lo andino real debe dejar de ser sistemáticamente invisibilizado, para ser problematizado en toda su complejidad actual.

Agradecimientos: Este trabajo es parte de los resultados del proyecto Fondecyt $\mathrm{N}^{\circ} 1060973$. Agradecemos a los consultores anónimos por sus sugerencias. Dedicamos este trabajo a la memoria de Gabriel Martínez por sus propias luces y en representación de todos los estudiosos desaparecidos que han permitido la existencia de la antropología regional que aquí se aborda.

\section{Referencias Citadas}

Aguilera, R.

2002 Las Representaciones Sociales del Estado que han Configurado los Andinos del Norte de Chile. Tesis de Licenciatura en Sociología, Departamento de Ciencias Sociales, Universidad Arturo Prat, Iquique.

Aguirre, $\mathrm{O}$.

1995 La Comunidad Campesina Andina: el Caso de Chiapa, Quebrada de Aroma, en la I Región de Chile. Tesis de Licenciatura en Antropología, Escuela de Antropología, Universidad Austral de Chile, Valdivia.

Alaez, A.

1999 Duelo andino: sabiduría y elaboración de la muerte en los rituales mortuorios. En Los Vivos y los Muertos. Duelo y Ritual Mortuorio en los Andes, editado por J. van Kessel, pp. 211-224. IECTA, Iquique.

2001 Duelo andino: sabiduría y elaboración de la muerte en los rituales mortuorios. Chungara Revista de Antropología Chilena 33:173-178.

Albó, X.

2000 Aymaras entre Bolivia, Perú y Chile. Estudios Atacameños 19:43-73.

Albornoz, I.

1977 Antecedentes sobre Estudios de Suelos y Aguas del Sector de Isluga, Altiplano Tarapaqueño. Centro Isluga, Universidad del Norte, Iquique.

Aldunate, $\mathrm{C}$.

1985 Desecación de las vegas de Turi. Chungara 14:135139.

Aldunate, C., J. Armesto, V. Castro y C. Villagrán

1981 Estudio etnobotánico en una comunidad precordillerana: Toconce. Boletín del Museo Nacional de Historia Natural 38:183-223.

Aldunate, C. y V. Castro

1981 Las Chullpa de Toconce y su Relación con el Poblamiento Altiplánico en el Loa Superior. Tesis de Licenciatura en Filosofía, Mención en Prehistoria y Arqueología, Departamento de Ciencias Sociológicas y Antropológicas, Universidad de Chile, Santiago.

Aldunate, C., V. Castro y V. Varela

2003 Oralidad y arqueología: Una línea de trabajo en las tierras altas de la Región de Antofagasta. Chungara Revista de Antropología Chilena 35:305-314.
Alexander, J.

1990 La centralidad de los clásicos. En La Teoría Social Hoy, A. Giddens, J. Turner y otros, pp. 22-80. CONACULTAAlianza Editorial, México.

Alvarado, L.

1970 La Vida Rural en el Altiplano Chileno. ICIRA, Santiago.

Álvarez, L.

1987 El mito de Pusiri Collo y la fiesta del Pachallampe: aculturación andino-hispana en el poblado de Socoroma. Diálogo Andino 6:79-90.

1990 Etnopercepción Andina del Espacio: Valles Dulces, Valles Salados. Tesis para optar al grado de Magíster en Historia, Mención en Etnohistoria, Escuela de Postgrado, Facultad de Filosofía y Humanidades, Universidad de Chile, Santiago.

1991 Etnopercepción andina: valles dulces y valles salados en la vertiente occidental de los Andes. Diálogo Andino 10:9-20.

1992 Lo dulce y lo salado: dos formas de percepción en los Andes, Tiawanaku e Inca. Etnicidad, economía y simbolismo en los Andes. III Congreso Internacional de Etnohistoria. Coroico, compilado por S. Arze y R. Barragán, pp. 147-161. HISBOL-IFEA-SBH-ASUR, La Paz.

1997a Ocupación etnoandina del espacio en valles dulces y valles salados del extremo norte de Chile. Actas del Segundo Congreso Chileno de Antropología, Tomo II, pp. 556-558. Colegio de Antropólogos de Chile, Santiago.

1997b Relatos y tradiciones orales andinas. Sireno: dios de la música. Diálogo Andino 16:49-59.

1998 Documentos para una historia regional. Diálogo Andino $17: 19-49$.

Álvarez, J.

1987 Educación para el desarrollo andino. Una propuesta curricular bicultural para las escuelas aymaras de Tarapacá. Cuadernos de Investigación Social $\mathrm{N}^{\circ} 24$, Centro de Investigación de la Realidad del Norte, Iquique.

1989a El rol de la escuela en la comunidad indígena. Pueblos Indígenas y Educación 11:7-20.

1989b Una alternativa educacional bilingüe-bicultural para las comunidades aymaras del norte de Chile. En La visión india: tierra, cultura, lengua, derechos humanos (Simposio), varios autores, pp. 468-477. Musiro, Leiden. 
1990 Estrategias de desarrollo andino para Tarapacá. Instituto de Desarrollo Andino, Iquique.

1991 Chile: experiencias de educación étnica. En Etnias, Educación y Cultura, editado por D. González, pp. 141-148. Nueva Sociedad, La Paz.

1995 Plan andino de desarrollo integral para los Aymarás de Tarapacá. En Tierra, Territorio y Desarrollo Indígena, varios autores, pp. 223-226. Instituto de Estudios Indígenas, Universidad de la Frontera, Temuco.

2000 Jach'a mamanaj tatanaj layrapachat jiwasaru arusiri. Nuestros Sabios Abuelos nos Hablan de Tiempos Antiguos. Corporación Nacional de Desarrollo Indígena, Iquique.

2002 La fiesta religiosa andina en la provincia de Iquique: una inventarización. En Catastro del Patrimonio Cultural de la Provincia de Iquique, Región de Tarapacá, compilado por L. Núñez y C. García Huidobro, pp. 201-218. Minera Doña Inés de Collahuasi, Corporación Patrimonio Cultural de Chile, Santiago.

Andaur, $\mathrm{C}$.

2004 Historia de las Comunidades Andinas de Tarapacá: 1859-1900. Tesis para optar al título de Profesor de Historia y Ciencias Sociales, Instituto de Historia y Ciencias Sociales, Universidad de Valparaíso, Viña del Mar.

Anta, J.L.

1997a El contacto con el otro. Antropología y sincretismo en Atacama (Chile). Gaceta de Antropología 13 [http//www. ugr.es/ pwlac/G13_07JoseLuis_Anta_Felez.html]

1997b La fiesta de la Candelaria: tradición y modernidad en Atacama. Quaderns de l'Institut Català d'Antropologia 10:71-92.

1998 Atacama de Fin de Siglo: Tres Historias de Vida y una Biografía. Universidad de Jaén, España.

Aranda, X.

1964 San Pedro de Atacama. Elementos diagnósticos para un plan de desarrollo local. Informaciones Geográficas, Años XI-XIV:19-61 (número especial).

Aranda, X., R. Barahona y R. Saa

1968 Elementos Diagnósticos para un Plan de Desarrollo Local en San Pedro de Atacama. CORFO-Universidad de Chile, Instituto de Geografía, Santiago.

Aránguiz, G.

2004 Cariquima: una Experiencia de Mediación en la Construcción de Espacios Comunes. Tesis para optar al título de Antropólogo Social, Departamento de Antropología, Universidad de Chile, Santiago.

Araya, M.

2003 Fiscalidad y economía regional: Arica 1759-1799.

Chungara Revista de Antropología Chilena 35:141-157.

Arévalo, P.

1993. Valle de Camarones: Fronteras sur en la percepción de un espacio funcional andino. Revista Frontera 12:109119.

Arratia, M.

1991 Cultural action and cultural synthesis? Participatory methodologies and the Aymara of Northern Chile. Doctoral Dissertation, York University, Toronto.

1992-1993 Problemas conceptuales de la antropología y sus implicancias: Crítica al concepto de 'Matriz Cultural'. Diálogo Andino 11-12:33-45.

1993 Una experiencia piloto en educación intercultural en la comuna de General Lagos, I Región de Chile. Pueblos Indígenas y Educación 27-28:163-179.
1994 Una experiencia piloto en educación intercultural en la región aymara del norte de Chile. Pueblos Indígenas y Educación 29-30:193-210.

1995 Desarrollo y educación en las comunas de Camarones, General Lagos y Putre. Temas Regionales 2(1):21-33.

1997a Daring to change: The potential of intercultural education in Aymara communities in Chile. Anthropology \& Education Quarterly 28:229-250.

1997b La importancia de la etnomedicina para la atención médica en Arica. Marco conceptual para una medicina intercultural. Actas del Segundo Congreso Chileno de Antropología, Vol. 1, pp. 338-345. Colegio de Antropólogos de Chile, Santiago.

1998 La educación intercultural como proyecto regional. En Investigación Científica y Tecnológica: Visión Histórica, Compromisos y Proyecciones, editado por I. Muñoz, pp.118122. Universidad de Tarapacá, Arica.

Arriaza, P.

1990 Estrategias de Supervivencia Socio-Económica en la Economía Campesina de la Comunidad Aymara de Villablanca, Altiplano Chileno, I Región. Tesis de Licenciatura en Antropología, Escuela de Antropología, Universidad Austral de Chile, Valdivia.

1991 Fuentes Bibliográficas para el Estudio de los Aymaras del Norte de Chile. El Jote Errante, Iquique.

1995 Caracterización de la colonia agrícola de Alto HospicioAlto Molle. Manuscrito en posesión del autor.

2002a Cambio y continuidad en el uso del espacio de los aymaras de Tarapacá. Proyectos de colonización en la Pampa del Tamarugal. Manuscrito en posesión del autor.

2002b Impacto de los proyectos mineros de la provincia de Iquique sobre el patrimonio cultural. El caso de la minera María Inés de Collahuasi. Manuscrito en posesión del autor.

Atria, R.

1970 Sociedad y Valores en la Precordillera de Arica. Corporación de Reforma Agraria, Informe Sociológico, Arica.

Ayala, P., S. Avendaño y U. Cárdenas

2003 Vinculaciones entre una arqueología social y la comunidad indígena de Ollagüe (Región de Antofagasta, Chile). Chungara Revista de Antropología Chilena 35:275-285.

Báez, F.

2002 La etnia atacameña y el agua. Memoria (licenciado en ciencias jurídicas y sociales), Departamento de Ciencias del Derecho, Universidad de Chile, Santiago.

Barriga, V.

1939-1940 Documentos para la Historia de Arequipa. 2 Vol. La Colmena, Arequipa.

1941-1952 Memorias para la Historia de Arequipa. 4 Vol. La Colmena, Arequipa.

Barros, A.

1998 Desarrollo y Pachamama: Paisajes conflictivos en el desierto de Atacama. Estudios Atacameños 13:75-94.

2000 Autonomía y territorio. Actas del XII Congreso Internacional Derecho Consuetudinario y Pluralismo Legal: Desafios en el tercer milenio, compiladas por M. Castro, pp. 548-554. Lom, Santiago.

2004 Crónica de una etnia anunciada: Nuevas perspectivas de investigación a 10 años de vigencia de la Ley Indígena en San Pedro de Atacama. Estudios Atacameños 27:139168. 
Barthel, T.

1959 Ein Frühlingsfest der Atacameños. Zeitschrift für Ethnologie 84-1:25-45.

$1986 \mathrm{El}$ agua y el festival de primavera entre los atacameños. Allpanchis 28:147-184.

Baulieu, A.

1967 El hábitat humano y la economía agrícola en el oasis de Chiu-Chiu. Revista de la Universidad del Norte 4:81-101.

Beltrán, P.

2000 Rituales de la Comunidad de Cariquima. Tesis de Licenciatura en Antropología, Escuela de Antropología, Universidad Academia de Humanismo Cristiano, Santiago.

2002 La representación del espacio y la organización social de la comuna Cariquima. Revista de Historia Indígena 6:131-146.

Beltrán R., P.

2002 Voces Indígenas en el Desierto de Atacama: Acción, Discursos e Identidad. Un Estudio Comparativo del Consejo de Pueblos Atacameños y la Organización Zahli Lickan Ckappur. Tesis de Licenciatura en Antropología, Escuela de Antropología, Universidad Academia de Humanismo Cristiano, Santiago.

Bennett, W.

1946 The Atacameño. En Handbook of South American Indians, editado por J. Steward, Vol. 2, pp. 599-618. Smithsonian Institution Bureau of American Ethnology Bulletin ( $\left.\mathrm{N}^{\circ} 143\right)$. Government Printing Office, Washington.

Berenguer, J.

2004 Caravanas, Interacción y Cambio en el Desierto de Atacama. Sirawi Ediciones, Santiago.

Berenguer, J., V. Castro, F. Plaza y L. Rodríguez

1973 Algunos problemas derivados del análisis de los Censos Generales de Población (1907-1970). Depto. El Loa. Ponencia presentada al I Congreso del Hombre Andino, Arica-Iquique-Antofagasta.

Berenguer, J. y J.L. Martínez

1986 El río Loa, el arte rupestre de Taira y el mito de Yakana. Boletín del Museo Chileno de Arte Precolombino 1:7999.

1989 Camelids in the Andes: Rock art, environment and miths. En Animals Into Art, editado por H. Morphy, pp. 390-416. Unwin \& Hymann, Londres-Boston.

Bermúdez, O.

1973 Pica en el siglo XVIII, estructura económica y social. Revista Chilena de Historia y Geografía 141:7-56

1975 Estudios de Antonio O'Brien sobre Tarapacá. Cartografía y Labores Administrativas 1763-1771. Ediciones Universitarias, Antofagasta.

1980 La población indígena de la doctrina de Pica. Segunda mitad del S. XVIII. Chungara Revista de Antropología Chilena 6:145-215.

1987 El Oasis de Pica y sus Nexos Regionales. Ediciones Universidad de Tarapacá, Arica.

Bernhardson, W.

1982 Natural Resources in an Andean Pastoral Economy: the Aymara of Parinacota, Chile. Master of Art Dissertation in Geography, Department of Geography, University of California, Berkeley.

1985a Tierra, trabajo y ganadería indígena en la economía regional de Arica. Chungara 15:151-167. 1985b El desarrollo de recursos hidrológicos del Altiplano ariqueño y su impacto sobre la economía ganadera de la zona. Chungara 14:169-181.

Bertrand, A.

1879a Noticias de los Departamentos de Tacna, Moquegua $i$ Arequipa: i Algo Sobre la Hoya del Lago Titicaca. Imprenta Nacional, Santiago.

1879b Noticias del Departamento Litoral de Tarapacá i sus Recursos. Imprenta Nacional, Santiago.

1885a Memorias sobre la exploración a las cordilleras del desierto de Atacama. Anuario Hidrográfico de la Marina, Vol. X.

1885b Memoria sobre las Cordilleras del Desierto de Atacama i Rejiones Limítrofes Presentada al Señor Ministro del Interior. Imprenta Nacional, Santiago.

Bittmann, B.

1979 Cobija y Alrededores en la Época Colonial (1600-1750). Actas del VII Congreso de Arqueología de Chile: Altos de Vilches, 27 de octubre al $1^{\circ}$ de noviembre de 1977, Vol. 2, pp. 327-356. Ediciones Kultrun, Santiago.

1983 Cobija, Panorama etnohistórico en relación a los informes del Dr. José Agustín de Arze, 1786-1787. Chungara 10:147-153.

1984 El Programa Cobija: Investigaciones antropológicomultidisciplinarias en la Costa Centro Sur Andina: Notas etnohistóricas. En Contribuciones a los Estudios de los Andes Centrales, editado por S. Masuda, pp. 101-149. Universidad de Tokio, Tokio.

1988 Recursos y supervivencia en el desierto de Atacama. En Recursos Naturales Andinos, editado por S. Masuda, pp. 153-208. Universidad de Tokio, Tokio.

Bittmann, B., coordinadora

1982 Simposio: Culturas atacameñas desarrollado en Manchester, Inglaterra, $44^{\circ}$ Congreso Internacional de Americanistas. Universidad del Norte, Antofagasta.

Bittmann, B., G. Le Paige y L. Núñez

1978 Cultura Atacameña. Ministerio de Educación, Departamento de Extensión Cultural, Santiago.

Bollaert, W.

1975 [1860] Descripción de la provincia de Tarapacá. Norte Grande I (3-4).

1981 [1851-1854-1860] Noticias antropológicas de la costa del Norte Grande del desierto de Atacama y de la provincia de Tarapacá, Chile. Introducción de B. Bittmann, traducción de J. Carmona y notas de R. Mavrakis. Antofagasta, Universidad del Norte.

Boman, E.

1908 Antiquités de la Région Andine de la République Argentine et du Désert d'Atacama. 2 Vols. Impremerie Nationale, París.

Bourdieu, P.

1999 ¿Qué Significa Hablar? Akal, Madrid.

2001 Langage et Pouvoir Symbolique. Fayard, Francia.

Bowman, I.

1942 [1924] Los senderos del Desierto de Atacama. Traducido por E. Romero. Sociedad Chilena de Historia y Geografía, Santiago.

Bravo, A.

2003 Arqueología aplicada al desarrollo de comunidades atacameñas. Chungara Revista de Antropología Chilena 35:287-293. 
Briones, L., J. Andrade, J. Chacama y G. Espinosa

1989 Proyecto Catastro, evaluación y estudio de la pintura mural en el área centro sur andina. Primer informe técnico de avance año 1988 (proyecto UTA-OEA). Departamento de Arqueología, Universidad de Tarapacá, Arica.

Briones, L. y P. Vilaseca 1983 Pintura Religiosa en Tarapacá. Fe y Color en el Desierto. Cabo de Hornos, Santiago.

Briones, V.

1999 Agua, territorio y malostratos: los espacios de conflictos entre ayllu y principales, Tacna Siglo XVIII. Chungara Revista de Antropología Chilena 31:293-305.

Bustos, A.

1999 Etnografía Atacameña. Universidad de Antofagasta, Instituto de Investigaciones Antropológicas, Antofagasta.

2000 Patrimonio Cultural Atacameño y Turismo. Universidad de Antofagasta, Instituto de Investigaciones Antropológicas, Antofagasta.

Bustos, A. y R. Lehnert

1999 Arte Rupestre Atacameño. Universidad de Antofagasta, Instituto de Investigaciones Antropológicas, Antofagasta.

2000 Historia del Pueblo Atacameño. Universidad de Antofagasta, Fundación Minera Escondida, Municipalidad de San Pedro de Atacama, Antofagasta.

Cajías, F.

1977 La Provincia de Atacama (1825-1842). Instituto Boliviano de Cultura, La Paz.

Cárdenas, U.

1998 Entre el tolar y el pajonal: Percepción ambiental y uso de plantas en la comunidad atacameña de Talabre, II Región, Chile. Estudios Atacameños 16:251-282.

Carrasco, A.M.

1993a Mujeres y participación social en la sociedad aymara contemporánea. En Huellas, Seminario Mujer y Antropología, Problematización y Perspectivas, editado por S. Montecino y M.E. Boisier, pp.175-183. CEDEM, Santiago.

1993b Antecedentes para un diagnóstico de la situación de la mujer en el sector rural de la I Región de Tarapacá. Taller de Estudios Andinos, Documentos de Trabajo, Arica.

1994a Mujer aymara y trabajo remunerado. Temas Regionales 1(1):30-41.

1994b Tintes naturales. Recuperación de una milenaria tradición relegada al olvido. FONDART, Taller de Estudios Andinos, Arica.

1997 Mujer rural y participación social en la I Región de Tarapacá. Taller de Estudios Andinos, Documentos de Trabajo, Arica.

1998a Mujeres aymara e inserción laboral. Revista de Ciencias Sociales 8:3-96 (Universidad Arturo Prat).

1998b Constitución de género y ciclo vital entre los aymaras contemporáneos del Norte de Chile. Chungara Revista de Antropología Chilena 30:87-103.

1999 Familia aymara e inserción urbana. Taller de Estudios Andinos, Documentos de Trabajo, Arica.

2001 Violencia conyugal entre los aymaras del altiplano chileno: Antecedentes para comprender las relaciones de género en el matrimonio. Revista de Ciencias Sociales 3:85-96 (Universidad José Santos Ossa).

2003a Diferencias de género en las ideas y en las prácticas a través del curso de la vida entre los aymaras del norte de Chile. Taller de Estudios Andinos, Documentos de Trabajo, Arica. 2003b Llegando al mundo terrenal: embarazo y nacimiento entre los aymaras del norte de Chile. En Mujeres, Espejos y Fragmentos. Antropología de Género y Salud en el Chile del Siglo XXI, editado por S. Montecino, R. Castro y M.A. de la Parra, pp. 84-97. Antártica, Santiago.

2005a Influencias de la ideología religiosa en las significaciones de la sexualidad en mujeres aymaras del norte de Chile. Manuscrito en posesión del autor.

2005b Significaciones de la sexualidad en hombres y mujeres aymará del Norte de Chile. Manuscrito en posesión del autor.

2005c Diversidad en la norma: diferencias en las significaciones de la sexualidad femenina en el norte de Chile. Manuscrito en posesión del autor.

Carrasco, C., C. Agüero, P. Ayala, M. Uribe y B. Cases

2003 Investigaciones en Quillagua: Difusión del conocimiento arqueológico y protección del patrimonio cultural. Chungara Revista de Antropología Chilena 35:321-326.

Carrasco, A.M. y B. Cofré

2001 Antecedentes para comprender la construcción cultural de la sexualidad entre los aymaras contemporáneos del norte de Chile. Documentos de Trabajo, Taller de Estudios Andinos, Arica.

Carrasco, A.M. y B. Cofré, editoras.

2003 Conociendo la Historia y Cultura de Nuestra Región. Andros Impresores, Santiago.

Carrasco, A.M. y V. Gavilán

2000 Incidencia del sistema educacional en la división del trabajo de mujeres y hombres, entre los aymaras del Norte de Chile. Documentos de Trabajo, Taller de Estudios Andinos, Arica.

2004 Los contextos éticos y morales de la sexualidad aymara y no aymara en el norte de chileno. Documentos de Trabajo, Taller de Estudios Andinos, Arica.

2006 Sexualidad y género: la unidad de lo femenino y lo masculino como símbolos de reproducción y fertilidad entre los Aymará del norte de Chile. En Espacios de género. Imaginarios, Identidades e Historia, coordinado por L. Rebolledo y P. Tomic, pp. 169-186. Universidad Autónoma de Baja California, Mexicali.

2007 Representaciones aymara del cuerpo, sexo y género: Una aproximación a las diferencias sexuales. Manuscrito en posesión de los autores.

2009 Representaciones del cuerpo, sexo y género entre los aymaras del norte de Chile. Chungara Revista de Antropología Chilena 41:83-100.

Carrasco, A.M., V. Gavilán y H. González

1993 Una Experiencia Productiva con Mujeres Aymara: Promoción a la Producción Artesanal. Documentos Técnicos $\mathrm{N}^{\circ}$ 4, Taller de Estudios Andinos, Arica.

Carrasco, A.M., V. Gavilán, H. González y H. Gundermann

1993 La experiencia del Taller de Estudinos Andinos (TEA) en la promoción de la producción artesanal. Proposiciones 23:397-424.

Casassas, J.M.

1967 El 'libro de varias hojas-1611-1698' de la antigua parroquia de Chiu-Chiu. Revista de la Universidad del Norte 2:27-30.

1974a Fuentes Documentales para el Estudio Etno-histórico de las Poblaciones Indígenas del Norte Grande Chileno y Tierras Adyacentes. Universidad del Norte Antofagasta. 
1974b La Región Atacameña en el Siglo XVII: Datos Históricos Socioeconómicos sobre una Comarca de América Meridional. Universidad del Norte, Antofagasta.

1974c Iglesias y Capillas en la Región Atacameña: Administraciones Españolas y Bolivianas. Universidad del Norte, Antofagasta.

1974d Relación de los sacerdotes que ejercieron ministerio en la región atacameña durante el siglo XVIII y algunos documentos relativos a su misión. Norte Grande I (1):4554.

1974e Algunas noticias sobre los partidos de Arica y Tarapacá hacia fines del siglo XVIII y principios del XIX. Norte Grande I (2):217-226.

1974f Noticias demográficas sobre la región atacameña durante el siglo XVIII. Estudios Atacameños 2:75-92.

Castro, L.

1999 Cuando el Susurro del Agua se Acalló en el Desierto: La Expropiación de las Aguas del Valle de Quisma, el Abastecimiento Fiscal a Iquique y el Debate sobre el Problema del Desarrollo Económico Regional. Tarapacá 1912-1937. Tesis para optar al grado de Magíster en Historia, Universidad de Santiago de Chile, Santiago.

2004 Recursos hídricos altoandinos, estrategias de desarrollo económico y proyectos de riego: Tarapacá, 1880-1930. Chungara Revista de Antropología Chilena 36:205-220.

Castro, L. y C. Figueroa

2001-2002 Proyectos de irrigación de los valles de Tacna, Lluta y Azapa: documentos inéditos del archivo de la sucesión Fernández Errázuriz, 1902-1903. Diálogo Andino 20-21: 81-113.

2005 Documentos para la Historia Regional: Padroncillos y Talonarios de Predios Rústicos de Tarapacá 1864-1878. Universidad de Valparaíso-Universidad Santo Tomás, Viña del Mar.

Castro, M.

1982 Estrategias socioculturales de subsistencia en las comunidades altoandinas en el interior de la provincia de Arica. En El Hombre y los Ecosistemas de Montaña, editado por A. Veloso y E. Bustos, Vol. 2, pp. 99-132. Programa MAB-6, UNESCO, Montevideo.

1996 El manejo del agua en regiones aymaras y atacameñas en Chile: organización, conflictos y legislación. En La integración Surandina Cinco Siglos Después, compilado por X. Albó, M. I. Arratia, J. Hidalgo, L. Núñez, A. Llagostera, I. Remy y B. Revesz, pp. 431-446. Centro de Estudios Regionales Andinos Bartolomé de Las Casas, Cusco.

1997 Agua, derechos y cultura en los Andes del Norte de Chile. Un enfoque desde la antropología jurídica. Chungara 29:63-80.

2000 Llameros de puna salada en los Andes del norte de Chile. En Pastoreo Altoandino. Realidad, Sacralidad y Posibilidades, editado por J. Flores Ochoa y Y. Kobayashi, pp. 85-109. Plural/MUSEF, La Paz.

2001a El agua en el derecho consuetudinario de aymarás y atacameños del norte de Chile. Revista de Derecho Administrativo Económico de Recursos Naturales 3 (2):345353.

2001b Normas locales y competencia sobre el agua en las comunidades aymarás y atacameños del norte de Chile. En Derechos de Agua y Acción Colectiva, editado por R. Boelens y P. Hoogendam, pp. 240-60. Instituto de Estudios Peruanos, Lima.
Castro, M. y M. Bahamondes

1987 Cambios en la tenencia de la tierra en un pueblo de la precordillera del Norte de Chile: Socoroma. Revista Chilena de Antropología 6:35-57.

1988 Control de la tierra en la cabecera del valle de Lluta. Revista Chilena de Antropología 7:99-113.

1997 Pastoreo en humedales de tierras altas en los Andes del norte de Chile: persistencia y cambios. Actas del Segundo Congreso Chileno de Antropología, Vol. 2, pp. 559-566. Colegio de Antropólogos de Chile, Santiago.

Castro, M., M. Bahamondes, M. Jaime y C. Meneses

1992 Cultura Hídrica: Un Caso en Chile. ORCAL, La Habana.

Castro, M., M. Bahamondes, M. Jaime, C. Meneses y C. Navarrete

1991 Cultura, tecnología y uso del agua en un pueblo andino del norte de Chile. Revista Chilena de Antropología 10:4560.

Castro, M., C. Villagrán y M. Kalin

1981 Estudio etnobotánico en la precordillera y altiplano de los Andes del norte de Chile. En El Hombre y los Ecosistemas de Montaña, editado por A. Veloso y E. Bustos, Vol. 2, pp.133-203. Programa MAB-6, UNESCO, Montevideo.

Castro, N. y J. Hidalgo

1999 Brujos y brujería en la Atacama colonial. Inorganicidad de una representación ideológica y diseminación de una matriz cultural (Introducción y transcripción del 'Quadernos sobre barios delitos y supersticiones' del corregidor Manuel Fernández Valdivieso, Atacama s. XVIII). Estudios Atacameños 17:91-124.

2002 Fiestas, borracheras y rebeliones (Introducción y transcripción del expediente de averiguación del tumulto acaecido en Ingaguasi, 1777). Estudios Atacameños 23:77-109.

Castro, V.

1986 An approach to the Andean Etnozoology: Toconce. Cultural attitudes to animals including birds, fish, and invertebrates. The World Archaeological Congress, 1-7 September 1986, Vol. 2, Sección B: 1-18. Allen \& Unwin, Londres.

1987 Diagnóstico agrícola Provincia de El Loa: estudios antropológicos, Informes I, II y III. Consultores Ecológicos y Ambientales, Santiago.

1988 Entrevista a un yatiri de la localidad de Toconce, II Región, Chile (Agosto 1979). En Plantas Medicinales de Uso Común en Chile, editado por C. Farga, J. Lastra y A. Hoffman, Vol. 3, pp.117-119. PAESMI, Santiago.

1991 Un proceso de extirpación de idolatrías en Atacama, siglo XVII. Historia y Cultura XX:131-150.

1993 Un proceso de extirpación de idolatrías en Atacama, siglo XVII. En Catolicismo y Extirpación de Idolatrías: Siglos XVI-XVIII, Charcas, Chile, México y Perú, editado por G. Ramos y H. Urbano, pp. 347-366. Centro de Estudios Regionales Andinos Bartolomé de Las Casas, Cusco.

1997 Huacca Muchay: Evangelización y Religión Andina en Charcas, Atacama la Baja. Tesis para optar al grado de Magíster en Historia, Mención Etnohistoria, Escuela de Postgrado, Facultad de Filosofía y Humanidades, Universidad de Chile, Santiago.

1998 La dinámica de las identidades en la subregión de río Salado, Provincia El Loa, II Región. Actas del I Encuentro Nacional Interinstitucional de Investigadores de Identidades Culturales. Programa de Desarrollo de Identidades Culturales, 
editadas por M. Dannemann, pp. 5-50. Universidad de Chile, Departamento de Investigación y Desarrollo, Santiago.

2001 Atacama en el tiempo, territorios, identidades, lenguas (Provincia El Loa, II Región). Anales de la Universidad de Chile, VI Serie, 13, agosto 2001. [http://www2.anales. uchile.cl/an.completa/0,1281,SCID\%253D120\%2526ISID \%253D9\%62626ACT\%253D0\%2526PRT\%253D118\%,0 0.html]

Castro, V. y C. Aldunate

2003 Sacred Mountain in the Highlands of the South Central Andes. Journal of Mountain Research and Development 23:73-79.

Castro, V., C. Aldunate y J. Berenguer

1980 Sacralidad de Toconce ayer y hoy. Ponencia presentada en el VIII Congreso de Arqueología Chilena, Valdivia.

Castro, V., C. Aldunate y V. Varela

2004 Ocupación humana del paisaje desértico de Atacama, Región de Antofagasta. ARQ 57:14-17.

Castro, V. y F. Gallardo

1995-1996 El poder de los gentiles. Arte rupestre en el río Salado (Desierto de Atacama). Revista Chilena de Antropología 13:79-98.

Castro, V. y J.L. Martínez

1996 Poblaciones indígenas de Atacama. En Etnografía. Sociedades Indígenas Contemporáneas y su Ideología, editado por J. Hidalgo, V. Schiappacasse, H. Niemeyer, C. Aldunate y P. Mege, pp. 69-109. Andrés Bello, Santiago.

Castro V. y V. Varela

1992 Así sabían contar. Oralidad 4:16-27.

2000 Los caminos del 'reinka' en la región del Loa Superior. Desde de etnografía a la arqueología. Actas del XIV Congreso Nacional de Arqueología Chilena, Vol. 1, pp. 815-840. Sociedad Chilena de Arqueología y Museo Regional de Atacama, Copiapó.

Castro, V. y V. Varela, editoras

1994 Ceremonias de Tierra y Agua. Ritos Milenarios Andinos. FONDART, Ministerio de Educación y Fundación Andes, Santiago.

Castro, V. y C. Villagrán

2004 Ciencia Indígena de los Andes del Norte de Chile. Editorial Universitaria, Santiago.

Cereceda, V.

1977 Las talegas de Isluga: Apuntes para una semiología del textil andino. Centro Isluga, Iquique.

1978 Sémiologie des tissus andins: les talegas d'Isluga. Annales. Économies, Sociétés, Civilisations 33 (5-6):1017-1036.

1986 The semiology of Andean textils: The talegas of Isluga. Anthropological history of Andean polities, editado por J. Murra, N. Wachtel y J. Revel, pp. 149-173. Cambridge University Press y Editions de la Maison des Sciences de l'Homme, New York-París.

1988 Aproximación a una estética aymara-andina: de la belleza al Tinku. En Raíces de América: el Mundo Aymara, editado por X. Albó, pp. 283-364. Alianza, Madrid.

1990 A partir de los colores de un pájaro. Boletín del Museo Chileno de Arte Precolombino 4:57-109.

Chacama, J., L. Briones y G. Espinosa

1988-1989 El arte mural en las iglesias coloniales de la primera región y la tradición pictórica andina. Diálogo Andino 7-8:101-120.
Chacama, J., G. Espinosa y P. Arévalo

1992 Arquitectura religiosa en la sierra y puna de la Primera Región de Chile. Documento de Trabajo $\mathrm{N}^{\circ}$ 6, Departamento de Arqueología y Museología, Universidad de Tarapacá, Arica.

Chamorro, A. y C. Tocornal

2004 Prácticas de salud en las comunidades del Salar de Atacama: aportes a una mirada intercultural. Manuscrito en posesión de los autores.

2005 Prácticas de salud en las comunidades del Salar de Atacama: hacia una etnografía médica contemporánea. Estudios Atacameños 30:17-134.

Checura, J.

1965 Mamiña y sus leyendas. Noticiario Mensual. Museo Nacional de Historia Natural X-113:2-13.

1967 Ritmos Regionales. Música y Canciones Tradicionales en los Departamentos de Iquique y Pisagua. Museo Regional de Iquique, Iquique.

1968 Análisis Sociológico de Pueblos Tipo en los Departamentos Iquique y Pisagua de la Provincia de Tarapacá. Universidad del Norte, Museo Regional de Iquique, Iquique.

1976 Observaciones sobre el hombre andino en el norte de Chile. En Homenaje al Dr. Gustavo Le Paige s.j., pp. 245254. Universidad del Norte, Antofagasta.

Chipana, C.

1986 La identidad étnica de los aymarás en Arica. Chungara 16-17:251-261.

1989 La inadecuada exportación de camélidos en Chile atenta a la cultura y la visión india de los Aymara. En La visión india: tierra, cultura, lengua y derechos humanos. Ponencias de un simposio que se llevó a cabo en el marco del 460 Congreso Internacional de Americanistas, Ámsterdam, Holanda, julio 1988, pp. 99-123. Musiro, Fundación para la Cultura de los Indígenas de las Américas, Leiden.

1995 Propuesta de la provincia de Parinacota y comuna de Camarones. Pentukun 2:89-95.

1996a Hacia un pachakuti. En La Integración Surandina Cinco Siglos Después, compilado por X. Albó, M.I. Arratia, J. Hidalgo, L. Núñez, A. Llagostera, I. Remy y B. Revesz, pp. 447-454. Centro de Estudios Regionales Andinos Bartolomé de las Casas, Cusco.

1996b La universidad y los pueblos indígenas: mito y realidad. En Universidad y Pueblos Indígenas, compilado por R. Morales, pp. 79-86. Instituto de Estudios Indígenas, Universidad de la Frontera, Temuco.

2000 Percepción andina de la educación, desde un punto de vista aymara. En Educación y Pueblo Aymara, S. González, F. Mena, C. Chipana, C. González, H. Alegría y P. García, pp. 68-96. Universidad Arturo Prat, Instituto de Estudios Andinos Isluga, Iquique.

Clairis, Ch.

1976 Esquisse phonologique de l'aymará parlé au Chili. La Linguistique 12 (2):143-152.

CONSECOL Consultores

1988 Diagnóstico Agrícola de la Provincia de El Loa. 4 Vols. Secretaría Regional de Planificación y Coordinación II Región, Antofagasta.

Contardo, M. y V. Espinosa

1991 Atlas lingüístico de la provincia de Parinacota (A.L.P.A). Revista de Lingüística Teórica y Aplicada 29:41-45. 
Contreras, E.

1994 Cultura y naturaleza en la cuenca del Salar de Atacama. Reflexión preliminar. Estudios Atacameños 11:179-184.

2005 Pueblos Transfronterizos en la Puna de Atacama: Conectividad de Redes en el País más allá de las Nubes. Tesis para optar al título de Antropólogo Social, Departamento de Antropología, Universidad de Chile, Santiago.

Cuadra, $\mathrm{M}$.

1999 Los derechos de agua de propiedad ancestral de las comunidades atacameñas del norte de Chile. Revista de Derecho Administrativo Económico 2 (1):85-94.

2000 Teoría y práctica de los derechos ancestrales de agua de las comunidades atacameñas. Estudios Atacameños 19:93-112.

2001 La protección de las zonas de vegas y bofedales del norte de Chile: una perspectiva indígena. Revista de Derecho Administrativo Económico de Recursos Naturales 3 (2):355362.

Cúneo Vidal, R.

1977a Obras Completas. Vol. 1: Historia de la civilización peruana. Historia de los Cacicazgos Hereditarios del Sur del Perú. Gráfica Morsom, Lima.

1977b Obras Completas. Vol. 4: Precursores y Mártires de la Independencia del Perú. Gráfica Morsom Lima.

1977c Obras Completas. Vol. 5: Historia de la Fundación de la Ciudad de San Marcos de Arica. Historias y Leyendas de Arica, Tarapacá y Atacama. Gráfica Morsom, Lima.

1977d Obras Completas. Vol. 6: Diccionario HistóricoBiográfico del Sur del Perú. Gráfica Morsom, Lima.

Dagnino, V.

1909 El Correjimiento de Arica. 1535-1784. Imprenta La Época, Arica.

1910 El Ayuntamiento de Tacna: Tributo a la Patria en su Centenario. Taller tipográfico de Carlos García Dávila, Tacna.

Dannemann, M. y A. Valencia

1989 Grupos aborígenes chilenos: su situación actual y distribución territorial. Instituto de Investigaciones del Patrimonio Territorial de Chile, Universidad de Santiago de Chile, Santiago.

Délano, $\mathrm{P}$.

1982 Aspectos Socioeconómicos de una Comunidad del Norte Grande: Caspana. Tesis de Licenciatura en Antropología, Departamento de Ciencias Sociológicas y Antropológicas, Universidad de Chile, Santiago.

Díaz, A.

1997 "Sigue la cumbia". Percepción de la cumbia andina en la ciudad de Arica: un ejercicio. Revista Percepción 1:2438.

Díaz, A., I. Fernández y O.P. Hurtado

2002 Sotoca, Historia Viva. Rescate de la Memoria Histórica de la Comunidad de Sotoca, Comuna de Huara, Región de Tarapacá. FODART, Ministerio de Educación, Iquique.

Díaz, E. 1990 Notas sobre el aymara de la provincia de Iquique. Camanchaca 11:29-33.

Dougnac, F. 1975 La legislación aplicable a los indígenas del norte de Chile. Norte Grande I (3-4):437-444.

Dransart, $\mathrm{P}$.

1988 Continuidad y cambio en la producción textil tradicional aymara. Hombre y Desierto 2:41-57.
1991 Fibre to fabric: The role of fabric in camelid economies in prehispanic and contemporary Chile. Doctoral Dissertation, University of Oxford, Oxford.

1995 Inner worlds and the event of a thread in Isluga, northern Chile. En Andean Art: Visual Expression and its Relation to Andean Beliefs and Values, editado por P. Dransart, pp. 228-242. Avebury (Worldwide Archaeology Series), Aldershot, Hampshire.

1996 Las flores de los rebaños en Isluga: la vida cultural de los ganaderos y camélidos en el norte de Chile. Nuevo Texto Crítico 18:29-39.

1997 Cultural transpositions: writing about rites in the llama corral. En Creating Context in Andean Cultures, editado por R. Howard-Malverde, pp. 85-98. Oxford University Press, New York, Oxford.

2002a Concepts of spiritual nourishment in the Andes and Europe: Rosaries in cross-cultural contexts. Journal of the Royal Anthropological Institute 8 (1):1-21.

2002b Coloured knowledges: Vision and the dissemination of knowledge in Isluga, Northern Chile. En Knowledge and Learning in the Andes: Ethnographic Perspectives, editado por H. Stobart y R. Howard, pp. 56-78. Liverpool University Press, Liverpool.

Dueñas, S.

2003 La privatización de las tierras de reparto indígenas: indios, Estado e intereses locales. Tacna, 1828-1841. En Tarapacá un Desierto de Historias. Historia, Cultura y Memoria en el Norte Chileno Siglos XIX y XX, compilado por M. Gálvez, R. Ruz y A. Díaz, pp. 9-20. Oñate Impresores, Iquique.

2005 Efectos del Liberalismo Decimonónico en la Sociedad, Población y Bienes Agrícolas Indígenas: la Comunidad de Tacna entre 1826 y 1864. Tesis para optar al grado de Magíster en Historia, Mención Etnohistoria, Escuela de Postgrado, Facultad de Filosofía y Humanidades, Universidad de Chile, Santiago.

Durston, A. y J. Hidalgo

1999 La presencia andina en los valles de Arica, siglos XVI-XVIII: casos de regeneración colonial de estructuras archipielágicas. Chungara 29:249-273.

Echeverría, C.

1998a De Hombre a Persona, de Mujer a Esposa: Una Aproximación Desde el Matrimonio a las Relaciones de Género Entre las Mujeres y Hombres Aymaras Casados, de Isluga y Cariquima. Tesis de Licenciatura en Sociología, Departamento de Ciencias Sociales, Universidad Arturo Prat, Iquique.

1998b División sexual del trabajo y matrimonio aymara contemporáneo desde una perspectiva de género. Revista de Ciencias Sociales 8:97-108.

1999 Estado y educación rural en el norte de Chile. Documentos de Trabajo, Taller de Estudios Andinos, Arica.

Egaña, F.

2005 Procesos de Legitimación de Especialistas Médicos Tradicionales en Contextos Urbanos: los Casos de un Yatiri y un Qulliri aymaras de la Ciudad de Arica. Tesis de Licenciatura en Antropología, Escuela de Antropología, Universidad Austral de Chile, Valdivia.

Escalante, $\mathrm{M}$.

1999 La mesa de Todos Santos en San Pedro de Atacama, Chile. En Los Vivos y los Muertos; Duelo y Ritual Mortuorio en los Andes, editado por J. van Kessel, pp. 39-43. IECTA, Iquique. 
2001 La mesa de Todos Santos en San Pedro de Atacama, Chile. Chungara Revista de Antropología Chilena 33:245248.

Espinosa, V.

1996 El español hablado en la provincia de Parinacota.

Estudios Filológicos 31:191-202.

1999 Análisis crítico de un discurso en la variedad del español andino. Estudios Filológicos 34:121-130.

Fernández C., E.

2001 Un diseño curricular alternativo para las comunidades aymaras del norte de Chile. Revista Pensamiento Educativo 29:277-295.

Figueroa, C.

2001 Riego y Sociedad: Pica Siglo XVIII. Tesis para optar al título de Profesor de Historia, Instituto de Estudios Humanísticos, Universidad de Valparaíso, Valparaíso.

Folla, J.C.

1989 Anthropologie Économique d'une Communauté Paysanne du Désert d'Atacama: Socaire. Tesis para optar al grado de Magíster en Ciencias Antropológicas, Faculté des Études Supérieures, Université de Montreal, Montreal.

Gaete, A.

1975 Análisis estadístico del despoblamiento verificado entre los años 1862-1970, según diversos estratos de altura, en las hoyas hidrográficas de las quebradas de Aroma y Tarapacá. Norte Grande I (3-4):447-455.

Galdames, L.

1987 Vitalidad de la piedra y petrificación de la vida: Notas sobre mentalidad andina. Diálogo Andino 6:127-143.

1990 Apacheta: La ofrenda de piedra. Diálogo Andino 9:9-25.

1999 El ámbito de 'lo local' como perspectiva de análisis de los pueblos andinos del norte de Chile. Diálogo Andino 18:9-19.

2009 Rómulo Cúneo-Vidal. Pionero de la etnohistoria andina. Chungara Revista de Antropología Chilena 41:45-50.

Galdames, L., L. Álvarez, S. Chacón, P. Dauelsberg y W. Ríos 1981 Historia de Arica. I. Municipalidad de Arica, Arica.

Gálvez, M. y R. Ruz

2004 Parinacota: Historia y Cultura Andina. CORDAP, Gobernación de Parinacota, Arica.

García, B.

1997 El Discurso Político de las Organizaciones Aymaras en el Norte de Chile. Tesis Doctoral, Facultad de Geografía e Historia, Universidad Complutense de Madrid, Madrid.

García, P.

2002 Aru pirwa. Breve Diccionario Aymara-Castellano/ Castellano-Aymara. Universidad Arturo Prat, Instituto de Estudios Andinos Isluga, Iquique.

Gavilán, V.

1985a Mujer aymara y producción textil. El altiplano de Tarapacá. CEM-PEMCI, Serie Mujer y Producción $\mathrm{N}^{\circ} 2$, Santiago.

1985 b Historias de vida de mujeres aymaras. Centro de Estudios de la Mujer, Serie Las Mujeres Hablan N ${ }^{\circ} 3$, Santiago.

1988 La mujer aymara y la migración altiplano-valle/ciudad. Resultados de Investigación, Taller de Estudios Andinos, Arica.

1993 Relaciones de género en la cultura aymara: Complementariedad y subordinación. En Huellas, Seminario Mujer y Antropología, editado por S. Montecino y M.E. Boisier, pp. 83-95. CEDEM, Santiago.
1995 Una aproximación a las relaciones de género entre los aymara del norte de Chile. Temas Regionales 3:42-59.

1996 Mujeres y Hombres en Isluga y Cariquima: Una Aproximación a las Relaciones de Género Entre los Aymaras del Norte de Chile. Tesis para optar al grado de Magíster en Antropología, FLACSO, Quito.

1997 Participación social y política de la mujer campesina e indígena. En Hacia una Pedagogía de Género. Ponencias y Documentos/Seminario Latinoamericano sobre Experiencias en Educación no formal con mujeres realizado en Melgar, Colombia, del 28 de Octubre al 1 de Noviembre de 1996, editado por T. Büttner, I. Jung y L. King, pp. 213-221. DSEUNESCO, Bonn.

1998 Elaboraciones de género en la religiosidad de mujeres y hombres aymara del norte de Chile. Revista de Ciencias Sociales 8:65-82.

1999 Las representaciones de lo femenino y lo masculino y sus vinculaciones con las prácticas sociales de mujeres y hombres aymara del norte de Chile. Documentos de Trabajo, Taller de Estudios Andinos, Arica.

2001 Los rituales propiciatorios de la vida: un ensayo de comprensión de las formas simbólicas del género en las comunidades aymaras del norte de Chile. Documentos de Trabajo, Taller de Estudios Andinos, Arica.

2002 'Buscando vida': Hacia una teoría aymara de la división del trabajo por género. Chungara Revista de Antropología Chilena 34:101-117.

2003 Festividades andinas en el norte chileno. Documentos de Trabajo, Taller de Estudios Andinos, Arica.

Gavilán, V. y A.M. Carrasco

2009 Festividades andinas y religiosidad en el norte chileno. Chungara Revista de Antropología Chilena 41:101-112.

Gavilán, V. y L. Ulloa

1993 Textilería aymara. En Memoria y Cultura. Femenino y Masculino en los Oficios Artesanales, editado por X. Valdés, L. Rebolledo, V. Gavilán, L. Ulloa, A. Willson, pp. 75-89. CEDEM-FONDEC, Santiago.

Giménez, G.

1987 La problemática de la cultura en las ciencias sociales. En La teoría y el Análisis de la Cultura, editado por G. Giménez, pp. 15-72. SEP, Universidad de Guadalajara, COMECSO, Guadalajara.

Gómez, C.

1980 La Comunidad Campesina Indígena del Loa Superior. Tesis de Licenciatura en Antropología, Departamento de Ciencias Sociológicas y Antropológicas, Universidad de Chile, Santiago.

Gómez, D.

1976 Narraciones tradicionales de Socaire. Cuadernos de Filología 5: 47-68.

1979 Siete relatos populares peineños. Cuadernos de Filología 10:37-44.

1980 Veinticuatro relatos populares toconceños. Cuadernos de Filología 12:80-108.

1981-1982 Los pueblos andinos de la Segunda Región y su alimentación tradicional. Cuadernos de Filología 15-16:4980.

1982 Narrativa popular atacameña; Habitat. Cultura. Corpus. Cuadernos de Filología 17:1-110.

1993 Así Hablan las Montañas (Caurcota Icks Yoconama): Leyendas Andinas de la Segunda Región. Universidad de Antofagasta, Instituto de Investigaciones Antropológicas, Antofagasta. 
1995 Cultura y Educación Atacameñas. Universidad de Antofagasta, Instituto de Investigaciones Antropológicas, Antofagasta.

Gómez, D., compilador

1994 Cuentos de Nuestra Tierra (Coricota Kunza Lickana). Universidad de Antofagasta, Instituto de Investigaciones Antropológicas, Antofagasta.

Gómez, D., J. Ahumada y E. Necul

1998 Medicina Tradicional Atacameña. FONDART, Antofagasta.

Gómez, D. y A. Bustos

1999 Educación Intercultural Atacameña. Universidad de Antofagasta, Instituto de Investigaciones Antropológicas, Antofagasta.

Gómez, D. y E. Siarez

1995 Alimentación Tradicional Atacameña. Norprint, Antofagasta.

González, H.

1988 Acerca del rol y la importancia de la artesanía textil en la economía campesina andina (Isluga-Cariquima). Resultados de Investigación, Taller de Estudios Andinos, Arica.

1990 Timar. Diagnóstico socioeconómico. Acerca de la utilización de dos espacios económicos: el campo y la ciudad. Serie Documentos de Trabajo, Taller de Estudios Andinos, Arica.

1991 Desarrollo organizativo y participación política reciente entre los Aymara del Norte de Chile. Documentos de Trabajo, Taller de Estudios Andinos, Arica

1994 Disponibilidad, acceso y sistemas de tenencia de la tierra entre los Aymara del Altiplano de la I Región de Tarapacá. En Tierra, Territorio y Desarrollo Indígena, pp. 67-77. Universidad de la Frontera, Instituto de Estudios Indígenas, Temuco.

1996a Características de la migración campo-ciudad entre los aymaras del norte de Chile. Corporación Norte Grande, Documentos de Trabajo, Arica.

1996b Los migrantes aymaras en la ciudad: acceso a educación, vivienda y salud. Documentos de Trabajo, Corporación Norte Grande, Arica.

1997a La inserción económica de los migrantes aymara en la ciudad: el trabajo como empresa familiar y la reproducción cultural. Actas Segundo Congreso Chileno de Antropología, Vol. I, pp. 315-324. Colegio de Antropólogos de Chile, Santiago.

1997b Economía y uso del espacio en la sociedad aymara actual. Actas Segundo Congreso Chileno de Antropología, Vol. 2, pp. 567-579. Colegio de Antropólogos de Chile, Santiago. 1998a Disponibilidad, acceso y sistemas de tenencia de la tierra entre los Aymara del altiplano de la I Región de Tarapacá. En El Altiplano. Ciencia y Conciencia en los Andes, pp. 277283. Universidad de Chile, Santiago.

1998b Apuntes sobre el tema de la identidad cultural en la región de Tarapacá, Estudios Atacameños 13:27-45.

1999 El valle de Azapa: línea base social, económica y cultural. Documentos de Trabajo, serie Medio Ambiente y Desarrollo, Taller de Estudios Andinos, Arica.

2000a Identidad cultural aymara, nacionalidad y globalización. En ¿Hay Patria que Defender? La Identidad Nacional frente a la Globalización, varios autores, pp. 263-275. CED, Ediciones del Segundo Centenario Santiago. 2000b El tema de la identidad cultural en la Región de Tarapacá. En Investigación Universitaria hacia el Siglo XXI. Propuestas y Desafíos desde las Regiones, editado por I. Muñoz, pp. 127-145. Universidad de Tarapacá, Arica.

2001a Toconce: la transformación de un sistema agro-ganadero. Estudios Atacameños 17:45-59.

2001b Los aymaras contemporáneos, siglos XX y XXI. En Pueblos del Desierto. Entre el Pacífico y los Andes, varios autores, pp. 110-115. Universidad de Tarapacá, Santiago. 2002a Las comunidades y sectores aymaras de los valles y oasis de la Región de Tarapacá. Aspectos económicos, demográficos y socio-culturales. Corporación Taller de Estudios Andinos, Arica.

2002b Los aymaras de la Región de Tarapacá y el período republicano temprano (1821-1879). Comisión Verdad Histórica y Nuevo Trato, Documento de Trabajo $\mathrm{N}^{\mathrm{o}} 45$, Santiago.

2003 Los aymaras contemporáneos. En Conozcamos Juntos la Historia y la Cultura de Nuestra Región, editado por A.M. Carrasco y B. Cofré, pp. 45-54. Taller de Estudios Andinos, Centro de Investigaciones del Hombre en el Desierto, Gobierno Regional de Tarapacá, Explora, Arica.

2004 La economía aymará actual de las comunidades rurales del norte de Chile. Manuscrito en posesión del autor.

2005 ¿Están las comunidades aymaras del norte de Chile en crisis? Una respuesta desde la demografía y la economía. Manuscrito en posesión del autor.

González, H. y A.M. Carrasco

1995 Caracterización de la Inserción Laboral de Mujeres Aymara, Primera Región de Tarapacá, Chile. SERNAMTaller de Estudios Andinos, Arica.

González, H. y E. Contreras

1994 Diagnóstico Micro-Regional San Pedro de Atacama. Instituto de Desarrollo Agropecuario-Corporación Norte Grande, San Pedro de Atacama.

González, H. y V. Gavilán

1989 Etnia, cultura e identidad aymara. Documentos de Trabajo, Taller de Estudios Andinos, Arica.

1993 Cultura e identidad étnica entre los aymara del norte de Chile. Chungara 24-25:145-158.

González, H. y B. Guerrero, editores

1990 Desarrollo Andino y Cultura Aymara en el Norte de Chile. El Jote Errante, Iquique.

González, H. y H. Gundermann

1989 Campesinos y aymaras en el norte de Chile. Documentos de Trabajo, Taller de Estudios Andinos, Arica.

1991 Diagnóstico de la situación campesina en el área de Guatacondo. Documentos de Trabajo, Taller de Estudios Andinos, Arica.

1994 Minorías étnicas e integración subregional. Si Somos Americanos, pp. 70-74. Universidad Arturo Prat, Iquique.

1996 Organizaciones aymaras, identidad étnica e integración. En La Integración Surandina Cinco Siglos Después, compilado por X. Albó, M. I. Arratia, J. Hidalgo, L. Núñez, A. Llagostera, I. Remy y B. Revesz, pp. 395-416. Centro de Estudios Regionales Andinos Bartolomé de Las Casas, Cusco.

González, H., H. Gundermann y R. Rojas

1990 Bases para la formulación de un programa tecnoproductivo con ganaderos Aymara. Documentos Técnicos, Taller de Estudios Andinos, Arica.

1993 Diagnóstico y Estrategia de Desarrollo Campesino en la I Región de Tarapacá, Chile. Ediciones Corporación Norte Grande, Arica. 
González, H. y J. Hidalgo

2001 La República y los indios. De indígenas a ciudadanos. En Pueblos del Desierto. Entre el Pacífico y los Andes, varios autores, pp. 107-109. Universidad de Tarapacá, Santiago.

González, H., K. Tabilo y F. Venegas

1996 Las agrupaciones de residentes aymara urbanos en el norte de Chile: adaptación a la ciudad y vínculos con las comunidades de origen. Documentos de Trabajo, Corporación Norte Grande, Arica.

González, J.

1987 Los hijos de la desintegración cultural: jóvenes aymaras emigrados. Centro de Investigación de la Realidad del Norte, Cuadernos de Investigación Social $\mathrm{N}^{\circ} 23$, Iquique.

1988 Vengo de la cordillera al mar. Migrantes aymaras en Iquique. Centro de Investigación de la Realidad del Norte, Serie Crónicas, Iquique.

1991 Jóvenes Inmigrantes Aymaras en Iquique: Situación y Perspectivas. Tesis para optar al título de Sociólogo, Universidad Católica del Norte, Antofagasta.

González, S.

1981 La planificación regional y las minorías étnicas: el caso de los aymaras. Cuaderno de Investigación Social 4:4-18.

1987 Los aymaras de Tarapacá en el ciclo del salitre. Camanchaca 5:39-44.

1988 La educación chilena en el altiplano aymara de Tarapacá. Una crítica a las teorías modernistas y reproductivistas. Taller de Estudios Regionales, Documentos de Trabajo $\mathrm{N}^{\circ}$ 8, Iquique.

1989 El arrieraje en Tarapacá durante el ciclo salitrero. Camanchaca 8:10-35.

1990a El aymara de la provincia de Iquique-Chile y la educación nacional. Taller de Estudios Regionales, Cuadernos de Educación Intercultural $N^{\circ} 1$, Iquique.

1990b Violencia y eficacia simbólica en la chilenización educativa de los aymaras de Tarapacá. Actas del Primer Seminario Internacional de Educación Intercultural, pp. 24-28. Taller de Estudios Regionales, Cuadernos de Educación Intercultural $\mathrm{N}^{\circ} 2$, Iquique.

1991 Hombres y Mujeres de la Pampa. Tarapacá en el Ciclo del Salitre. Ediciones Camanchaca, Iquique.

1993 Los aymaras de Isluga y Cariquima, un contacto con la chilenización y la escuela. Revista de Ciencias Sociales 3:1-6.

1995 Cochabambinos de habla quechua en las salitreras de Tarapacá, 1880-1920. Chungara 27:135-151.

1996a Quechuas y aymaras en las salitreras de Tarapacá. En $L a$ Integración Surandina Cinco Siglos Después, compilado por X. Albó, M.I. Arratia, J. Hidalgo, L. Núñez, A. Llagostera, I. Remy y B. Revesz, pp. 353-361. Centro de Estudios Regionales Andinos Bartolomé de Las Casas, Cusco.

1996b Civilizando al yatiri: la labor docente de los maestros normalistas en el mundo andino de la provincia de Iquique antes de la reforma educacional de 1965. Revista de Ciencias Sociales 6:3-58.

1997 La escuela chilena en los Andes de Tarapacá. En Pueblos Indígenas. Educación y Desarrollo, editado por A. Bello, A. Wilson, S. González y P. Marimán, pp. 81-95. CEDEM, Santiago.

1998 Una crítica a los paradigmas modernizantes y reproductivistas en la investigación educativa de los aymaras de Tarapacá. Estudios Atacameños 13:47-60.
1999 Interculturalidad y globalización: El caso de los aymaras de Tarapacá. Revista de Ciencias Sociales 9:139-152.

2000 Del refugio a la globalización: Reflexiones sobre el aymara chileno y la escuela pública en el siglo XX. En Educación y Pueblo Aymara, S. González, F. Mena, C. Chipana, C. González, H. Alegría y P. García, pp. 3-67. Universidad Arturo Prat, Instituto de Estudios Andinos Isluga, Iquique.

2001 Maestros rurales de la provincia de Arica en el contexto de las reformas educacionales, 1960 y 1990. Revista de Ciencias Sociales 11:41-70, Universidad Arturo Prat.

2001-2002 Violencia estructural en los Andes de Tarapacá. Diálogo Andino 20-21:11-35.

2002a Chilenizando a Tunupa. La Escuela Pública en el Tarapacá Andino (1880-1990). DIBAM, UNAP, Centro de Investigaciones Diego Barros Arana, Santiago.

2002b La presencia indígena, boliviana y chilena en el enclave salitrero de Tarapacá: una reflexión en torno a la fiesta de La Tirana. Si Somos Americanos III (2):121-146.

2002c Hombres y Mujeres de la pampa. Tarapacá en el Ciclo de Expansión del Salitre. Segunda edición. LOM, DIBAM, UNAP, Santiago.

2002d El Estado chileno y el mundo andino: los efectos de la Guerra del Pacífico. Comisión Verdad Histórica y Nuevo Trato, Documento de Trabajo $\mathrm{N}^{\circ} 46$, Santiago.

2006 La presencia indígena en el enclave salitrero de Tarapacá: una reflexión en torno a la fiesta de La Tirana. Chungara Revista de Antropología Chilena 38:35-49.

2009 La presencia boliviana en la sociedad del salitre y la nueva definición de la frontera: auge y caída de una dinámica transfronteriza (Tarapacá 1880-1930). Chungara Revista de Antropología Chilena 41:71-81.

González, Y.

1979 El niño aymara: socialización y desocialización. Tambo 1 (3-4).

1980 La familia aymara. Una estructura desintegrada y dominada. Cuaderno de Investigación Social 3:44-50.

1985 La estrategia de subsistencia en Chiapa: el control de los recursos. Cuaderno de Investigación Social $\mathrm{N}^{\circ} 12$, Centro de Investigación de la Realidad del Norte, Iquique.

González, Y. y L. Ramírez

1975 Algunos aspectos culturales de los habitantes limereños: su vida doméstica, trabajo y situación escolar. Cuaderno de Investigación Social 1:25-34.

1980 Hacia un Diagnóstico de la Familia Andina Actual. Tesis para optar al título de Sociólogo, Departamento de Sociología, Universidad del Norte, Antofagasta.

Grebe, M.

1980 Generative models, symbolic structure and acculturation in the panpie music of the aymara of Tarapacá, Chile. Doctoral Dissertation, Queen's University, Belfast.

1981 Cosmovisión aymara. Revista de Santiago 1:61-79.

1983 En torno a los ritos terapéuticos astrales de Islug. Chungara 10:155-164.

1984a Efectos socioculturales en cadena en el pastoreo de puna del norte de Chile. Ambiente y Desarrollo I-1:127131.

1984b Etnozoología andina: concepciones e interacciones del hombre andino con la fauna altiplánica. Estudios Atacameños 7:455-472.

1986a Migración, identidad y cultura aymará: puntos de vista del actor. Chungara 16-17:205-223. 
1986b Cambio sociocultural y bilingüismo aymara-español en Isluga. Lenguas Modernas 13:37-53.

1990a Concepción del tiempo en la cultura aymara: representaciones icónicas, cognición y simbolismo. Revista Chilena de Antropología 9:63-81.

1990b Patrones supralingüísticos en la cognición y simbolismo andino. En Actas del Primer Simposio sobre Cognición, Lenguaje y Cultura, editado por A. Bocaz, pp. 247-255. Universidad de Chile, Santiago.

1993 Algunas perspectivas interculturales en la religiosidad andina. Segundas Jornadas Interdisciplinarias "religión y cultura", trabajos presentados, pp. 63-71. Universidad de Chile, Santiago.

1994 Concepción del tiempo en las culturas indígenas sur-andinas. Time and Astronomy at the Meeting of the Two Worlds, editado por S. Iwaniszewski, A. Lebeuf, A. Wierciński y M. Ziółkowski, pp. 297-313. CESLA, UW, Serie Estudios y Memorias $\mathrm{N}^{\circ} 10$, Varsovia.

1995-1996 Continuidad y cambio en las representaciones icónicas: significados simbólicos en el mundo sur-andino. Revista Chilena de Antropología 13:137-154.

Grebe, M.E. y B. Hidalgo

1988 Simbolismo atacameño: un aporte etnológico a la comprensión cultural. Revista Chilena de Antropología 7:75-97.

Guerra, P.

1975 Guatacondo: un caso de transformación agraria y cultural en la zona árida. Norte Grande I (3-4):387-400.

Guerrero, B.

1975 Tres elementos configurativos en los cantos religiosos del Norte Grande de Chile. Cuaderno de Investigación Social 1:35-45.

1977 Dos fenómenos religiosos en la Fiesta de La Tirana: la oración y el sacrificio. Cuaderno de Investigación Social 2:31-40.

1978 Los Pentecostales y el Proceso de Desintegración de las Comunidades Indígenas del Norte Grande de Chile. Tesis para optar al título de Sociólogo, Departamento de Sociología, Universidad del Norte, Antofagasta.

$1980 \mathrm{La}$ estructura ideológica del movimiento pentecostal. Cuaderno de Investigación Social 3:1-12.

1981 La violencia pentecostal en la sociedad aymara. Cuaderno de Investigación Social 4:34-44.

1984 Movimiento pentecostal, corrientes modernistas y sociedad aymara. Cuaderno de Investigación Social $\mathrm{N}^{\circ}$ 8, Centro de Investigación de la Realidad del Norte, Iquique.

1986 El 'Boletín Aymara'. Un intento de sistematización. Cuaderno de Investigación Social $\mathrm{N}^{\mathrm{o}} 19$, Centro de Investigación de la Realidad del Norte, Iquique.

1987 El régimen pentecostal en la sociedad aymara del Norte de Chile. Actas del Primer Congreso Chileno de Antropología, 1985, pp. 303-315. Colegio Chileno de Antropólogos, Santiago.

1990 Las Campanas del Dolor. Violencia y Conflicto en los Andes Chilenos. Centro de Investigación de la Realidad del Norte, serie Crónicas, Iquique.

1992 Conversión y salud en el Altiplano chileno. Revista de Ciencias Sociales 1:19-23.

1993 Identidad aymara e identidad pentecostal. Notas para la discusión. Revista de Ciencias Sociales 3:15-24.

1994a A Dios Rogando... Los Pentecostales en la Sociedad Aymara del Norte Grande de Chile. Tesis Doctoral, Vrije University Press, Amsterdam. 1994b De la invisibilidad a la visibilidad académica: Estudios sobre el movimiento pentecostal en la sociedad andina. Diálogo Andino 13:39-48.

1995 Medicina andina y medicina pentecostal en los aymaras del norte grande de Chile: del yatiri al pastor. Chungara 27:153-165.

1997a Violencia y conflicto religioso entre los aymaras del Norte Grande de Chile. Diálogo Andino 16:61-78.

1997b Medicina andina y medicina evangélica: del Yatiri al Pastor. Actas del Segundo Congreso Chileno de Antropología, Vol. 2, pp. 754-766. Colegio de Antropólogos de Chile, Santiago.

1998 Violencia y conflicto religioso entre los aymaras del Norte Grande de Chile. Diálogo Andino 16:61-78.

Guerrero, B., J. Podestá y E. Pérez

1984 Los aymaras chilenos del Norte Grande. Primer Congreso Chileno de Sociología, editado por L. Solís, pp. 647-666. Colegio de Sociólogos de Chile, Santiago.

Guerrero, B., editor.

1996 Homenaje a Freddy Taberna G. Escritos Sobre la Sociedad Aymara del Norte Grande de Chile. El Jote Errante, Iquique.

Guerrero, V.

1996 Sociedad y política en los aymaras de Iquique. Revista de Ciencias Sociales 6:59-77.

Guevara, T.

1925-29 Historia de Chile: Chile Prehispano. 2 Vol. Imprenta Balcells, Santiago.

Gundermann, H.

1984a Contradicciones entre la realidad andina y los programas educacionales vigentes. Documentos de Trabajo, Universidad de Tarapacá, Proyecto IAF-UTA, Arica.

1984b Ganadería aymará, ecología y forrajes: Evaluación regional de una actividad productiva andina. Chungara 12:99-124.

1985a La experiencia organizativa y educacional de Lirima. Documentos de Trabajo, Universidad de Tarapacá, Proyecto IAF-UTA, Arica.

1985b La visión aymara de la escuela, los profesores y la educación. Documentos de Trabajo, Universidad de Tarapacá, Proyecto IAF-UTA, Arica.

1985 c Los profesores rurales y la sociedad andina. Documentos de Trabajo, Universidad de Tarapacá, Proyecto IAF-UTA, Arica.

1985d Los aymaras contemporáneos. En Culturas de Arica, editado por C. Santoro y L. Ulloa, pp. 93-98. Ministerio de Educación, Departamento de Extensión Cultural, Santiago.

1986 Comunidades ganaderas, mercado y diferenciación interna en el altiplano chileno. Chungara 16-17:233-250. 1987 Los aymaras en Chile: elementos de caracterización. Nütram III (2):40-46.

1988a La cultura material andina y el mercado. La descomposición de la manufactura casera aymara en el altiplano chileno. Resultados de Investigación, Taller de Estudios Andinos, Arica.

1988b Ganadería aymara, ecología y forrajes (Chile). En Llamichos y Paqocheros. Pastores de Llamas y Alpacas, compilado por J. Flores, pp. 101-112. CEAC-UNSAAC, Cuzco.

1990 Antecedentes socio-lingüísticos de la lengua aymara en el norte de Chile. Documentos de Trabajo, Taller de Estudios Andinos, Arica. 
1994 ¿Cuántos hablan en Chile la lengua aymara? Revista de Lingüística Teórica y Aplicada 32:125-139.

1995 Comunidad indígena y ciudadanía: La experiencia aymara en el norte de Chile. Allpanchis 46:91-130.

1995-1996 Acerca de cómo los aymaras aprendieron el castellano (terminando por olvidar el aymara). Estudios Atacameños 12:97-114.

1997 Etnicidad, identidad étnica y ciudadanía en los países andinos y el norte de Chile. Los términos de la discusión y algunas hipótesis de investigación. Estudios Atacameños 13:9-26.

1998a Pastoralismo andino y transformaciones sociales en el norte de Chile. Estudios Atacameños 16:293-319.

1998b Comunidad aymara, identidades colectivas y Estados nacionales en los albores del S. XX. En A 90 Años de los Sucesos de la Escuela Santa María de Iquique, varios autores, pp. 153-181. DIBAM, LOM, Universidad Arturo Prat, CIDBA, Santiago.

1998c Notas acerca de igualdad, identidad étnica y desarrollo en el norte de Chile. Revista de Ciencias Sociales 8:4964.

1999 Categorías de identidad en el discurso popular urbano del norte de Chile. Estudios Atacameños 17:25-32.

2000 Las organizaciones étnicas y el discurso de la etnicidad en el norte de Chile, 1980-2000. Estudios Atacameños 19:75-91.

2001 Comunidad, Sociedad Andina y Procesos Socio-Históricos en el Norte de Chile. Tesis Doctoral, Centro de Estudios Sociológicos, El Colegio de México, México.

2002a San Pedro de Atacama: Actores, procesos, imaginarios. En Retrato Hablado de las Ciudades Chilenas, editado por B. Guerrero, pp. 47-62. UNAP-Centro de Investigaciones Barros Arana, Santiago.

2002b Sociedad aymara y procesos de modernización durante la segunda mitad del siglo XX. Documentos de Trabajo $\mathrm{N}^{\circ} 38$, Comisión Verdad Histórica y Nuevo Trato, Santiago.

2002c Los atacameños del siglo XIX, una antropología histórica regional. Documentos de Trabajo $\mathrm{N}^{\circ}$ 51, Comisión Verdad Histórica y Nuevo Trato, Santiago.

2003a Sociedades indígenas, municipio y etnicidad. La transformación de los espacios políticos locales andinos en Chile. Estudios Atacameños 25:55-77.

2003b Las poblaciones indígenas andinas de Chile y la experiencia de la ciudadanía. En El Debate en Torno al Reconocimiento y los Derechos Ciudadanos. Mapuches y Aymaras, editado por H. Gundermann, R. Foerster y J. Vergara, pp. 19-104. Universidad de Chile y Ril Editores, Santiago.

2003c La formación del espacio andino en Arica y Tarapacá. Revista de Historia Indígena 7:87-138.

2004a Inicios de siglo en San Pedro de Atacama: procesos, actores e imaginarios en una localidad andina. Chungara Revista de Antropología Chilena 36:221-239.

2004b Sociedades andinas, municipio y etnicidad; la transformación de los espacios políticos locales andinos en Chile. En Los Desafíos de la Interculturalidad, Identidad, Política y Derecho, editado por M. Castro, pp. 291-328. Universidad de Chile, Santiago.

2005a Comunidad aymara y conflicto interno sobre la tierra en la región de Tarapacá, Chile, en Cuadernos Interculturales 3(5):43-66. 2005b Estudio del contexto sociolingüístico de comunidades aymara, atacameñas y mapuche de Chile. En Descripción del Contexto Sociolingüístico en Comunidades Indígenas de Chile, pp. 15-98. MIDEPLAN, ORIGENES, CONICYT, Santiago.

2006 Municipios y pueblos indígenas en Chile. En Movimientos indígenas y gobiernos locales en América Latina, editado por W. Assies y H. Gundermann. Universidad Católica del Norte, El Colegio de Michoacán, International Work Group for Indigenous Affaires (IWGIA), en prensa.

Gundermann, H. y C. Chipana

1986 Antecedentes sobre la familia aymara y su rol de socialización en un contexto de aculturación. Documentos de Trabajo, Universidad de Tarapacá, Proyecto IAF-UTA, Arica.

Gundermann, H. y H. González

1989 La Cultura Aymara. Artesanías Tradicionales del Altiplano. Ministerio de Educación, Departamento de Extensión Cultural y Museo Chileno de Arte Precolombino, Santiago.

1990 El actual Proyecto de Colonización de la Pampa del Tamarugal. Documentos Técnicos, Taller de Estudios Andinos, Arica.

1992 La Comunidad Andina en Chile: discusión y Antecedentes Preliminares. Campus Iquique III (20):72-87.

1993 Estudio de Diagnóstico Comuna de Ollagüe. I. Municipalidad de Ollagüe-Corporación Norte Grande, Arica.

1995 Tierra, agua y sociedad atacameña, un escenario cambiante. En Agua, ocupación del espacio y economía campesina en la región atacameña, editado por P. Pourrut y L. Núñez, pp. 78-106. Universidad Católica del NorteORSTOM, Antofagasta.

1997 Contribución a la historia de la propiedad aymara. Corporación Nacional de Desarrollo Indígena (CONADI), Santiago.

1999 Los aymaras y el tráfico regional de estupefacientes (algunas hipótesis de trabajo). Departamento de Ciencias Sociales, Universidad Arturo Prat, Iquique.

Gundermann, H., H. González y R. Rojas

1990 La ganadería Aymara de camélidos y la exportación de reproductores. Documentos de Trabajo, Taller de Estudios Andinos, Arica.

Gundermann, H., H. González y J.I. Vergara

2006 Vigencia y desplazamiento de la lengua aymara en Chile. Manuscrito en posesión de los autores.

Gundermann H., J.I. Vergara y R. Foerster

2005a Contar a los indígenas en Chile. Autoadscripción étnica en la experiencia censal de 1992 y 2002. Estudios Atacameños 30:91-115.

2005b La adscripción étnica de los pueblos andinos de Chile analizada a través de las cifras censales de 1992 y 2002. Revista Andina 41:9-61.

Guzmán, S.

1969 Elementos de Diagnóstico de las Comunidades Altiplánicas de Isluga, Provincia: Tarapacá. INCONOR, Iquique.

Hanson, E.

1926 Out-of-the-world villages of Atacama. Geographical Review 16:365-377.

Harmelink, B.

1985 Investigaciones Lingüisticas en el Altiplano chileno. Un estudio entre la Comunidad Aymara Chilena. Instituto Lingüístico de Verano y Universidad de Tarapacá, Arica. 
Henríquez, F.

1997-1998 Hacienda y Economía Colonial: Azapa en el Siglo XVIII. Tesis de Licenciatura en Historia, Instituto de Estudios Humanísticos, Universidad de Valparaíso, Valparaíso.

2003 Productos y organización técnica del trabajo en Azapa durante el siglo XVIII: Poniendo chacra de ají, cogiendo aceitunas. Chungara Revista de Antropología Chilena 35:125-140.

Hernández, R.

1974 Chiu-Chiu: la desintegración de la comunidad tradicional. Antropología. Nueva Época 1:17-35.

Hernández, R., P. Poblete y D. Quiroz

1975 Toconce: la vigencia de la comunidad tradicional. Antropología. Nueva Época 2:53-75.

Herrera, J.

1991 Reflexiones étnicas en torno a la costa de Arica. Diálogo Andino 10:73-87.

1998 El control político de las aguas en Tarapacá: poder y conflicto. Siglos XVI-XVIII. Actas IV Congreso Internacional de Etnohistoria Vol. 1, pp. 79-105. Pontificia Universidad Católica del Perú, Lima.

2000 Aspectos sociopolíticos sobre el derecho de agua en Tarapacá. Siglos XVII-XIX. En Manos Sabias para criar la Chacra Andina: Tecnologías Andinas, editado por J. van Kessel y H. Larraín, pp. 379-410. Abya-Yala/IECTA, Quito.

Hidalgo, B

1992 Organización Social, Tradición y Aculturación en Socaire, una Aldea Atacameña. 2 Vols. Tesis para optar al título de Antropólogo Social, Departamento de Antropología, Universidad de Chile, Santiago.

Hidalgo, J.

1978a Incidencia de los patrones de doblamiento en el cálculo de la población del Partido de Atacama desde 1752 a 1804. Las revisitas inéditas de 1787-1792 y 1804. Estudios Atacameños 6: 53-111.

1978b Revisita a los Altos de Arica Efectuada por el Oficial Real don Joaquín de Cárdenas en 1750. Departamento de Antropología, Universidad del Norte, Arica.

1981a Fechas coloniales de fundación de Toconao y urbanización de San Pedro de Atacama. Chungara 8:255-264.

1981b Culturas y etnias protohistóricas: Área Andina Meridional. Chungara 8:209-254.

1982a Fases de la rebelión indígena de 1781 en el corregimiento de Atacama y esquema de la inestabilidad política que la precede, 1749-1781. Chungara 9:192-231.

1982b Orígenes de la etnohistoria en Chile. Manuscrito en posesión del autor [republicado como Etnohistoria e interdisciplinariedad en Chile desde sus orígenes hasta 1980, en J. Hidalgo 2004: 655-684].

1983a Amarus y cataris: aspectos mesiánicos de la rebelión indígena de 1781 en Cusco, Chayanta, La Paz y Arica. Chungara 10:117-138.

1983b Dos documentos inéditos y un mapa de Cobija: informes del comisionado Dr. José Agustín de Arze, 1786-1787. Chungara 10:139-146.

1984a Descomposición cultural de Atacama en el siglo XVIII: Lengua, escuela, fugas y complementariedad ecológica. Simposio: Culturas Atacameñas desarrollado en Manchester, Inglaterra. XLIV Congreso Internacional de Americanistas, coordinado por B. Bitmann, pp. 221-249. Universidad del Norte, Antofagasta. 1984b Complementariedad ecológica y tributo en Atacama: 1683-1792. Estudios Atacameños 7: 22-442.

1985a Proyectos coloniales inéditos de riego del desierto: Azapa (Cabildo de Arica, 1619); Pampa Iluga (O’Brien, 1765) y Tarapacá (Mendizábal, 1807). Chungara 14:183222.

1985b Carta del Obispo de Arequipa sobre los indios del corregimiento de Arica: 1620-1638. Cuatro documentos inéditos. Chungara 15:77-98.

1985c Ecological complementarity and tribute in Atacama: 1683-1792. En Andean Ecology and Civilization, editado por S. Masuda, I. Shimada y C. Morris, pp. 161-184. Universidad de Tokio, Tokio.

1986 Indian Society in Arica, Tarapacá and Atacama, 17501793, and its Response to the Rebellion of Tupac Amaru. Doctoral Dissertation, University of London, Londres.

1987a Tierras, exacciones fiscales y mercado en las sociedades andinas de Arica, Tarapacá y Atacama, 1750-1790. En La Participación Indígena en los Mercados Surandinos, compilado por O. Harris, B. Larson y E. Tandeter, pp. 193-235. CERES, La Paz.

1987b Cacicazgos del sur occidental andino: origen y evolución colonial. En Chiefdoms in the Americas, compilado por R. Drenan y C. Uribe, pp. 289-297. University Press of America, Boston.

1996a Relaciones protohistóricas interétnicas entre las poblaciones locales y altiplánicas en Arica. En La Integración Surandina Cinco Siglos Después, compilado por X. Albó, M. I. Arratia, J. Hidalgo, L. Núñez, A. Llagostera, I. Remy y B. Revesz, pp. 161-173. Centro de Estudios Regionales Andinos Bartolomé de Las Casas, Cusco.

1996b Rebeliones andinas en Arica, Tarapacá y Atacama, 1770-1781. En Entre la Retórica y la Insurgencia: las Ideas y los Movimientos Sociales en los Andes, Siglo XVIII, compilado por Ch. Walker, pp. 173-204. Centro de Estudios Regionales Andinos Bartolomé de Las Casas, Cusco.

1997 Los yungas de Tarata en el siglo XVIII. En Antropología, Arqueología e Historia de los Andes. Homenaje a María Rostworowski, editado por R. Varón y J. Flores, pp. 425442. Instituto de Estudios Peruanos-Banco Central de la Reserva, Lima.

1999-2000 Dominación y resistencia en el Cacicazgo de Pica. Revista de Historia Indígena 4:49-74.

2003 Pescadores del litoral árido de valles y quebradas del norte de Chile y su relación con agricultores, Siglos XVI y XVII. En Arqueología y Etnohistoria Andina: Contribuciones y Procedimientos, editado por J. Topic. Instituto de Investigaciones Andinas-Instituto de Estudios Peruanos, Lima, en prensa.

2004 Historia Andina en Chile. Editorial Universitaria, Santiago.

2009 Civilización y fomento: la 'descripción de Tarapacá' de Antonio O'Brien, 1765. Chungara Revista de Antropología Chilena 41:5-44.

Hidalgo, J. y P. Arévalo

1987 Atacama antes y después de la rebelión de 1781: Siete documentos inéditos del Archivo General de la Nación Argentina (A.G.A). Chungara 18:91-100.

Hidalgo, J., P. Arévalo, M. Marsilli y C. Santoro 1988 Padrón de la doctrina de Belén en 1813. Un caso de complementariedad tardía. Documentos de Trabajo 4:9-39. 
Departamento de Arqueología, Universidad de Tarapacá, Arica.

Hidalgo, J. y N. Castro

1997 Fiscalidad, punición y brujerías. Atacama, 1749-1755.

Estudios Atacameños 13:30-65.

1999 Rebelión y carnaval Ingaguasi (San Pedro de Atacama) 1775-1777. Estudios Atacameños 17:61-90.

Hidalgo, J., N. Castro y S. González

2004 La Revisita de Codpa (Altos de Arica) de 1772-73 efectuada por el corregidor Demetrio Egan. Chungara Revista de Antropología Chilena 36:103-112.

Hidalgo, J., J. Chacama y G. Focacci

1982 Elementos estructurales en la cerámica del estadio Aldeano. Chungara 8:79-95.

Hidalgo, J. y V. Díaz

1985 Cartas del Obispo de Arequipa sobre los indios del corregimiento de Arica: 1620-1638. Cuatro documentos inéditos. Chungara 15:77-97.

Hidalgo, J. y A. Durston

1998 Reconstitución étnica colonial en la sierra de Arica: el Cacicazgo de Codpa, 1650-1780. Actas del IV Congreso Internacional de Etnohistoria Vol. 2, pp. 32-75. P. Universidad Católica del Perú, Fondo Editorial, Lima.

Hidalgo, J., A. Durston, V. Briones y N. Castro

1997 El cacicazgo de Tacna: Un proceso de etnogénesis colonial, siglos XVI-XVIII. Actas del XIV Congreso Nacional de Arqueología Chilena, pp. 251-268. Sociedad Chilena de Arqueología y Museo Regional de Atacama, Copiapó.

Hidalgo, J., A.M. Farías, L. Guzmán y P. Arévalo

1988-1989 La mita de Azapa. 1680-1752. Un nuevo caso de mita local. Diálogo Andino 7-8:57-79.

Hidalgo, J. y G. Focacci

1986 Multietnicidad en Arica, siglo XVI. Evidencias etnohistóricas y arqueológicas. Chungara 16:137-147.

Hidalgo, J. y H. González

2003 El mundo indígena post-hispánico. En Conozcamos Juntos la Historia y la Cultura de Nuestra Región, editado por A.M. Carrasco y B. Cofré, pp. 45-54. Taller de Estudios Andinos, Centro de Investigaciones del Hombre en el Desierto, Gobierno Regional de Tarapacá, Explora, Arica.

Hidalgo J., N. Hume, M. Marsilli y R. Correa, transcriptores 1992 Padrón y Revisita de Atacama del Corregidor Alonso de Espejo, ordenada por el virrey Duque de La Palata. AGNA, Sala IX 7:7:1, 52 fs. (Año 1683). Estudios Atacameños 10:79-124.

Hidalgo, J. y V. Manríquez

1992 Mercados y etnicidad: lecturas de la Revisita de Atacama de 1683. Estudios Atacameños 10:149-167.

Hidalgo, J., M. Marsilli y P. Arévalo

1991 Complementariedad andina y la expansión de las haciendas en el valle de Lluta y la sierra de Arica: 1730-1838. Actas del XI Congreso Nacional de Arqueología Chilena Vol. 2, pp. 31-41. Museo Nacional de Historia Natural y Sociedad Chilena de Arqueología, Santiago.

Hidalgo, J., M. Marsilli y C. Ruiz

1990 Composición de tierras en el Corregimiento de Arica: La visita de Diego de Baños y Sotomayor en 1643. Historia 25:175-206.

Hidalgo, J., M. Marsilli, C. Santoro y R. Correa 1990 La compraventa de una hacienda en el valle de Azapa por Gaspar de Oviedo, 1161. Documento inédito del Archivo
General de la Nación, Lima-Perú. Diálogo Andino 9:83106.

Hidalgo, J., V. Schiappacasse, H. Niemeyer, C. Aldunate y J. Solimano, editores

1989 Culturas de Chile. Prehistoria Desde sus Orígenes Hasta los Albores de la Conquista. Andrés Bello, Santiago.

Hidalgo, J., V. Schiappacasse, H. Niemeyer, C. Aldunate, P. Mege, editores

1996 Culturas de Chile. Etnografía, Sociedades Indígenas Contemporáneas y su Ideología. Andrés Bello, Santiago.

Jiménez, C. y R. Seguel

2003 De lo técnico profesional a lo social: un proceso transhumántico. Chungara Revista de Antropología Chilena 35:315-320.

Jofré, D.

2003a Arqueología y Patrimonio de Belén: Paisaje y Continuidad Cultural al Interior de Arica. Tesis para optar al título de Arqueólogo, Departamento de Antropología, Universidad de Chile, Santiago.

2003b Una propuesta de acercamiento al patrimonio arqueológico de la comunidad de Belén (Región de Tarapacá, Chile). Chungara Revista de Antropología Chilena 35:327-335.

Kearney, M.

1996 Reconceptualizing the Peasantry. Anthropology in Global Perspective. Westview Press Boulder, Colorado.

Keller, C.

1946 El Departamento de Arica. Ministerio de Economía y Comercio, Santiago.

Lagos, R., E. Mendoza, N. Ampuero y N. Hernández

1982 La Noche de los abuelos en Santiago de Río Grande. Chungara Revista de Antropología Chilena 9:247-274.

1988 La limpia de canales y acequias de Santiago de Río Grande. Chungara 21:43-78.

1995-1996 Aspectos rituales relacionados con el ganado en Santiago de Río Grande (II Región, Chile). Estudios Atacameños 12:115-134.

Lanino, I.

1977a Antecedentes de las Explotaciones Ganaderas en Isluga, Altiplano de la Provincia de Iquique. Universidad del Norte, Centro Isluga, Iquique.

1977b Antecedentes de las Explotaciones Agrícolas en Isluga. Altiplano de la Provincia de Tarapacá. Universidad del Norte, Centro Isluga, Iquique.

Larraín, $\mathrm{H}$.

1974a Antecedentes históricos para un estudio de la reutilización de suelos agrícolas en la pampa del Tamarugal, provincia de Tarapacá, Chile. Norte Grande I (1):9-22.

1974b Demografía y asentamientos de los pescadores costeros del sur peruano y norte chileno, según informes del cronista Antonio Vásquez de Espinoza (1617-1618). Norte Grande I (1):55-81.

1974c Análisis de las causas de despoblamiento entre las comunidades indígenas del Norte Grande, con especial referencia a las hoyas hidrográficas de las Quebradas de Aroma y Tarapacá. Norte Grande I (2):125-154.

1975 La población indígena de Tarapacá (norte de Chile) entre 1538 y 1581. Norte Grande I (3-4):269-300.

1978-1979 Identidad cultural e indicadores eco-culturales del grupo étnico chango. Norte Grande 6:63-76.

1987 Etnogeografía. Instituto Geográfico Militar, Colección Geografía de Chile, Tomo XVI, Santiago. 
1989 El Desarrollo entre las Comunidades Atacameñas del Hinterland de Antofagasta. Posibles Directrices, Problemas y Experiencias Recientes. Autoedición, Antofagasta.

1991 Limpia de Canales de Toconce: Descripción de una ceremonia-faena tradicional. Hombre y Desierto 5:3-19.

Larraín, H. y R. Couyoumdjian

1975 El plano de la Quebrada de Tarapacá de don Antonio

O’Brien. Su valor geográfico y socio-antropológico. Norte Grande I (3-4):329-362.

Larraín, H. y E. Ross

1988 Historia y evolución de los Comités de Artesanos en pueblos situados en el hinterland de la II Región, Antofagasta. Hombre y Desierto 2:89-104.

Latcham, R.

1910 Los Changos de las Costas de Chile. Imprenta Cervantes, Santiago.

1915 Costumbres Mortuorias de los Indios de Chile y Otras Partes de América. Imprenta-Litografía Barcelona, SantiagoValparaíso.

1928 La Prehistoria Chilena. Imprenta y Litografía Universo, Santiago.

1929 Las Creencias Religiosas de los Antiguos Peruanos. Imprenta Balcells, Santiago.

1938 Arqueología de la Región Atacameña. Prensas de la Universidad de Chile, Santiago.

Lecaros, M.

1986 Dos documentos sobre Tarata: siglos XIX-XX. Diálogo Andino 5:105-115.

Lehnert, R.

1976 La lengua kunza y sus textos. Cuadernos de Filología 5:71-80.

1978 Préstamos del quechua y castellano a la lengua kunza. Revista de Lingüística Teórica y Aplicada 16:135-140.

1982 Presencia del runa-simi en el sector atacameño. Cuadernos de Filología 15-16:29-47.

1987 En torno a la lengua kunza. Language Sciences 9 (1):103-112.

1988 Vigencia del mito andino del zorro en las comunidades atacameñas. América Indígena 48 (4):753-72.

1993 El mito de Tunupa-Illapa en tierras atacameñas. América Indígena 53 (3):153-163.

1994 Diccionario de Toponimia Kunza. Universidad de Antofagasta, Instituto de Investigaciones Antropológicas, Antofagasta.

1995 Agua y religiosidad en el sector atacameño. América Indígena 55 (3):161-178.

1998 Antroponimia Indígena de la II Región. Universidad de Antofagasta, Instituto de Investigaciones Antropológicas, Antofagasta.

1999a Evolución de los nombres atacameños en el Libro de Varias Ojas de la Parroquia de Chiuchiu, 1611-1698. Boletín de Filología 37 (1):659-668.

1999b Atacama Colonial. Universidad de Antofagasta, Instituto de Investigaciones Antropológicas, Antofagasta.

1999c Zooépica Atacameña: Estudio de Relatos Orales de las Comunidades Atacameñas de la Segunda Región, Chile. Universidad de Antofagasta, Instituto de Investigaciones Antropológicas, Antofagasta.

2000 Mitos y Creencias del MundoAtacameño. Universidad de Antofagasta, Instituto de Investigaciones Antropológicas, Antofagasta.
2002 Diccionario Normalizado de la Lengua Cunsa. Universidad de Antofagasta, Instituto de Investigaciones Antropológicas, Antofagasta.

Lehnert, R., W. Reyes y J. Siares

1997 Rescate y Recopilación de la Lengua Kunza. [Sin datos de edición], San Pedro de Atacama.

Lemereis, J.

1987 La lucha por las aguas de los Aymaras del Norte Grande de Chile. Cuaderno de Investigación Social $\mathrm{N}^{\circ} 20$, Centro de Investigación de la Realidad del Norte, Iquique.

Luque, J.

1998 Los hombres de bronce: una aproximación a la construcción de la masculinidad de los varones aymaras de la Primera Región de Tarapacá. Programa Interdisciplinario de Estudios de Género, Universidad de Chile, Santiago.

Mamani, B. y J. Vilca

1989 La legislación de aguas en Chile y sus consecuencias destructivas para la comunidad y cultura aymara. La Visión India: Tierra, Cultura, Lengua y Derechos Humanos. Ponencias de un simposio que se llevó a cabo en el marco del 46o Congreso Internacional de Americanistas, Ámsterdam, Holanda, julio 1988, pp. 45-61. Musiro, Fundación para la Cultura de los Indígenas de las Américas, Leiden.

Mamani, J.C.

2003 Los Rostros del Aymara en la Provincia de Parinacota, Región de Tarapacá, Chile. Tesis para optar al grado de Magíster en Educación Intercultural Bilingüe, Mención Planificación y Gestión, Programa de Educación Intercultural Bilingüe para los Países Andinos, Universidad Mayor de San Simón, Cochabamba.

Mamani, M.

1982 Bilingüismo y su Problemática Educacional en la Provincia de Parinacota. Universidad de Tarapacá, Arica. 1985 Ensayo de Topónimos más Comunes de la I Región de Tarapacá. Imprenta Lincoyán, Arica.

1988-1989 Rol de la música en el ritual, marca y floreo del ganado en el altiplano chileno. Diálogo Andino 7-8:25-42.

1989 Structure of the livestock marking ritual of the Chilean Andes. Master of Art Dissertation in Latin American Studies, Center for Latin American Studies, University of Florida. 1994 Antecedentes míticos y ecológicos del significado del vocablo Chungara. Chungara 26:117-124.

1996 Estudio del sistema de tratamiento medicinal aymara, el caso del rito turkayaña. Actas del Segundo Congreso Chileno de Antropología, Vol. 1, pp. 354-360. Colegio de Antropólogos de Chile A. G., Santiago.

1999 Chacha-warmi. Paradigma e identidad matrimonial aymara en la provincia de Parinacota. Chungara Revista de Antropología Chilena 31:307-317.

2002 Diccionario Práctico Bilingüe Aymara-Castellano, Zona Norte de Chile. Suma Chuymamp Parlt'asiñani. EMELNOR NORprint, Antofagasta.

Mamani, M. y M. Luque

1997 Estudio del sistema de tratamiento medicinal de la enfermedad Anim-Aparata. Informe de investigación, Universidad de Tarapacá, Arica.

Manríquez, V.

1999-2000 Proposiciones sobre la existencia de "identidad" o "identidades" en la localidad colonial de Caspana. Un acercamiento desde los archivos parroquiales. Revista de Historia Indígena 4:103-125. 
Manríquez, V. y S. Sánchez

2003 Memorias de la sangre, memorias de la tierra: Pertenencia, identidad y memoria entre los indígenas del noroeste argentino, Atacama y Chile Central durante el período colonial. Estudios Atacameños 26:45-60.

Marsilli, M. y J. Hidalgo

1992 Haciendas y comunidades andinas en los valles costeros del norte de Chile, siglos XVIII y XIX. En Comunidades Indígenas y su Entorno, editado por M. Orellana y J. Muñoz, pp. 175-206. Universidad de Santiago de Chile, Santiago.

Martínez, G.

1974 Humor y sacralidad en el mundo autóctono andino. Publicación $\mathrm{N}^{\circ}$ 5. Universidad de Chile, Iquique.

1975a Introducción a Isluga. Publicación $\mathrm{N}^{\circ} 7$, Universidad de Chile, Iquique

1975b Características de orden antropológico y socioeconómico de la comunidad de Isluga (I Región). Norte Grande I (3-4):403-426.

1976 El sistema de los Uywiris en Isluga. En Homenaje al Dr. Gustavo Le Paige s.j., pp. 255-328. Universidad del Norte, Antofagasta.

1987 Para una etnografía del riego en Chiapa. Medidas y calendario. Chungara 18:163-179.

1989 Espacio y Pensamiento. I. Andes Meridionales. Hisbol, La Paz.

Martínez, J.L.

1985a Adaptación y cambio en los atacameños. Los inicios del período colonial, siglos XVI y XVII. Andes 3:9-25.

1985b La formación del actual pueblo de Toconce (Siglo XIX). Chungara 15:99-124.

1985c Información sobre el comercio de pescado entre Cobija y Potosí, hecha por el Corregidor de Atacama, don Juan de Segura (19 de julio de 1591). Cuadernos de Historia 5:161-171.

1986 Los grupos indígenas del Altiplano de Lípez en la Subregión del río Salado. Chungara 16-17:199-201.

1988 Dispersión y movilidad en Atacama colonial. En Encuentro de Etnohistoriadores, editado por O. Silva, E. Medina y E. Téllez, pp. 53-69. Universidad de Chile Santiago.

1990a Asentamientos y acceso a recursos en Atacama (siglo XVII). En Economía y Comercio en América Hispana, editado por G. Bravo, pp. 13-61. Universidad de Chile, Santiago.

1990b Interetnicidad y complementariedad en el Altiplano meridional. Andes 1:11-30.

1992a Textos y palabras. Cuatro documentos del siglo XVI. Estudios Atacameños 10:133-147.

1992b Acerca de las etnicidades en la Puna Árida en el siglo XVI. En Etnicidad, economía y simbolismo en los Andes. II Congreso Internacional de Etnohistoria, Coroico, compilado por S. Arze, R. Barragán, L. Escobari y X. Medinacelli, pp. 35-65. HISBOL/IFEA/SBH-ASUR, La Paz.

1994 Relaciones y negociaciones entre las sociedades indígenas de la región atacameña, y el Estado y la sociedad chilenos. Revista Proposiciones 24:201-207. Santiago.

1995a Papeles distantes, palabras quebradas. Las informaciones sobre Lipes en el siglo XVI. En Espacio, Etnias, Frontera. Atenuaciones Políticas en el Sur del Tawantinsuyu, Siglos $X V$-XVIII, compilado por A.M. Presta, pp. 285-317. Ediciones ASUR, Sucre.

1995b Autoridades en los Andes. Los Atributos del Señor. Pontificia Universidad Católica del Perú, Fondo Editorial, Lima. 1995c Entre plumas y colores: aproximaciones a una mirada cuzqueña sobre la puna salada. Memoria Americana 4:3356.

1996 'Pública voz y fama': una aproximación a los espacios discursivos coloniales en el siglo XVI. Revista Chilena de Humanidades 16:27-40.

1998 Pueblos del Chañar y el Algarrobo: los Atacamas en el Siglo XVII. Dirección de Bibliotecas, Archivos y Museos y Facultad de Filosofía y Humanidades de la Universidad de Chile, Santiago.

2000a Documentos y discursos. Una reflexión desde la etnohistoria. En Los Discursos Sobre los Otros (Una Aproximación Metodológica Interdisciplinaria), editado por J.L. Martínez, pp. 9-24. Facultad de Filosofía y Humanidades de la Universidad de Chile y LOM Ediciones, Santiago.

$2000 \mathrm{~b}$ Voces, discursos e identidades coloniales en los Andes del siglo XVI. En Los Discursos Sobre los Otros (Una Aproximación Metodológica Interdisciplinaria), editado por J.L. Martínez, pp. 127-158. Facultad de Filosofía y Humanidades de la Universidad de Chile y LOM Ediciones, Santiago.

2000c Invasiones, procesos y estrategias culturales. Los siglos XV y XVI en la puna árida y el desierto. En Las Rutas del Capricornio Andino, editado por R. Spotorno, pp. 47-56. Dirección de Bibliotecas, Archivos y Museos, Santiago.

2000d Ayllus e identidades interdigitadas. Las sociedades de la puna salada. En Lógica Mestiza en América, editado por G. Boccara y S. Galindo, pp. 85-112. Universidad de La Frontera, Temuco.

2002 La construcción de identidades y de lo identitario en los estudios andinos (ideas para un debate). En Identidades y Sujetos. Para una Discusión Latinoamericana, editado por J.L. Martínez, pp. 89-112. Facultad de Filosofía y Humanidades de la Universidad de Chile, Santiago.

2003 El fracaso de los discursos: el desencuentro de Cajamarca. En Los Andes 50 Años Después (1953-2003): Homenaje a John Murra, compilado por A.M. Lorandi, C. Salazar-Soler y N. Wachtel, pp. 171-205. Pontificia Universidad Católica del Perú, Lima.

2004a ¿Cómo se hablaba de indios e identidades en el siglo XVI? Una aproximación a la construcción de los discursos coloniales. Revista de Historia Indígena 8:41-55.

2004b Discursos de alteridad y Conjuntos significantes andinos. Chungara Revista de Antropología Chilena 36:505-514.

2004c Pratiques discursives coloniales d'identité. Le cas des Lipes au XVIe siècle. Tesis Doctoral, Escuela de Altos Estudios en Ciencias Sociales, París.

2006 Las sociedades del altiplano meridional andino (puna salada): una aproximación desde los relatos cuzqueños y aymaras. En Esferas de Interacción Prehistóricas y Fronteras Nacionales Modernas: los Andes Sur Centrales, editado por H. Lechtman, pp. 263-291. Instituto de Estudios PeruanosInstitute of Andean Research, Lima.

Martínez, J.L., A.M. Farías, V. Manríquez y C. Sanhueza

1991 Interetnicidad y complementariedad: dinámicas de las estrategias de supervivencia de los atacameños en el siglo XVII. Histórica 15 (1):27-42, Lima.

Martínez, J.L., V. Gallardo y N. Martínez

2002 Construyendo identidades desde el poder: los indios en los discursos republicanos de inicios del siglo XIX. En Mestizaje, Identidades y Poder en las Américas, editado por G. Boccara, pp. 27-46. Abya-Yala-IFEA, Quito. 
Matus, A.

1993-1994 El ceremonial de la limpia de canales en Caspana. Revista Chilena de Antropología 12:65-86.

Medina, J.T.

1882 Los Aboríjenes de Chile. Imprenta Gutenberg, Santiago.

1930 Bibliografía de las Lenguas Quechua y Aymará. Museum of American Indian, Heye Foundation, New York.

Mercado, C., P. Rodríguez y M. Uribe

1996 Tiempo de Verde, Tiempo de Lluvia: Carnaval en Aiquina. LOM, Santiago.

1997 Pa' que Coman las Almas. La Muerte en el Alto Loa. LOM, Santiago.

Miranda, P.

1997 Julian Colamar Recuerda: Visiones de Caspana. Fondo de Desarrollo de las Artes y la Cultura, Ministerio de Educación, Santiago.

Morales, $\mathrm{H}$.

1997 Pastores Transhumantes del Fin del Mundo. Un Enfoque Cultural de la Tecnología en una Comunidad Andina de Pastores. Tesis para optar al título de Antropólogo Social, Departamento de Antropología, Universidad de Chile, Santiago.

Mostny, G.

1954 Peine, un pueblo atacameño. Publicación $N^{\circ}$ 4, Instituto de Geografía, Universidad de Chile, Santiago.

Munizaga, C.

1963 Un médico herbolario de la actualidad en el norte de Chile. Revista Universitaria 26:243-251.

Munizaga, C. y H. Gunckel

1958 Notas etnobotánicas del pueblo atacameño de Socaire. Publicaciones del Centro de Estudios Antropológicos 5:9-40. Universidad de Chile, Santiago.

Muñoz, B.

1993a Procesos de Cambios Sociales en el Área de San Pedro de Atacama: Pérdida y Recuperación de la Identidad Étnica, una Contribución Antropológica al Desarrollo. Tesis Doctoral, Holos, Bonn.

1993b Procesos atacameños actuales: carácter y funcionamiento de las instituciones indígenas que otorgan identidad étnica. Nütram IX (3-4):51-62.

Muñoz, E. y M. Pedrero

2002 Facilitadores Interculturales en el Servicio de Salud Arica ¿Una Experiencia de Interculturalidad en Salud? CEDEMU, Arica.

Murra, J.

1975 Formaciones Económicas y Políticas del Mundo Andino. Instituto de Estudios Peruanos, Lima.

1978 La Organización Económica del Estado Inca. Editorial Siglo XXI, México.

Neumann, P. y V. Solc

1968 Chile-Expedition 1996/67. EAZ EthnographishArchäologische-Zeitschrift 9:78-79.

Núñez, L.

1985 Recuérdalo, aquí estaba el lagar: la expropiación de las aguas del Valle de Quisma (I Región). Chungara 14:157167.

1992 Cultura y Conflicto en los Oasis de San Pedro de Atacama. Editorial Universitaria, Santiago.

1996 La Universidad Católica del Norte y su misión antropológica en el desierto chileno. En La Universidad
Católica del Norte y el Desarrollo Regional Nortino, editado por J. González, pp. 209-245. Ediciones Universitarias, Antofagasta.

Núñez, M.

1998 Peine: Saber andino, manejo de recursos y transformaciones. Estudios Atacameños 16:283-292.

2000 Movimientos y Voces en Peine. Tesis de Licenciatura en Antropología, Escuela de Antropología, Universidad Academia de Humanismo Cristiano, Santiago.

2002 Transformaciones Culturales en Toconao por Impacto de Empresas Mineras: un Estudio de Caso en el Norte de Chile. Tesis para optar al grado de Magíster en Antropología y Desarrollo, Escuela de Postgrado, Facultad de Ciencias Sociales, Universidad de Chile, Santiago.

Odone, $\mathrm{C}$.

1994 La Territorialidad Indígena Española en Tarapacá Colonial (Siglos XVI-XVIII): una Proposición. Tesis de Licenciatura en Historia, Instituto de Historia, Universidad Católica de Chile, Santiago.

1995 El tejido de las estrategias de distribución y circulación espacial en Tarapacá: un registro colonial. Memoria Americana 4:57-80.

Olmos, O.

1987 Algunas notas sobre la historia de los aymaras. Documento de Trabajo $\mathrm{N}^{\mathrm{o}}$ 1, Taller de Estudios Regionales, Iquique.

1988a Derechos indígenas y nuevo escenario: legislación chilena y pueblos indígenas. Apuntes preliminares para el caso aymara. Documentos de Trabajo $\mathrm{N}^{\circ}$ 5, Taller de Estudios Regionales, Iquique.

1988b Recursos hídricos y comunidades campesinas aymaras: apuntes preliminares sobre la problemática del agua. Documentos de Trabajo $\mathrm{N}^{\circ}$ 6, Taller de Estudios Regionales, Iquique.

Olmos, O. y E. Pérez

1988a Derechos humanos y pueblos indígenas: territorialidad y legislación en los aymaras del norte de Chile. Documentos de Trabajo $\mathrm{N}^{\circ} 11$, Taller de Estudios Regionales, Iquique. 1988b Actividades productivas y el cómputo del tiempo entre los aymaras del norte de Chile. Documentos de Trabajo $\mathrm{N}^{\circ} 17$, Taller de Estudios Regionales, Iquique.

Ortega, M.

1999a By Reason or by Force: Islugueño Identity and Chilean Nationalism. Doctoral Dissertation, Department of Social Anthropology, University of Cambridge, Cambridge.

1999b Escatología andina: metáforas del alma. En Los Vivos y los Muertos. Duelo y Ritual Mortuorio en los Andes, editado por J. van Kessel, pp. 165-183. IECTA, Iquique.

2001 Escatología andina: metáforas del alma. Chungara Revista de Antropología Chilena 33:253-258.

Ortiz, C.

1995 El Archivo Parroquial de Camiña, en Torno a su Discursividad. Una Aproximación al Bautizo y la Función de los Padrinos en la Estructura de Parentesco de los Naturales en el Siglo XVII. Tesis para optar al grado de Magíster en Historia, Mención Etnohistoria, Escuela de Postgrado, Facultad de Filosofía y Humanidades, Universidad de Chile, Santiago.

1998 En torno al archivo parroquial de Camiña: Una aproximación al documento y a su estructura ideológica. Revista de Historia Indígena 3:77-92. 
Paz Soldán, M.F.

1865 Atlas Geográfico del Perú. Imprenta Augusto Durand, París.

1877 Diccionario Geográfico Estadístico del Perú. Imprenta del Estado, Lima.

Pedrero, $\mathrm{M}$.

1997 Salud y Pueblos Indígenas. Enfoques y Experiencias en el Norte de Chile. CIDES, Arica.

2002 Mujeres Indigenas y Derechos Sexuales y Reproductivos. Elementos para el Debate. CEDEMU, Arica.

2004 Sistema Médico Aymará. Comentarios Generales. Programa Capacitación Continua, Servicio de Salud, Arica.

Pérez, E.

1975 La sociedad andina: una sociedad desintegrada. Cuaderno de Investigación Social 1:46-63.

1977 La movilidad de la mano de obra, factor necesario en el archipiélago vertical. Cuaderno de Investigación Social 2:25-30.

1978 Desarrollo y Desintegración: Un Estudio de las Comunidades Indígenas del Altiplano del Norte Grande de Chile. Tesis para optar al título de Sociólogo, Departamento de Sociología, Universidad del Norte, Antofagasta.

1981 Trabajo y tecnología tradicional andina. Cuaderno de Investigación Social 4:45-55.

1984 Políticas de desarrollo en la zona interior y altiplano: Tarapacá, Chile. Cuaderno de Investigación Social $\mathrm{N}^{\circ}$ 9, Centro de Investigación de la Realidad del Norte, Iquique.

1988a Cambios en la especialización productiva ganadera de los aymaras: sector Isluga y Cariquima. Documentos de Trabajo $\mathrm{N}^{\mathrm{o}}$ 2, Taller de Estudios Regionales, Iquique.

1988b Organización y campesinado aymara: Isluga y Cariquima. Documento de Trabajo $\mathrm{N}^{\circ}$ 9, Taller de Estudios Regionales, Iquique.

1988c La economía agraria andina, un espacio no reconocido. Documento de Trabajo № 14, Taller de Estudios Regionales, Iquique.

1990a La cultura y el movimiento indígena regional del norte chileno. Documentos de Trabajo, Taller de Estudios Regionales, Iquique.

1990b Chamaka. Se fue con la camanchaca. Camanchaca 11:8-12.

Pérez, M.S.

2003 Medicina tradicional y medicina occidental en el pueblo de Talabre. Ponencia en Actas del 51 Congreso de Americanistas, Santiago, manuscrito en posesión del autor.

2005 Significados de la Salud Enfermedad en el Pueblo de Talabre. Un Acercamiento Desde la Perspectiva de Género. Tesis para optar al grado de Magíster en Género y Cultura en América Latina, Centro de Estudios de Género y Cultura en América Latina, Facultad de Filosofía y Humanidades, Universidad de Chile, Santiago (también en www.ciudadaniasexual.org).

Phillipi, R.

1860 Viage al Desierto de Atacama Hecho de Orden del Gobierno de Chile en el Verano 1853-1854. Librería Eduardo Antón, Halle, Sajonia.

Pizarro, L.

1988 Algunas reflexiones acerca de los espacios femeninos, masculinos en las comunidades aymaras del sector de Isluga.
Taller de Estudios Regionales, Documentos de Trabajo $\mathrm{N}^{\mathrm{o}} 10$, Iquique.

1990 La tradición textil de Isluga. Camanchaca 11:34-36. Platt, T.

1975a Experiencia y experimentación: Los asentamientos andinos en las cabeceras del valle de Azapa. Chungara 5:33-60.

1975b Reseña de 'Chiu Chiu: La desintegración de la comunidad tradicional' de Roberto Hernández Aracena. Chungara, Revista de Antropología Chilena 5:153-158.

Podestá, J.

1975 Notas demográficas sobre Camiña y Sibaya comprendiendo el período 1600-1900. Cuaderno de Investigación Social 1:10-24.

1976 La sociedad andina contemporánea. Un análisis funcional. Cuaderno de Investigación Social 2:2-8.

1980 Funciones socio-políticas y culturales de la educación chilena en el altiplano aymara. Cuaderno de Investigación Social 3:13-43.

1981a Influencias de la Educación Fiscal en las Comunidades Aymaras del Norte Grande Chileno. Tesis para optar al título de Sociólogo, Departamento de Sociología, Universidad del Norte, Antofagasta.

1981b Dualidad de sistemas educacionales en el altiplano andino. Un cuadro comparativo de sus bases formales. Cuaderno de Investigación Social 4:19-26.

1987 ¿Educación popular o etnoeducación? Una propuesta alternativa con grupos étnicos. Centro de Investigación de la Realidad del Norte, Cuaderno de Investigación Social $\mathrm{N}^{\circ}$ 22, Iquique.

1991 Nuevo escenario, organizaciones no gubernamentales y trabajo educativo alternativo. En Educación y Saber Andino, compilado por J. Podestá y P. Arriaza, pp. 15-28. El Jote Errante, Iquique.

1993 Tradición oral aymara y educación: Buscando nuevos caminos. Revista de Ciencias Sociales 2:7-17.

Podestá, J. y R. Flores y J. Amaro

1989 Uybirmallco. Cerros que nos dan la Vida. Centro de Investigación de la Realidad del Norte, Iquique.

Provoste, P.

1977 Antecedentes Socioeconómicos para el Desarrollo del Sector de Isluga. Universidad del Norte, Centro Isluga, Iquique.

1978a El Altiplano Mirado desde Isluga. Universidad del Norte, Centro Isluga, Iquique.

1978b El altiplano ariqueño. Elementos de comparación con el altiplano de Iquique. Manuscrito en posesión del autor.

1978c Consideraciones para Promover Organizaciones Colectivas en Isluga. Convenio SERPLAC I RegiónUniversidad del Norte.

1979a El sistema altiplano-quebrada. Manuscrito en posesión del autor.

1979b Diferenciación e integración social en el altiplano chileno. América Indígena XLIX, 4:795-811.

1980 Etnia y Comunidad: Los Pueblos del Altiplano de Tarapacá. Tesis de Licenciatura en Sociología, Departamento de Sociología, Universidad del Norte, Antofagasta.

1981 Una sociedad aymara del altiplano chileno (Isluga, provincia de Iquique, I Región de Tarapacá. Desarrollo Rural 1 (1):59-69. 
Quispe, W., G. Espinosa, C. Santoro, H. González y J. Córdova.

1999 Participación de la comunidad Aymara en la conservación y manejo del patrimonio arqueológico de las provincias de Arica y Parinacota. En Patrimonio Arqueológico Indígena en Chile. Reflexiones y Propuestas de Gestión, compilado por X. Navarro, pp. 113-122. Instituto de Estudios Indígenas, Universidad de la Frontera - UNESCO, Temuco.

Ramírez, L.

1977 Rol sexual y estructural de dominación a nivel de la Primera y Segunda Región. Cuaderno de Investigación Social 2:9-13.

Ríos, W.

1990 Continuidad y permanencia de mecanismos de colaboración, solidaridad y participación en la I Región Tarapacá. Diálogo Andino 9:49-57.

Risopatrón, F.

1890 Diccionario Geográfico de las Provincias de Tacna y Tarapacá. Imprenta de la Industria, Iquique.

Risopatrón, L.

1906 La Línea de Frontera en la Puna de Atacama. Imprenta Universitaria, Santiago.

1910 La Línea de Frontera con la República de Bolivia. Imprenta y Litografía Universo, Santiago.

1918 Diario de viaje a las cordilleras de Antofagasta y Bolivia (1903-1904). Revista Chilena de Historia y Geografía XXVII-31:152-184.

1924 Diccionario Geográfico de Chile. Imprenta Universitaria, Santiago.

Rissetti, M.

1977 Descripción de la Actual Estructura de Tenencia de la Tierra en el Valle de Belén. Concepción. Tesis de Licenciatura en Antropología, Departamento de Antropología, Universidad de Concepción, Concepción.

Rivera, F.

1994a Identidad en el Laberinto: La búsqueda del sentido étnico en San Pedro de Atacama. Estudios Atacameños 11:185-194.

1994b La Interrelación Sociedad Mayor/Etnia Atacameña en Torno a la Apropiación Social de Recursos en San Pedro de Atacama. Tesis para optar al título de Antropólogo Social, Departamento de Antropología, Universidad de Chile, Santiago.

1995 El contexto histórico y social del manejo de los recursos agropecuarios en los oasis de San Pedro de Atacama. En Agua, Ocupación y Economía Campesina en la Región Atacameña, editado por P. Pourrut y L. Núñez, pp. 61-77. Universidad Católica del Norte - ORSTOM, Antofagasta.

1997 Procesos de articulación socio-identitarias y reformulaciones étnicas en Atacama. Estudios Atacameños 13:61-73.

1999a Consideraciones en torno a la cuestión étnica en Atacama. Estudios Atacameños 17:33-40.

1999b Construcción y reformulación de la etnicidad atacameña en el norte de Chile. En Construcciones Étnicas y Dinámica Sociocultural en América Latina, editado por K. Koonings y P. Silva, pp. 77-90. Abya-Yala, Quito.

2004 Anti-flexibilización con identidad/alteridad. La cuestión étnica atacameña contemporánea y su contexto neoliberalflexible. Revista de Antropología Experimental 4:1-17.
Rodríguez, G.

2003 El talátur, canto ceremonial de los atacameños. Hombre y Desierto 11:57-72.

Rodríguez Torrent, J.C. y P.A. Miranda Bown

2008 Tiempo industrial y tiempos sociales en María Elena, la última ciudad del salitre. Chungara Revista de Antropología Chilena 40:81-97.

Rodríguez, J., P. Miranda y P. Mege

2002 Etnografía de la Siberia Caliente. Una nota metodológica sobre un estudio en María Elena, el último pueblo salitrero. Estudios Atacameños 22:105-126.

Romero, A.

2003 Arqueología y pueblos indígenas en el extremo norte de Chile. Chungara Revista de Antropología Chilena 35:327335.

Romo, M.

1998a Percepción y Representación del Ambiente en un Grupo de Pastores. Tesis para optar al título de Antropólogo Social, Departamento de Antropología, Universidad de Chile, Santiago.

1998b Pastores del sur andino. Percepción y representación del ambiente. Estudios Atacameños 16:209-231.

Romo, M., V. Castro, C. Villagrán y C. Latorre

1999 La transición entre las tradiciones del desierto y las quebradas altas del Loa Superior. Etnobotánica del valle del Río Grande, II Región, Chile. Chungara Revista de Antropología Chilena 31:319-360.

Rusowsky, D.

2002 Atacameños en Luz y Sombra: Reflejos Entre una Aproximación Televisiva y la Mirada de un Video Comunitario. Tesis para optar al grado de Magíster en Antropología y Desarrollo, Escuela de Postgrado, Facultad de Ciencias Sociales, Universidad de Chile, Santiago.

Ruz, R. y M. Gálvez

2001 La Historia en la Piedra. Putre: Documentos, Memoria y Arquitectura, Siglos XIX-XX. FONDART, Ministerio de Educación, Arica.

2003 Putre. Patrimonio e Historia de una Localidad Precordillerana. Programa Orígenes, Arica.

Salinas, J.

1986 Las áreas silvestres protegidas del Estado y comunidades insertas o aledañas a las mismas. Chungara 16-17:225231.

1987 Descripción de la situación de tenencia de la tierra y sus títulos de domimio en el área oriental del parque Nacional Volcán Isluga. Nota Técnica $\mathrm{N}^{\circ}$ 11, CONAF I Región, Arica.

1989 La comunidad andina y las organizaciones modernas: continuidad, cambio y proyecciones. Documentos de Trabajo, Taller de Estudios Andinos, Arica.

1991 La Comunidad Andina Como una Institución de Tenencia de la Tierra. Tesis para optar al título de Antropólogo Social, Departamento de Antropología, Universidad de Chile, Santiago.

Sánchez, G.

1998 Multilingüismo en el área de San Pedro de Atacama. Lenguas aborígenes atestiguadas por la fitonimia del área de San Pedro de Atacama. Estudios Atacameños 16:171-179.

Sanhueza, C.

1991 Orígenes y Desarrollo de la Arriería Indígena Colonial en Atacama. Siglos XVI-XVIII. Tesis de Licenciatura en 
Historia, Instituto de Historia, Pontificia Universidad Católica de Chile, Santiago.

1992a Estrategias readaptativas en Atacama: la arriería mulera colonial. En Etnicidad, Economía y Simbolismo en los Andes, compilado por S. Arze, R. Barragán, L. Escobari y X. Medinacelli, pp. 363-385. HISBOL/IFEA/SBH-ASUR, La Paz.

1992b Tráfico caravanero y arriería colonial en el siglo XVI. Estudios Atacameños 10:169-182.

2000 "Indio" y "Tributario". Categorías fiscales y discurso social del Estado boliviano del siglo XIX en Atacama. Manuscrito en posesión del autor.

2001 Las poblaciones de la Puna de Atacama y su relación con los estados nacionales. Una lectura desde el Archivo. Revista de Historia Indígena 5:55-82.

2002 En busca del gran mentiroso: Relatos orales, demarcaciones territoriales. El camino del Inca en el despoblado de Atacama. Revista de Historia Indígena 6:97-129.

2004 Medir, amojonar, repartir: Territorialidades y prácticas demarcatorias en el camino incaico de Atacama (II Región, Chile). Chungara Revista de Antropología Chilena 36:483494.

2008 'Indios' de los oasis, 'indios' de la puna. Procesos migratorios y rearticulaciones identitarias en Atacama (Susques, siglos XVIII-XIX). Chungara Revista de Antropología Chilena 40:203-217.

San Román, F

1896 Desierto i Cordilleras de Atacama. 3 Vol. Imprenta Nacional, Santiago.

Santoro, C., L. Núñez, V. Standen, H. González, P. Marquet y A. Torres

1998 Proyectos de irrigación y la fertilización del desierto. Estudios Atacameños 16:321-336.

Schmidt, P.

1980 Antropología y Planificación del Desarrollo de la Educación en el Altiplano Tarapaqueño. Tesis de Licenciatura en Antropología, Departamento de Ciencias Sociológicas y Antropológicas, Universidad de Chile, Santiago.

Serracino, G.

1985 Creencias, organización social y economía en Caspana indígena. La limpia de canales. Actas del Primer Congreso Chileno de Antropología, pp. 399-410. Colegio de Antropólogos de Chile, Santiago.

Serracino, G. y R. Stehberg

1975 Vida pastoril en la precordillera andina. Estudios Atacameños 3:81-99.

Serracino, G., R. Stehberg y G. Liberman

1974 Informe etnobotánico de Guatín (San Pedro de Atacama). Antropología. Nueva Época 1:55-65.

Siarez, E.

1998 Crónicas y relatos históricos de San Pedro de Atacama: 1830-1940. [Sin datos de edición], Antofagasta.

Solc, V.

1969 Los aymaras de las islas del Titicaca. Serie Antropología Social $\mathrm{N}^{\circ} 12$, Instituto Indigenista Interamericano, México.

1975 Casa aymara en Enquelga. Annals of the Náprstek Museum 8:111-146.

Taberna, F.

1968a Los Andes y el Altiplano Tarapaqueños: una Tentativa de Evaluación Geográfica. Tesis para optar al título de Profesor de Estado en Historia y Geografía, Instituto Pedagógico, Universidad de Chile, Santiago.

1968b Algo sobre las comunidades andinas de Tarapacá. Estudios Regionales 1-1:7-19.

1971 Los Andes y el Altiplano Tarapaqueño. Centro de Documentación, Universidad de Chile, Iquique.

1973 El rol de la sociedad andina en el tránsito al socialismo. En Informes de Temas para el Primer Congreso del Hombre Andino, pp. 21-30. Universidad de Chile, IquiqueAntofagasta.

1996 [1968] Isluga, pueblo sagrado. En Homenaje a Freddy Taberna G. Escritos sobre la Sociedad Aymara del Norte de Chile, editado por B. Guerrero, pp. 40-46. El Jote Errante, Iquique.

Tabilo, K.

1997 El héroe y la heroína en relatos populares andinos. Aplicación de un método preestructural. Diálogo Andino 16:9-25.

1999 El Cóndor, el Zorro y la Pastora: Alegorías de lo Femenino y lo Masculino en Relatos de Tradición Oral Aymara. Tesis para optar al título de Antropólogo Social, Departamento de Antropología, Universidad de Chile, Santiago.

Téllez, E.

1984 La guerra atacameña del siglo XVI: Implicancias y trascendencia de un proceso de resistencia indígena en el despoblado de Atacama. Estudios Atacameños 7:399421.

Téllez, E. y O. Silva

1989 Atacama en el siglo XVI. La Conquista Hispana en la Periferia de los Andes Meridionales. Cuadernos de Historia 9:45-69.

Thompson, J.B.

1990 Ideology and Modern Culture: Critical Social Theory in the Era of Mass Communication. Polity, Cambridge.

Tocornal, C.

2004 Panorama etnográfico de la relación entre la medicina tradicional Atacameña y la medicina formal de las comunidades indígenas del Salar de Atacama. Ponencia presentada al Simposio de Antropología Médica, V Congreso Chileno de Antropología, San Felipe.

Torrico, E.

$2000 \mathrm{El}$ manejo del agua de riego en dos regiones andinas: el valle alto de Cochabamba (Bolivia) y la Quebrada de Tarapacá (norte de Chile). En Manos Sabias para Criar la Chacra Andina: Tecnologías Andinas, editado por J. van Kessel y H. Larraín, pp. 215-229. Abya-Yala/IECTA, Quito.

Troll, C.

1958 [1943] Las culturas superiores andinas y el medio geográfico. Traducido por C. Nicholson. Revista del Instituto de Geografía 5:3-55.

Tudela, P.

1992 Transformación Religiosa y Desintegración de la Comunidad Aymara Tradicional en el Norte de Chile. Tesis Doctoral, Holos, Bonn.

1993 Cambio religioso y revitalización de la comunidad entre los aymaras de Arica (1960-1990). Nütram IX (3):15-48. 1994 Chilenización y cambio ideológico entre los Aymaras de Arica (1883-1930). Intervención Religiosa y Secularización. Revista Chilena de Antropología 12:201-231.

2002 El Estado y la sociedad chilena ante los aymaras de Tarapacá (I Región de Chile): factores y consecuencias de su integración entre 1930 y 1973. Documento de Trabajo $\mathrm{N}^{\circ} 24$, Comisión Verdad Histórica y Nuevo Trato, Santiago. 
Uhle, $\mathrm{M}$.

1918 Los Aborígenes de Arica y el Hombre Americano. Imprenta de la Aurora, Arica.

1919 La arqueología de Arica y Tacna. Boletín de la Sociedad Ecuatoriana de Estudios Históricos Americanos III (7-8):148.

1922 Fundamentos Étnicos y Arqueología de Arica y Tacna. Imprenta de la Universidad Central, Quito, Ecuador.

Uribe, M. y L. Adán

2003 Arqueología, patrimonio cultural y poblaciones originarias: reflexiones desde el desierto de Atacama. Chungara Revista de Antropología Chilena 35:295-304.

Vaïsse, E., F. Hoyos y A. Echeverría

1896 Glosario de la Lengua Atacameña. Imprenta Cervantes, Santiago.

Valdés, $\mathrm{X}$.

1992 Los aymaras y sus perspectivas de desarrollo en el contexto de la transición democrática. Documentos de Trabajo, EFDES, Santiago.

Valenzuela, B.

1969-70 Epítome etnográfico de la cuenca del río Salado. Provincia de Antofagasta, Chile. Boletín de Prehistoria 2-3:75-99.

van der Zee, L

1989 Onderwijs, identiteit en het recht op een eigen cultuur: de Aymara's van Noord-Chili. Doctoral Dissertation, Vrije Universiteit Ámsterdam, Ámsterdam.

van Kessel, J.

1974a El floreo en Lirima Viejo, provincia de Tarapacá, Chile. Norte Grande I (1):34-44.

1974b Los conjuntos de bailes religiosos del Norte Grande. Análisis del censo practicado en 1973. Norte Grande I (2):211-216.

1975a Supervivencias prehispánicas en un verso religioso popular del norte de Chile. Norte Grande I (3-4):427436.

1975b La Imagen Votiva en la Cosmovisión del Hombre Andino Contemporáneo. Cuaderno de Investigación Social 1:2-9.

1976 La pictografía rupestre como imagen votiva (un intento de interpretación antropológica). En Homenaje al Dr. Gustavo Le Paige s.j., pp. 227-244. Universidad del Norte, Antofagasta.

1977a La estructura de la economía colonial en la antigua provincia de Tarapacá. Actas del VII Congreso de Arqueología de Chile. Altos de Vilches, 27 de octubre al 1 de noviembre de 1977, Vol. 2, pp. 365-392. Kultrún, Santiago.

1977b La fiesta patronal o fiesta del pueblo en la comunidad aymara. Teología y Vida. XVIII (2-3):145-160.

1978-1979 Muerte y ritual mortuorio entre los aymaras. Norte Grande 6:77-91.

1980a Holocausto al Progreso. Los Aymaras de Tarapacá. Tesis Doctoral, CEDLA, Vrije Universiteit Ámsterdam, Ámsterdam.

1980b Ecología y orientación. Problemas de identidad cultural de los aymaras chilenos contemporáneos. Chungara 6:137-144.

1981 Danzas y estructuras sociales en los Andes. Instituto de Pastoral Andina, Cusco.

1983 Ayllu y ritual terapéutico en la medicina andina. Chungara 10:165-176.

1984 Los bailes religiosos del norte chileno como herencia cultural andina. Chungara 12:125-134. 1985a Los aymaras contemporáneos de Chile (1879-1985); su historia social. Centro de Investigación de la Realidad del Norte, Cuaderno de Investigación Social $\mathrm{N}^{\circ} 19$, Iquique.

1985b La lucha por el agua de Tarapacá; la visión andina. Chungara 14:141-155.

1985c Medicina Andina. Centro de Investigación de la Realidad del Norte (CIREN), Iquique.

1985d Tecnología Médica Andina. Centro de Investigaciones de la Realidad del Norte (CIREN), Iquique.

1987a El llamado 'repunte económico' en la Precordillera de Tarapacá; el caso de Sibaya. Centro de Investigación de la Realidad del Norte, Cuaderno de Investigación Social $\mathrm{N}^{\circ} 25$, Iquique.

1987b Lucero del Desierto. Centro de Investigación de la Realidad del Norte (CREAR), Iquique.

1988a Salud en el mundo aymara de Chile. Enfoques en Atención Primaria 3 (2):17-24.

1988b Tecnología aymara: un enfoque cultural. Hombre y Desierto 2:58-88.

1989a La Iglesia Católica entre los Aymaras. Rehue, Santiago.

1989b Ritual de producción y discurso tecnológico. Chungara 23:73-91.

1989c Los espacios andino y urbano y su articulación: validez de los conceptos. Allpanchis 33:135-159.

1990a Los Aymaras bajo el Régimen militar de Pinochet (1973-1990). Centro de Investigación de la Realidad del Norte, Cuaderno de Investigación Social No 29, Iquique.

$1990 \mathrm{~b}$ ¿Renace el Aymara en Chile? Boletín del Instituto de Estudios Aymaras Serie 2, 36:49-66.

1990c ¿Renace el aymara en Chile? Nütram VI (3):61-76.

1990d Tecnología y ecología en los Andes: ¿cómo funciona la tecnología simbólica? En Desarrollo Andino y Cultura Aymara en el Norte de Chile, editado por H. González y B. Guerrero, pp. 76-97. El Jote Errante, Iquique.

1990e Tecnología aymara: un enfoque cultural. En Tecnología Andina. Una Introducción, editado por J. Earls, E. Grillo, H. Araujo y J. van Kessel, pp. 143-226. Hisbol, La Paz.

1990f La Huilancha al Señor: consultando a la teología sobre un rito aymara-cristiano. Nütram VI (4):69-78.

1991a Ritual de Producción y Discurso Tecnológico Andino. CIDSA, Puno.

1991b Los aymaras contemporáneos de Chile (1879-1990). Su historia social. Diálogo Andino 10:47-72.

1991c Los Aymaras bajo el Régimen Militar de Pinochet (1973-1990). El Jote Errante, Iquique.

1991d La organización aymara del espacio: un espacio para la etno-educación. En Educación y Saber Andino, compilado por J. Podestá y P. Arriaza, pp. 95-113. El Jote Errante, Iquique.

1992a Holocausto al Progreso. Los Aymarás de Tarapacá. Segunda edición aumentada. Hisbol, La Paz.

1992b Problemas del desarrollo Andino: El modelo de la escasez como motor del desarrollo económico. Cuadernos de Investigación en Cultura y Tecnología Andina $\mathrm{N}^{\circ} 4$, IECTA, Iquique.

1992c Cuando Arde el Tiempo Sagrado. Hisbol, La Paz. 1992d Aica y la Peña Sagrada. El Jote Errante, Iquique. 1992e La organización tempo-espacial del trabajo entre los aymaras de Tarapacá: la perspectiva mitológica. En Etnicidad, Economía y Simbolismo en los Andes. II Congreso Internacional de Etnohistoria, Coroico, compilado por S. Arze, R. Barragán, L. Escobari y X. Medinacelli, pp. 267297. HISBOL/IFEA/SBH-ASUR, La Paz. 
1992f Tecnología aymara: un enfoque cultural. En $L a$ Cosmovisión Aymara, editado por H. van den Berg y N. Schiffers, pp. 187-219. La Paz, Hisbol.

$1992 \mathrm{~g} \mathrm{El}$ pago a la tierra, porque el desarrollo lo exige. Allpanchis 40:201-217

1993a Tecnología andina: Un enfoque cultural. CIDSA, Cuadernos de Investigación en Cultura y Tecnología Andina $\mathrm{N}^{\circ}$ 3, Puno.

1993b El tramposo engañado: El zorro en la cosmovisión andina. Revista de Ciencias Sociales 3:25-34.

1993c Ojo de Cóndor. Visión Aymara de Tiempo y Espacio en Tarapacá, Chile. Vol. I. CIDSA, Tocopilla.

1993d Ojo de Cóndor. Visión Aymara de Tiempo y Espacio en Tarapacá, Chile. Vol. II. CIDSA, Tocopilla.

1994 El zorro en la cosmovisión andina. Chungara 26:233242.

1996a Los aymaras contemporáneos de Chile. En Etnografía. Sociedades indígenas Contemporáneas y su Ideología, editado por J. Hidalgo, V. Schiappacasse, H. Niemeyer, C. Aldunate y P. Mege, pp. 47-68. Andrés Bello, Santiago.

1996b La Cosmovisión Aymara. En Etnografía. Sociedades Indígenas Contemporáneas y su Ideología, editado por J. Hidalgo, V. Schiappacasse, H. Niemeyer, C. Aldunate y P. Mege, pp. 169-198. Andrés Bello, Santiago.

1997a Ritual de reproducción y discurso tecnológico andino. IECTA, Cuadernos de Investigación en Cultura y Tecnología Andina $\mathrm{N}^{\circ}$ 5, Iquique.

1997b Antropología andina. IECTA, Cuadernos de Investigación en Cultura y Tecnología Andina $\mathrm{N}^{\circ} 10$, Iquique.

1999 El ritual mortuorio de los aymaras de Tarapacá como vivencia y crianza de la vida. En Los Vivos y los Muertos. Duelo y Ritual Mortuorio en los Andes, editado por J. van Kessel, pp. 185-209. IECTA, Iquique.

2000a La empresa salitrera: el primer milagro económico chileno y el último capítulo de la historia de la comunidad aymara en Tarapacá (Siglos XIX - XX). IECTA, Cuadernos de Investigación en Cultura y Tecnología Andina, $\mathrm{N}^{\mathrm{o}} 15$, Iquique.

2000b La tecnología simbólica en la producción agropecuaria andina. En Manos Sabias para Criar la Chacra Andina: Tecnologías Andinas, editado por J. van Kessel y H. Larraín, pp. 35-57. Abya-Yala/IECTA, Quito.

2001 El ritual mortuorio de los aymara de Tarapacá como vivencia y crianza de la vida. Chungara Revista de Antropología Chilena 33:221-234.

2003 La economía andina de crianza; actores y factores metaeconómicos. Revista de Ciencias Sociales 13:71-78.

van Kessel, J. y D. Condori

1992 Criar la Vida: Trabajo y Tecnología en el Mundo Andino. Vivarium, Santiago.

van Kessel, J. y B. Guerrero

1987 Sanidad y salvación en el altiplano chileno. Del yatiri al pastor. Centro de Investigación de la Realidad del Norte, Cuaderno de Investigación Social $\mathrm{N}^{\circ} 21$, Iquique.

van Kessel, J. y H. Larraín Barros, editores

2000 Manos Sabias para Criar la Chacra Andina: Tecnologías Andinas. Abya-Yala/IECTA, Quito.

Varela, V.

1992 De Toconce "Pueblo de Alfareros" a Turi "Pueblo de Gentiles”. Tesis para optar al título de Antropólogo Social, Departamento de Antropología, Universidad de Chile, Santiago.
2002 Enseñanzas de alfareros toconceños: tradición y tecnología en la cerámica. Chungara Revista de Antropología Chilena 34:225-252.

Vargas, P.

1979 Isluga: Una Problemática para el Desarrollo. Tesis de Licenciatura en Antropología, Departamento de Ciencias Sociológicas y Antropológicas, Universidad de Chile, Santiago.

Villagrán, C. y V. Castro

1997 Etnobotánica y manejo ganadero de las vegas, bofedales y quebradas en el Loa Superior, Andes de Antofagasta, Segunda Región, Chile. Chungara 29:275-304.

Villagrán, C., V. Castro y G. Sánchez

1998 Etnobotánica y percepción del paisaje en Caspana (Provincia de El Loa, Región de Antofagasta, Chile: ¿Una cuña atacameña en el Loa Superior? Estudios Atacameños 16:107-170.

Villagrán, C., V. Castro, G. Sánchez, F. Hinojosa y C. Latorre 1999 La tradición altiplánica: estudio etnobotánico en los Andes de Iquique, Primera Región, Chile. Chungara Revista de Antropología Chilena 31:81-186.

Villagrán, C., V. Castro, G. Sánchez, M. Romo, C. Latorre y L. Hinojosa

1998 La tradición surandina del desierto: Etnobotánica del área del Salar de Atacama (Provincia de El Loa, Región de Antofagasta, Chile). Estudios Atacameños 16:7-105.

Villagrán, C., M. Romo y V. Castro

2003 Etnobotánica del sur de los Andes de la Primera Región de Chile: Un enlace entre las culturas altiplánicas y las de quebradas altas del Loa Superior. Chungara Revista de Antropología Chilena 35:73-124.

Villalobos, S.

1974 La mita de Tarapacá en el siglo XVIII. Norte Grande I (3-4):301-312.

1979 La Economía de un Desierto. Tarapacá Durante la Colonia. Nueva Universidad, Santiago.

Villaseca, M.

1998 Percepción, desecación y revitalización cultural. Estudios Atacameños 16:233-250.

2000 Dos Historias, un Paisaje: Transformación y Persistencia en el Alto Loa. Tesis para optar al título de Antropólogo Social, Departamento de Antropología, Universidad de Chile, Santiago.

Wachtel, N.

1992 Note sur le problème des identités collectives dans les Andes méridionales. L'Homme 122-124, XXXII (2-3-4):3952.

Wali, A.

1989 Etnicidad y desarrollo en Chile. La labor de TER y SOPRODER. Informe de Evaluación para Interamerican Foundation. Manuscrito en posesión del autor.

1990 En comunión con la tierra. Etnicidad y desarrollo en Chile. Desarrollo de Base 14 (2):12-20.

Wormald, A.

1966 El Mestizo en el Departamento de Arica. Universidad del Norte, Santiago.

1968 Frontera Norte. Orbe, Santiago.

1972 Historias Olvidadas del Norte Grande. Universidad del Norte, Arica.

Zapata S., C.

2004 Atacameños y aymaras: el desafío de la 'verdad histórica'. Estudios Atacameños 27:169-187. 
2007 Memoria e historia: el proyecto de una identidad colectiva entre los aymaras de Chile. Chungara Revista de Antropología Chilena 39:171-183.

Zapata T., C.

1999 Las Voces del Desierto: la Reformulación de las Identidades de los Aymaras en el Norte de Chile. Tesis de
Licenciatura en Etnología, Escuela Nacional de Antropología e Historia, México.

2001 Las Voces del Desierto: Identidad Aymara en el Norte de Chile. Ediciones RIL-DIBAM, Santiago.

Zapater, $\mathrm{H}$.

1976-1977 Cinco relaciones sobre San Pedro de Atacama. Norte Grande 5:49-63.

\section{Notas}

1 Como señala uno de ellos, el desierto era "uno de los cinco principales campos de exploración en los tiempos históricos" (Bowman 1924; traducido en 1942).

2 Aunque para un período anterior al tratado, es importante mencionar las observaciones realizadas por William Bollaert durante la primera mitad del siglo XIX, cuyos aportes específicos sobre el área se han publicado aparte (Bollaert 1975 [1860], 1981 [1851-1854-1860]).

3 Para este mismo período, también se pueden considerar un trabajo de Earl Hanson (1926) sobre los atacameños, publicado en Norteamérica, y el capítulo sobre los atacameños de Wendell Bennett (1946) del Handbook of South American Indians, que combinan la información arqueológica con la etnográfica disponible.

4 Cúneo-Vidal inicia sus publicaciones en los años de 1910. Sus trabajos más importantes para la zona norte de Chile se encuentran reunidos en los volúmenes 1, 4, 5 y 6 de sus Obras Completas, que se publican en 1977.

5 Para una revalorización de Cúneo-Vidal como pionero en la apertura de los estudios etnohistóricos regionales véase Galdames 2009.

6 Para un mayor desarrollo de estas ideas véase Gundermann 2003b.

7 Obra publicada con la colaboración de Raúl González y un apéndice con un estudio de aguas de Fernando Oberhauser; también incluye una segunda parte con un estudio antropológico físico de Fidel Jeldes; y una tercera parte de G. Mostny con apuntes sobre el cunza (Mostny 1954). G. Mostny, austriaca de origen judío, doctorada en egiptología, llega a Chile escapando de la convulsionada situación europea. Sus principales aportes corresponden al ámbito de la arqueología de nuestro país.

8 En el marco de un convenio de intercambio entre la Universidad de Chile y la Universidad Carolina de Praga que operó entre 1965 y 1973. Esta misión también fue integrada por Milan Stuchlik, que realizó sus estudios entre los mapuche.

9 También circula, pero incompleto, un informe evacuado a las autoridades de la Universidad de Chile sobre localidades de la precordillera de Arica y el altiplano de Iquique. V. Solc había estado antes en Bolivia y trabajado con los aymaras del lago Titicaca (1969).

10 B. Bittmann se forma en Europa, pero sus intereses de investigación eran americanistas y había realizado previamente estudios sobre códices en México. Tiene también aportes sobre el uso de los recursos en Atacama (Bittmann 1988) y fue autora, junto a Le Paige y Núñez, del texto Cultura Atacameña (Bittmann et al. 1978) y coordinó el Simposio sobre esta misma cultura del $44^{\circ}$ Congreso Internacional de Americanistas de Manchester (1982).
11 El profesor L. Álvarez formó parte del grupo pionero de arqueólogos ariqueños, junto a las figuras de Percy Dauelsberg y Guillermo Focacci. Como docente de la carrera de historia y geografía, primero de la sede Arica de la Universidad de Chile y luego de la Universidad de Tarapacá, dirigió numerosas tesis de alumnos sobre aspectos de la zona andina local. Aparte de sus trabajos arqueológicos, entre sus principales aportes se cuentan su tesis de magistratura sobre la etnopercepción andina del espacio en valles dulces y salados (L. Álvarez 1990), que ha dado origen a varios artículos (L. Álvarez 1991, 1992, 1997a). Destaca también su aporte en iniciativas de elaboración de una historia de la ciudad (Galdames et al. 1981), además de varios artículos sobre temas andinos o historia regional (L. Álvarez 1987, 1997b, 1998).

12 Todos los trabajos de Freddy Taberna se encuentran reunidos en Guerrero (editor) 1996.

13 Estos planteamientos se encuentran en el informe al Simposio 4: "El rol de la sociedad andina en el tránsito al socialismo" del Primer Congreso del Hombre Andino, cuya redacción final estuvo a cargo de Freddy Taberna y la Comisión Organizadora de ese evento (Taberna 1973).

14 En esta misma revista, Horacio Zapater (1976-1977) publica documentación histórica sobre San Pedro de Atacama.

15 Las primeras publicaciones de J. Hidalgo sobre la historia indígena regional se inician en 1978. Previamente S. Villalobos (1974) escribe sobre la mita de Tarapacá en el S. XVII y luego su libro sobre la economía del desierto tarapaqueño durante la colonia (Villalobos 1979). Por estos mismos años, el historiador boliviano Fernando Cajías (1977) publica su obra sobre la provincia de Atacama entre 1825 y 1842.

16 Aparte de los aportes publicados en la revista Norte Grande, ya citados, van Kessel también publica otros trabajos aprovechando la información histórica o etnográfica de las comunidades de Cultane y Lirima reunida para la elaboración de su tesis doctoral (van Kessel 1976, 1977a, 1977b).

17 Murra retoma los aportes del geógrafo Carl Troll (1958) y los avances de la antropología social con sentido histórico anglosajón. Sus trabajos, dispersos en distintas revistas y publicaciones, se compilaron finalmente en 1975, mientras que su tesis doctoral inédita sobre la organización económica del estado Inca fue publicada en 1978.

18 En esta misma perspectiva se ubica su conocida y demoledora crítica (Platt 1975b) a Roberto Hernández (1974), quien sostenía una visión de la desintegración de la comunidad tradicional en Chiuchiu. El mismo enfoque fue aplicado también por este último en un trabajo sobre Toconce (Hernández et al. 1975).

19 Este mismo grupo de estudiantes creó en Antofagasta el Centro de Investigaciones de la Realidad del Norte (CIREN), que posteriormente se trasladará a Iquique y se transformará 
en uno de los principales organismos no gubernamentales. Bajo el alero de este Centro, ligado a la carrera de sociología de la Universidad del Norte, editaron los dos primeros números de la revista Cuadernos de Investigación Social, donde aparecen sus primeros trabajos con avances de los temas que abordarán en sus tesis o de los que desarrollaban por encargo de van Kessel que elaboraba su propia tesis doctoral (Pérez 1975, 1977; González y Ramírez 1975; Ramírez 1977; Guerrero 1975, 1977; Podestá 1975, 1976). Esta revista recibió también el aporte del mismo van Kessel (1975b). Algunos de ellos también publicaron trabajos en la revista Tambo de esa misma casa de estudios, como González (1979).

20 Junto a ellos se ubica Julián González, perteneciente al mismo grupo de estudiantes, pero que presentará recién en 1991 su tesis sobre el tema de los jóvenes migrantes andinos en Iquique, los que presenta como "hijos de la desintegración".

21 No son ajenas las tensiones de ese momento con los países vecinos, que coincidían con el centenario de la Guerra del Pacífico.

22 En el Centro Isluga, creado en 1975, junto o después de las figuras señeras de Gabriel Martínez y Verónica Cereceda, también participarán, en diversos momentos y grados: la socióloga Patricia Provoste, la antropóloga Marietta Ortega, los arqueólogos Olaf Olmos y Julio Sanhueza, los agrónomos Italo Lanino y Luis Tapia e Ignacio Albornoz.

23 Las propuestas y acción de las ONGs fueron objeto de tesis de grado, como la de María Arratia (1991), antropóloga chileno-canadiense, y trabajos evaluativos encargados por las mismas agencias de cooperación, como los de Alaka Wali (1989 y 1990) y de Ximena Valdés (1992), donde si bien la mayor parte de la información de caracterización proviene de fuentes secundarias, constituyen un valioso instrumento de documentación de la actividad de estos organismos durante este período.

24 También para la zona atacameña, en estos años Serracino (1985) publica un trabajo sobre los aspectos ceremoniales y económicos de la limpia de canales en Caspana, cuando trabajaba para la Corporación Cultural de la Municipalidad de Calama.

25 Con excepción del estudio de Julián González (1987), que como discípulo de J. van Kessel definió a los jóvenes aymaras urbanos como los "hijos de la desintegración cultural" (1987 y su tesis de grado (1991), sólo se pueden mencionar otro de H. González (1990) sobre la complementariedad campo-ciudad en una pequeña comunidad cercana a Arica y, principalmente, los de S. González $(1987,1989)$ que, siguiendo una línea de investigación histórica sobre la pampa salitrera, incorporó a sus análisis el elemento indígena que trabajó o estuvo conectado a las oficinas.

26 Refugiada en los museos y en problemáticas muy alejadas en el pasado, la arqueología tuvo mejor suerte. Lautaro Núñez (1996) ha realizado un recuento de lo acaecido durante el período de dictadura con la antropología en la Universidad del Norte.

27 También en un temprano trabajo de análisis censal para el período 1907-1970 en el área de El Loa (Berenguer et al. 1973).

28 Aparte del de Aldunate, la revista Chungara, Revista de Antropología Chilena $\mathrm{N}^{\mathrm{o}} 14$ publica varios trabajos sobre la presión regional sobre las aguas de las comunidades indígenas del norte del país (Bernhardson 1985b; Hidalgo 1985a; Núñez 1985; van Kessel 1985b).

29 Como resultado de este proyecto se publicaron varios documentos de trabajo sobre el tema de la educación entre los aymaras, que circularon en versión mimeografiada (Gundermann 1984a, 1985a-c; Gundermann y Chipana 1986).

30 Destacan los trabajos de Galdames $(1987,1990)$ sobre la piedra en la mentalidad andina. Además de los aportes ya citados de Álvarez, de esta misma unidad académica Waldo Ríos (1990) también publica un trabajo sobre la continuidad de los mecanismos de solidaridad andinos.

31 Ambos realizan también trabajos en colaboración con arqueólogos (J. Hidalgo et al. 1982; Hidalgo y Focacci 1986; Berenguer y Martínez 1986, 1989). J. Hidalgo también participa en esos años como coeditor de la Prehistoria de Chile (Hidalgo et al. 1989).

32 Una línea paralela de historia del arte indígena colonial es liderada por Luis Briones, específicamente respecto de la pintura y arquitectura de las iglesias de las comunidades indígenas de la Región de Tarapacá (Briones y Vilaseca 1983; Briones et al. 1989; Chacama et al. 1988-89; Chacama et al. 1992).

33 El organismo estatal creado por el primer gobierno de la Concertación de Partidos por la Democracia para canalizar la política estatal hacia los pueblos indígenas.

34 El primero, editado por el mismo van Kessel (1999), contiene también los aportes de A. Aláez (1999), M. Escalante (1999) y de M. Ortega (1999) para el caso andino chileno (todos los trabajos de este libro fueron republicados el año 2001 en Chungara, Revista de Antropología Chilena vol. 33, $\mathrm{N}^{\circ} 1$ ). El segundo, editado en conjunto con $\mathrm{H}$. Larraín (van Kessel y Larraín 2000), incluye también los aportes de J. Herrera (2000) sobre los derechos de agua en Tarapacá en los S. XVII-XIX y de E. Torrico (2000) que compara la situación actual del manejo del agua en la quebrada tarapaqueña con lo que ocurre en Cochabamba.

35 "La alegría ya viene" fue el eslogan utilizado por la Concertación de Partidos por la Democracia en la campaña plebiscitaria de 1988.

36 Por ejemplo, P. Arriaza ha seguido realizando algunos trabajos sobre experiencias de colonización de la Pampa del Tamarugal (2002a) y el impacto de los proyectos mineros entre los aymaras (2002b), los que se mantienen inéditos. Otros son los casos de una variedad de informes a instituciones públicas elaborados en el marco de proyectos, los que permanecen inéditos.

37 Una mención aparte merecen los aportes de un grupo de investigadores de la Universidad de Antofagasta, que a partir de los años noventa realizan una serie de publicaciones que se enmarcan más bien en un plano de rescate y divulgación general del patrimonio cultural de las comunidades indígenas del área atacameña, incluidas su historia y su lengua (Bustos 1999, 2000; Bustos y Lehnert 1999, 2000; Gómez 1995; Gómez et al. 1998; Gómez y Bustos 1999; Gómez y Siarez 1995; Lehnert 1994, 1998, 1999b, 2000; Lehnert et al. 1997). Destacan Domingo Gómez que, desde su época de profesor rural en la zona, ha contribuido con recopilaciones de relatos orales $(1976,1979,1980,1982,1993,1994)$ y con un trabajo sobre la alimentación (1981-1982); y Roberto 
Lehnert con sus aportes sobre la lengua kunza, la literatura oral y otros aspectos de la cultura atacameña $(1976,1978$, 1982, 1987, 1988, 1993, 1995, 1999a, 1999c, 2002). Otros autores ajenos a la disciplina que trabajan respecto de la zona de Atacama son Reinaldo Lagos et al. (1982, 1988, 1995-1996) sobre creencias y ritos en Río Grande, Ana Matus (1993-1994) sobre la ceremonia de la limpia de canales en Caspana y Gustavo Rodríguez (2003) sobre el canto ceremonial del talátur.

38 El trabajo de S. González (2009) sobre la presencia boliviana en la producción salitrera, incluido en este mismo número, forma parte también de este mismo esfuerzo.

39 Sobre este tema también se puede consultar un trabajo de Xavier Albó (2000), donde aborda la situación en Bolivia, Perú y Chile.

40 Sus trabajos incluidos en este mismo número son ejemplo de ello (Carrasco y Gavilán 2009; Gavilán 2009).

41 Victoria Castro ha trabajado, además, el tema de la evangelización temprana y la religión atacameña (Castro 1991, 1993, 1997), la adoración a las montañas (Castro y Aldunate 2003), las ceremonias tradicionales (Castro y Varela, editoras 1994), la tradición oral (Castro y Varela 1992), la dinámica de las identidades (Castro 1998, 2001), la ocupación del espacio (Castro et al. 2004). Con José Luis Martínez es autora de la síntesis etnográfica del pueblo atacameño (Castro y Martínez 1996). También lideró un proyecto sobre etnobotánica entre aymaras y atacameños, que ha entregado importantes publicaciones (Romo et al. 1999; Villagrán y Castro 1997; Villagrán, Castro y Sánchez 1998; Villagrán, Castro, Sánchez, Romo, Latorre e Hinojosa 1998; Villagrán, Castro, Sánchez, Hinojosa y Latorre 1999; Villagrán, Romo y Castro 2003), incluido su último libro sobre ciencia indígena en los Andes (Castro y Villagrán 2004).

42 Asimismo, las nuevas generaciones de arqueólogos han empezado a cuestionar y replantear su quehacer en términos de la interacción con las comunidades indígenas contemporáneas que han empezado a reclamar sus derechos sobre el patrimonio cultural existente en su territorio (Ayala et al. 2003; Bravo 2003; Carrasco et al. 2003; Jiménez y Seguel 2003; Jofré 2003a, 2003b; Romero 2003; Uribe y Adán 2003).

43 Estos trabajos fueron publicados en la revista Estudios Atacameños $\mathrm{N}^{\circ} 16$, que incluye, además, trabajos de etnobotánica en Caspana (Villagrán, Castro y Sánchez 1998); sobre evidencias de mutilingüismo en la fitonimia de San Pedro de Atacama (Sánchez 1998); sobre pastoralismo y transformaciones sociales (Gundermann 1998a, 1998b, 1998c); y sobre proyectos de irrigación en el desierto (Santoro et al. 1998).

44 Milka Castro ha liderado varios proyectos, como el Catastro de Vegas y Bofedales I y II Regiones, financiado por la Dirección General de Aguas; o el de Uso y apropiación cultural de la tierra por las comunidades aymaras en la provincia de Parinacota, financiado por la CONADI.

45 Esta última también ha publicado un trabajo sobre organización social y representación espacial en la misma comunidad de Cariquima (P. Beltrán 2002).

46 C. Echeverría (1998b) también publica un trabajo sobre la división sexual del trabajo y el matrimonio.

47 El tema de los derechos ancestrales de las comunidades indígenas sobre el agua ha recibido también el aporte de algunos abogados, como Manuel Cuadra (1999, 2000, 2001) que reside en la localidad de San Pedro.

48 Entre la intelectualidad indígena aymara y atacameña destacan algunos trabajos de Juan Álvarez Ticuna (1987, 1989a, 1989b, 1990, 1991, 1995, 2000, 2002), Cornelio Chipana (1986, 1989, 1995, 1996a, 1996b, 2000), Manuel Escalante (1999, 2001), Emilio Fernández Canque (2001), Pedro García (2002), Bartolo Mamani y Javier Vilca (1989); Manuel Mamani (1982, 1985, 1988-1989, 1989, 1994, 1996, 1999, 2002; Mamani y Luque 1997); Walter Quispe (Quispe et al. 1999), Eva Siarez (1998; Gómez y Siarez 1995).

49 Los principales trabajos de la obra de J. Hidalgo son incluidos en su reciente libro sobre la historia andina en Chile (Hidalgo 2004). Una muestra de la continuidad de su rescate y análisis de fuentes documentales de archivos se puede observar en su trabajo incluido en este mismo número sobre la obra de O’Brien (Hidalgo 2009).

50 A fines de los años noventa un grupo de estudiantes de la carrera de historia de la Universidad de Tarapacá, hoy egresados, forman el Taller de Investigaciones Culturales Tincu, que edita desde 1997 la revista Percepción, que incluye algunos aportes referidos al mundo andino, principalmente de Alberto Díaz, Carlos Mondaca, Rodrigo Ruz y Macarena Gálvez. Se trata de trabajos de iniciación a la investigación sobre aspectos actuales o pasados, para lo cual utilizan fuentes regionales, principalmente de los archivos de la subdelegación de Putre y de la gobernación de Arica que mantiene esta universidad. Algunos de ellos han publicado textos de difusión de historias de comunidades con el auspicio de programas de apoyo al desarrollo de la cultura (Díaz et al. 2002; Gálvez y Ruz 2004; Ruz y Gálvez 2001, 2003).

51 Dentro de este nuevo grupo de investigadores destacan los aportes de C. Andaur, M. Araya, P. Arévalo, V. Briones, L. Castro, N. Castro, S. Dueñas, A. Durston, A.M. Farías, C. Figueroa, V. Gallardo, F. Henríquez, J. Herrera, V. Manríquez, M. Marsilli, N. Martínez, C. Odone y C. Sanhueza (Andaur 2004; Araya 2003; Arévalo 1993; Briones 1999; L. Castro, 1999 y 2004; Castro y Figueroa 2001-2002, 2005; Castro e Hidalgo 1999, 2002; Dueñas 2003 y 2005; Durston e Hidalgo 1999; Figueroa 2001; Henríquez 1997-1998 y 2003; Herrera 1991, 1998 y 2000; Hidalgo y Castro 1997 y 1999; Hidalgo y Durston 1998; Hidalgo, Marsilli y Ruiz 1990; Hidalgo, Marsilli, Santoro y Correa 1990; Hidalgo et al. 1991; Hidalgo et al. 1992; Hidalgo et al. 1997; Hidalgo et al. 2004; Hidalgo y Manríquez 1992; Manríquez 19992000; Manríquez y Sánchez 2003; Marsilli e Hidalgo 1992; Martínez et al. 1991; Martínez et al. 2002; Odone 1994, 1995; Ortiz 1995, 1998; Sanhueza 1991, 1992a, 1992b, 2000, 2001, 2002, 2004, 2008). También en el marco de un proyecto dirigido por J. Hidalgo, L. Galdames (1999) ha publicado un trabajo sobre el ámbito "local" como perspectiva de análisis para los pueblos andinos de la región.

52 Esta preocupación sigue vigente, como lo muestra el trabajo sobre propiedad de la tierra e identidades colectivas incluido en este mismo número (González y Gundermann 2009).

53 Un avance en este sentido lo constituye el trabajo de Carrasco y Gavilán (2009) publicado en este mismo número de la revista. 
54 Al punto que para N. Wachtel (1992), ello constituye el núcleo de la identidad cultural andina.

55 Para ser justos, algunos de estos problemas son extensibles a otros campos de la antropología social regional; y también, de manera más amplia, a las otras disciplinas antropológicas: la etnohistoria, la arqueología y la bioantropología.

56 Para el caso atacameño los trabajos de Chamorro y Tocornal (2004 y 2005), de Tocornal (2004) y de Pérez (2003 y 2005), para el aymara los de Pedrero (1997, 2002, 2004; Muñoz y Pedrero 2002) y A. M. Carrasco (2003b, 2005a-c; Carrasco y Cofré 2001; Carrasco y Gavilán 2004, 2005) y Egaña (2005).
57 Para el caso aymara de la Región de Tarapacá se cuenta con un trabajo de A. Díaz (1997) sobre la cumbia andina. 58 A lo que ha contribuido la propia antropología.

59 Cabe recordar que en esta diversa construcción de conocimiento no sólo han participado etnógrafos, por lo que se ha ampliado la cobertura de atención para incorporar otras disciplinas y profesionales cuyos intereses convergen sobre esos objetos y contribuyen a su creación.

60 Hay espacio para otras antropologías regionales como, por ejemplo, una antropología de la realidad histórico-cultural y actual de la minería del norte del país (véanse en este sentido los trabajos de Rodríguez et al. 2002 y Rodríguez y Miranda 2008). 


ANDROS IMPRESORES

www.androsimpresores.cl 
